Aus der Abteilung Allgemein- und Viszeralchirurgie

(Prof. Dr. med. H. Becker)

im Zentrum Chirurgie

der Medizinischen Fakultät der Universität Göttingen

\title{
Induktion und Reparatur von DNA-Doppelstrangbrüchen nach kombinierter Einwirkung von Cisplatin und Bestrahlung auf eukaryote Zellen
}

\author{
INAUGURAL-DISSERTATION \\ zur Erlangung des Doktorgrades \\ der Medizinischen Fakultät \\ der Georg-August-Universität zu Göttingen
}

vorgelegt von

Friederike Wanke

aus Hildesheim

Göttingen 2010 
Dekan:

I. Berichterstatterin:

II. Berichterstatter/in:

III. Berichterstatter/in:
Prof. Dr. med. C. Frömmel

PD Dr. med. S. König

Prof. Dr. rer. nat. P. Virsik-Köpp

Tag der mündlichen Prüfung: $\quad$ 09. August 2010 


\section{Inhaltsverzeichnis}

1 Einleitung........................................................................................................................................... 1

1.1 Onkologische Epidemiologie und Therapie ..................................................... 1

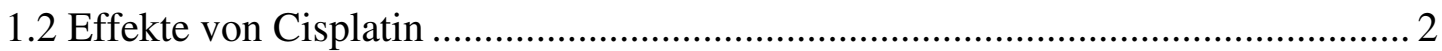

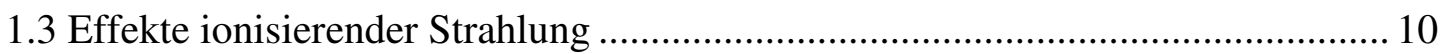

1.4 Kombination von Cisplatin und Bestrahlung.................................................. 12

1.5 Mutante rad54-3 der Hefe Saccharomyces cerevisiae als Modell ...................... 13

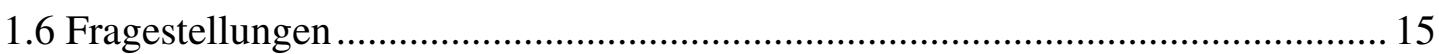

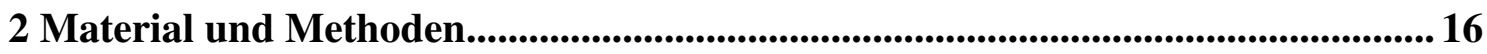

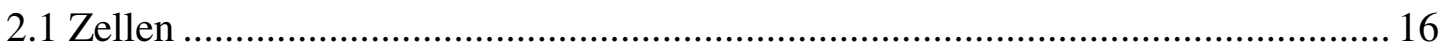

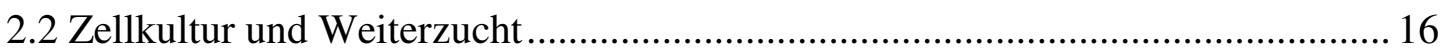

2.3 Bestimmung des Zelltiters und Waschen der Hefezellen .................................... 16

2.4 Behandlung der Hefezellen mit Cisplatin und Akkumulation von DNA-

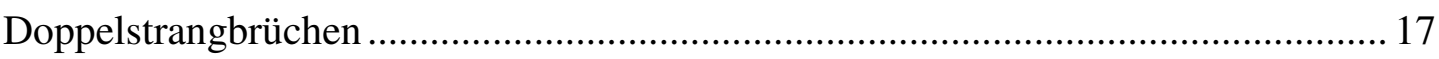

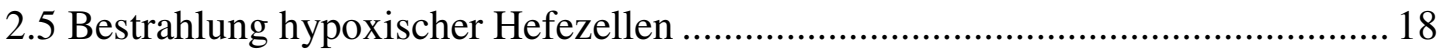

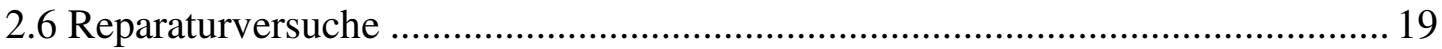

2.7 Bestimmung der DNA-Doppelstrangbrüche mittels Pulsfeldgelelektrophorese .. 19

2.7.1 Probenaufbereitung und Herstellung von Agaroseblöckchen ...................... 19

2.7.2 Herstellung eines Agarosegels und Einbetten der Agaroseblöckchen............ 20

2.7.3 Auftrennung von DNA-Molekülen nach ihrer Größe mittels

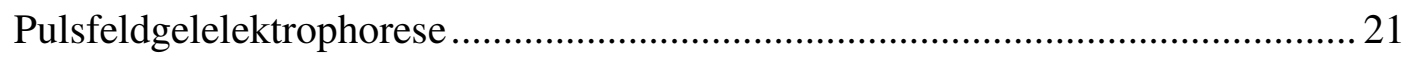

2.7.4 Darstellung der DNA mittels Ethidiumbromid.......................................... 23

2.7.5 Quantitative densitometrische Auswertungsmethoden mittels konventioneller

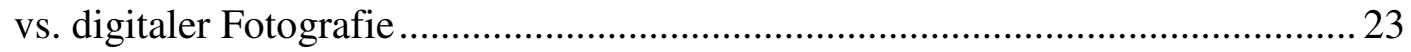

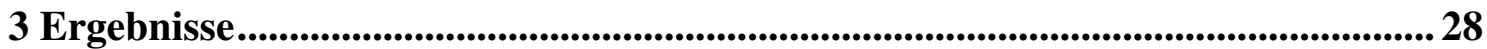

3.1 Induktion und Reparaturkinetik von Doppelstrangbrüchen nach Bestrahlung

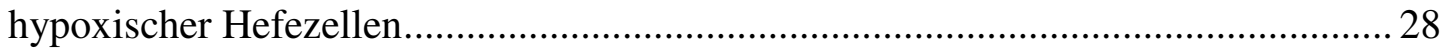


3.2 Induktion von Doppelstrangbrüchen nach Cisplatin-Behandlung von Hefezellen

3.3 Reparaturkinetik von Doppelstrangbrüchen nach kombinierter Behandlung mit Cisplatin und Bestrahlung....

3.4 Auftreten von Doppelstrangbrüchen in Cisplatin-behandelten Hefezellen während der $\mathrm{N}_{2}$-Vorbegasung

3.5 Wirkung von Cisplatin auf Induktion und Reparatur von Doppelstrangbrüchen nach Bestrahlung hypoxischer Hefezellen.

3.6 Statistischer Vergleich der Aufnahmemethoden

4 Diskussion 48

4.1 Induktion und Reparatur strahleninduzierter DNA-Doppelstrangbrüche nach alleiniger Bestrahlung 48

4.2 Induktion von Doppelstrangbrüchen durch Cisplatin-Behandlung 49

4.3 Induktion von DNA-Doppelstrangbrüchen nach $\mathrm{N}_{2}$-Begasung Cisplatinvorbehandelter Zellen

4.4 Effekt von Cisplatin auf Induktion und Reparatur strahlenbedingter DNA-

Doppelstrangbrüche

4.5 Vergleich der Auswertung mittels konventioneller Fotografie und CCD-Kamera

5 Zusammenfassung 55

6 Literaturverzeichnis 
Abkürzungsverzeichnis

A

ATPase

CCD

$\mathrm{CHEF}$

DMF

DNA

DNA-PK

DNA-PKcs

DSB

EDTA

$\mathrm{EtBr}$

G

HMG

HWZ

LMP

$\mathrm{LOH}$

NHEJ

NWM

OER

PFGE

PLD

RNA

RPA

UV

YPD
Adenin

Adenosintriphosphatase

charge-coupled-device

contour clamped homogenous electric field

dose modifying factor

deoxyribonucleic acid

DNA-abhängige Proteinkinase

catalytic subunit der DNA-abhängigen Proteinkinase

Doppelstrangbruch (-brüche)

Ethylendiamintetraacetat

Ethidiumbromid

Guanin

high mobility group

Halbwertszeit

low melting point

loss of heterozygocity

non-homologous end-joining

Nichtwuchsmedium

oxygen enhancement ratio

Pulsfeldgelelektrophorese

potentially lethal damage

ribonucleic acid

Replikations-Protein A

Ultraviolett

yeast peptone dextrose 


\section{Einleitung}

\subsection{Onkologische Epidemiologie und Therapie}

Krebserkrankungen machen in den Industrienationen die zweithäufigste Todesursache nach den Herz-Kreislauferkrankungen aus. Statistiken sagen voraus, dass ungefähr $30 \%$ aller US-Amerikaner während ihrer Lebenszeit einen malignen Tumor entwickeln werden, zwei von drei Betroffenen werden an dieser Erkrankung versterben (Andreoli et al. 1997). Die am häufigsten befallenen Organe sind bei der Frau Brustdrüse, Darm und Kolorektum, beim Mann Prostata, Kolorektum und Lunge (Krebs in Deutschland, 2006). Hierbei hat die Inzidenz bei den meisten malignen Tumoren in den letzten Jahrzehnten stetig zugenommen. Dies liegt nicht nur an der generell längeren Lebenserwartung, sondern auch an Zivilisationsfaktoren, wie z. B. Ernährung (erhöhte Fett- und verminderte Ballaststoffzufuhr, Nikotin- und Alkoholabusus) und erhöhter UV-Strahlungsexposition (Riede und Schäfer 1993).

Grundsätzlich kann jede teilungsfähige Zelle entarten. Dies kann experimentell durch chemische (z. B. Nitrosamine) und physikalische (ionisierende Strahlung, UVStrahlung) Noxen sowie durch bestimmte Viren (z. B. Papillomaviren) ausgelöst werden. Allen diesen Faktoren ist eine Wechselwirkung mit der DNA gemeinsam. Über verschiedene Mechanismen (z.B. Protoonkogen-Aktivierung, Mutation von Tumorsuppressorgenen, Verlust von Chromosomenstücken (LOH)) resultiert ein Defizit der normalen Zellregulation, das $\mathrm{zu}$ einer Zellkommunikationsstörung, Proliferationsenthemmung und Entdifferenzierung der Zelle führt. Dies sind die Ursachen für das ungehemmte Wachstum maligne entarteter Zellen (Riede und Schäfer 1993).

Die onkologische Therapie ist je nach Tumorzellbiologie und Tumorstadium unterschiedlich und individuell abzuwägen. Generell gibt es drei große Therapiepfeiler:

1. Die chirurgische Resektion, die bei den meisten soliden Tumoren zum Einsatz kommt, kann bei ausreichender Radikalität zur Kuration führen, hinterläßt jedoch häufig Mikrometastasen, so dass oft eine Radio-/ Chemotherapie nachgeschaltet bzw. gelegentlich vorgeschaltet wird.

2. Die Radiotherapie wird meist in Kombination mit der lokalen Resektion und/ oder Chemotherapie angewendet, kann aber auch bei bestimmten malignen Erkrankungen (z. B. Hodgkin-Lymphom) als Monotherapie mit kurativem Ansatz eingesetzt werden. 
3. Die Chemotherapie, bis auf Ausnahmen systemisch angewandt, kann bei einigen Malignomen als Monotherapie kurativ wirken (z. B. beim Chorionkarzinom), wird aber auch häufig neoadjuvant (d. h. präoperativ, um die Operabilität zu verbessern) und adjuvant (d.h. nach Durchführung einer lokalen Tumortherapie) durchgeführt mit der Zielsetzung einer Verminderung der systemischen Mikrometastasierung (Andreoli et al. 1997). Selbst nach Ausschöpfung aller Therapiemöglichkeiten (zu denen unter anderem auch die Hormon- und Immuntherapie zählen) kann sehr häufig keine Kuration erzielt werden. Hier wirken o. g. Maßnahmen nur palliativ und sollten in Hinsicht auf eine eventuelle Lebensverlängerung, jedoch vor allem für den Erhalt einer ausreichenden Lebensqualität angewandt werden.

Die grundsätzlichen Ziele einer kombinierten Radio- und Chemotherapie sind eine erhöhte lokale Tumorkontrolle, eine verminderte Metastasierungsrate und eine vergrößerte Überlebenswahrscheinlichkeit. Das Grundprinzip ist hierbei, einen hohen therapeutischen Quotienten zu erreichen, d.h. maximale Schädigung der malignen Zellen bei minimaler Schädigung des gesunden Gewebes. Eine verstärkte Wirkung auf den Tumor ist besonders zu erwarten, wenn Radio- und Chemotherapie allein bereits kurativ wirksam sind (Fu 1992).

\subsection{Effekte von Cisplatin}

Die zytostatische Aktivität von anorganischen Platin-Verbindungen wurde erstmalig 1969 von Rosenberg et al. beschrieben. Hauptrepräsentant dieser Verbindungsklasse ist das Cisplatin $\left(\left(\mathrm{NH}_{3}\right)_{2} \mathrm{PtCl}_{2}=\right.$ cis-Diammindichloroplatin(II) $=\operatorname{cDDP}(\mathrm{Abb}$. 1) $)$ mit einem zentralen Platinatom, welches tumorhemmende Wirkungen besitzt. Es wird heute eingesetzt in der Therapie der HNO-, Lungen-, Prostata-, Zervikal-, Ovarial-, Blasenund Speiseröhren-Karzinome sowie des malignen Melanoms, wobei die größte Wirksamkeit gegenüber den Urogenitaltumoren erzielt wird. Einhorn beschrieb 1993 komplette Remissionsraten bei Hodentumoren von bis $\mathrm{zu} 70 \%$ mit der Kombinationstherapie aus Cisplatin, Vinblastin und Bleomycin im Vergleich zu Remissionsraten von $36 \%$ bei Chemotherapien ohne Cisplatin, die in den 70er Jahren durchgeführt wurden (Hartenstein und Clemm 1995). Eine aktuelle Übersicht der klinischen Anwendung von Cisplatin und seiner Kombination mit anderen Chemotherapeutika geben Boulikas und Vougiouka (2004). Nebenwirkungen der 
Therapie mit Cisplatin sind die häufige Nephrotoxizität, gastrointestinale Irritationen, Innenohrschäden und periphere Neuropathien.

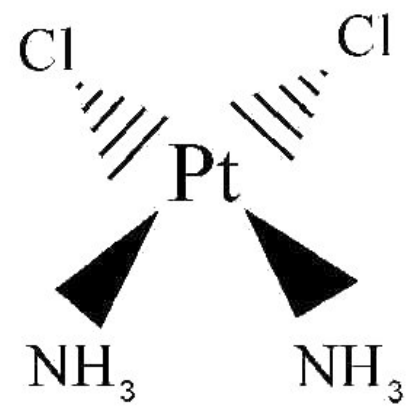

Abbildung 1: cis-Diammindichloroplatin(II)

Der Wirkmechanismus beruht auf der hohen Affintät der cis- $\left(\mathrm{NH}_{3}\right) \mathrm{Pt}^{2+}$-Einheit gegenüber den Guanin-Basen der DNA, die nach kovalenter Bindung zu CisplatinDNA-Monoaddukten und -Biaddukten innerhalb eines Stranges der DNA (Intrastrand Crosslinking) bzw. von zwei gegenüberliegenden Strängen (Interstrand Crosslinking) führt. Als Folge treten lokale Denaturierung und Destabilisierung der DNA, Störungen der Basenpaarung und Punktmutationen auf. Die Platinum-Addukte können durch Reparaturenzyme in unterschiedlichem Ausmaß entfernt werden, abhängig von der Enzymausstattung der Zelle. Ein weiterer Effekt ist die Vernetzung zwischen Cisplatin mit RNA und Proteinen, die zu einer Hemmung bestimmter Enzyme führen kann (Köpf-Maier und Köpf 1986). 


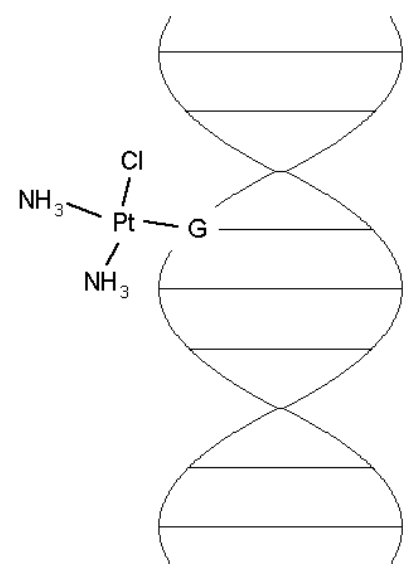

1

a

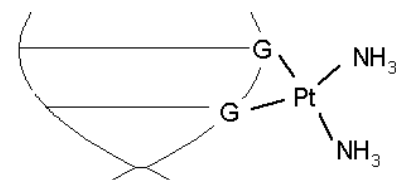

$\mathrm{b}$

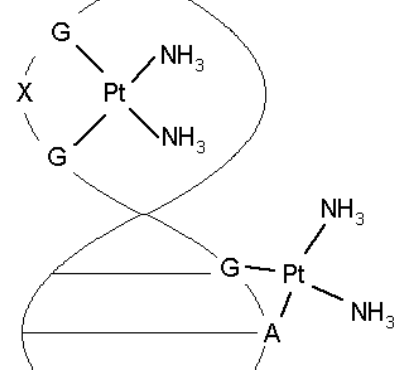

3

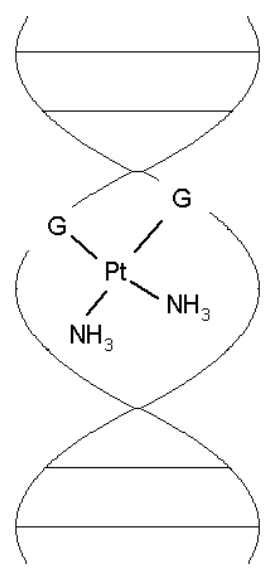

2

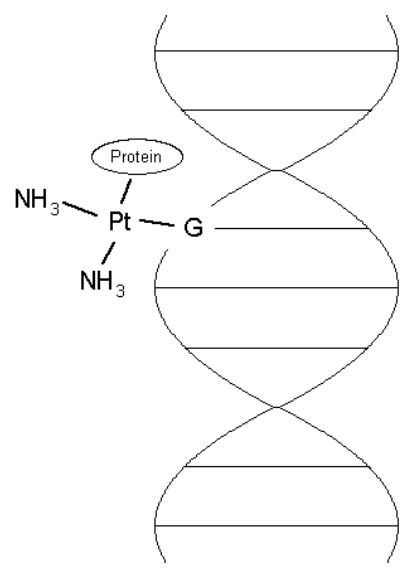

4

Abbildung 2: Mögliche DNA-Addukte nach Einwirkung von Cisplatin auf DNA (Bearbeitung der Vorlage nach Dewit 1987, S. 405).

1 Monofunktionell gebundene Cisplatin-Einheit

2 Interstrand Crosslink

3 Intrastrand Crosslink

$$
\begin{aligned}
& \text { a } 1,2 \mathrm{~d}(\mathrm{GpG}) \\
& \text { b } 1,3 \mathrm{~d}(\mathrm{GpXpG}) \\
& \text { c } 1,2 \mathrm{~d}(\mathrm{ApG})
\end{aligned}
$$

4 DNA-Protein Crosslink

Eastman beschrieb 1985 die Verteilung der Platination an der DNA. Der Intrastrand Crosslink macht den Hauptanteil aus, mit präferentieller Platination bestimmter DNASequenzen: $\mathrm{GpG}$ 65\%, $\mathrm{ApG}$ 25\%, GpXpG 6\% aller Platinationen. Interstrand Crosslinks und DNA-Protein Crosslinks sind nur in weniger als $1 \%$ aller Platinationen 
beteiligt. Auch Fichtinger-Schepman et al. berichteten 1985 eine eindeutige Präferenz von Platinverbindungen, mit Guaninen der Sequenz GpG zu reagieren.

Diese Platinationen werden mit unterschiedlicher Halbwertszeit (HWZ) von der DNA entfernt. Fraval und Roberts (1979) beschrieben für Säugerzellen unter Wuchsbedingungen eine HWZ von 28 h, bei Kulturen in stationärer Phase eine HWZ von 4 Tagen. Im letzteren Fall war eine Zunahme der Überlebenswahrscheinlichkeit der Zellen von $0,19 \%$ direkt nach der Cisplatinbehandlung auf 15,9\% nach dreitägiger Inkubationszeit nach Cisplatineinwirkung $\mathrm{zu}$ beobachten. Es konnte eine lineare Beziehung zwischen der Anzahl an Platinum-DNA-Läsionen und der Überlebenswahrscheinlichkeit der Zellen aufgezeigt werden. Es wurde auf einen enzymatischen Mechanismus der Entfernung von Platinum-DNA-Läsionen geschlossen, da in isolierter DNA keine Entfernung von Platin von der DNA beobachtet wurde. Ähnliche Ergebnisse brachten die Untersuchungen von Pera et al. (1981), die eine Zunahme der Überlebenswahrscheinlichkeit von $1 \%$ direkt nach der CisplatinBehandlung auf 30\% nach einer 6-7tägigen Inkubationszeit stationärer Zellen zeigten. Die HWZ aller Platin-Residuen betrug in dieser Studie 2,5 Tage, Interstrand Crosslinks und DNA-Protein Crosslinks hatten eine geringere HWZ von 1,5 Tagen. Jones et al. (1991) konnten in ihrer Arbeit diese schnellere Reparatur von Interstrand Crosslinks vs. der langsameren Reparatur von Intrastrand-Addukten bestätigen.

Die einzelnen DNA-Addukte tragen zur Letalität der Zellen in unterschiedlichem Ausmaß bei und in der Literatur wird kontrovers diskutiert, welches DNA-Addukt als toxischste Läsion anzusehen ist. Monoaddukte inhibieren die DNA-Synthese nicht und besitzen somit wahrscheinlich auch keine größere Toxizität (Pinto und Lippard 1985). Unter den Diaddukten werden die Interstrand Crosslinks als die toxischsten Läsionen angesehen, da sie die DNA- Replikation und Transkription hemmen (Verly and Brakier 1969, Cole 1971). Fichtinger-Schepman et al. beschrieben 1995 das Platinum-A-GDiaddukt als toxischste Läsion und gaben den Anteil der Interstrand Crosslinks an den gesamten DNA-Addukten mit 2\% an. Bei Transplatin, der im Vergleich zu Cisplatin weitaus weniger toxischen Platinverbindung, findet sich keine niedrigere Anzahl an Interstrand Crosslinks bei äquimolaren Konzentrationen bei Hefezellen und somit keine eindeutige Korrelation von DNA-Interstrand Crosslinks mit der Überlebenswahrscheinlichkeit der Zellen, zumal der Interstrand Crosslink auch nur einen geringen Anteil an der Gesamtzahl der Addukte ausmacht (Wilborn und Brendel 1989). Unter den Intrastrand Crosslinks ist nach Cisplatin-Einwirkung der GpG 
Crosslink die häufigste Form. Aus stereochemischen Gründen kann Transplatin diesen Crosslink nicht bilden (Lippert 1996). Die Addukte, die durch Transplatin entstehen, verändern die DNA-Doppelhelix in größerem Ausmaß als die durch Cisplatin induzierten Addukte (Hauptaddukt GpG) und werden somit von den Reparaturenzymen in stärkerem Maße erkannt und effizienter von der DNA entfernt, was zu der geringeren Toxizität von Trans- im Vergleich zu Cisplatin beitragen könnte (Sherman et al. 1985). Auch Lippert (1996) führte die stärkere Strukturveränderung der DNA und die größere Variabilität der gebildeten Addukte durch Transplatin als mögliche Ursache für die höhere Toxizität von Cisplatin an, weiterhin dazu beitragen könnte lt. Lippert (1996) die Tatsache, dass monofunktionelle Transplatin-DNA-Addukte im Gegensatz zu CisplatinDNA-Addukten auch durch chemische (= nicht enzymatische) Reparatur von der DNA entfernt werden können. Leng et al. (2000) zeigten, dass durch Transplatin hauptsächlich monofunktionelle Addukte an Guanin-Basen gebildet werden, die die DNA-Struktur weniger verändern und leichter repariert werden können als bifunktionelle Addukte sowie Interstrand Crosslinks an Guanin- und Cytosin-Basen. Kasparkova et al. (2001) fanden, dass Cisplatin-Addukte, insbesondere der 1,2 GpG Intrastand Crosslink, die Bindungsfähigkeit des Tumorsupressors p53 an DNA, die wichtig für die tumorunterdrückende Funktion von p53 ist, vermindert. TransplatinAddukte beeinflussen die Bindungsfähigkeit von p53 an DNA dagegen nicht. Auch hier zeigt sich der nur durch Cisplatin, nicht dagegen durch Transplatin gebildete 1,2 GpG Intrastrand Crosslink über die verminderte DNA-Bindungsfähigkeit von p53 als die für die biologische Wirksamkeit entscheidendere Läsion.

Chu (1994) beschrieb, dass bei Säugerzellen die bei einer letalen Dosis gebildeten DNA-Addukte zum Arrest im $\mathrm{G}_{2}$-Stadium des Zellzyklus führen, die Apoptose induzieren und somit den Zelltod verursachen. Bei subletalen Dosen können die Zellen durch verschiedene Mechanismen, unter anderem Veränderung von zellulärer Aufnahme und Abgabe von Cisplatin, veränderten Glutathion- und Metallothioninspiegeln und vor allem durch Aktivierung von Reparaturproteinen, dem Zelltod entgehen und eine Resistenz entwickeln.

Es gibt eine Reihe von Untersuchungen über die Interaktion zwischen Proteinen und Cisplatin-DNA-Addukten. Eine wichtige Rolle hierbei scheint die DNA-abhängige Proteinkinase (DNA-PK), eine Serin-Threonin-Proteinkinase, zu spielen. Sie besteht aus zwei Komponenten: dem DNA-Bindungsprotein $\mathrm{Ku}$, einem Heterodimer von 70 und 86 $\mathrm{kDa}$ und der katalytischen Untereinheit $\mathrm{DNA}-\mathrm{PK}_{\mathrm{CS}}$ mit einer Größe von 465 kDa. 
DNA-PK wird benötigt, um z. B. durch ionisierende Strahlung induzierte DSB mittels NHEJ (nicht-homologe Verknüpfung von DNA-Enden) zu reparieren. Der genaue Wirkungsmechanismus ist noch unklar, ein Modell für die Aktivierung wurde jedoch basierend auf der Struktur des Moleküls (Leuther et al. 1999) von deFazio et al. (2002) beschrieben: $\mathrm{Ku}$ heftet sich an DNA-Enden und rekrutiert damit DNA-PK $\mathrm{CS}_{\text {, welches }}$ sowohl DNA-Doppel- als auch Einzelstrangenden bindet. Zwei DNA-PK ${ }_{\mathrm{CS}}-M_{\text {Moleküle }}$ bilden dann einen synaptischen Komplex, welcher die DNA-PK aktiviert. Nach Phosphorylierung verschiedener Proteine, die schließlich zu einer Aktivierung von Xrcc4 (DNA-Reparatur Protein) und Ligase IV führen, werden die DNA-Enden miteinander verbunden. Turchi und Henkels (1996) und Turchi et al. (1997 und 2000) untersuchten den Wirkungsmechanismus von DNA-PK bei Cisplatin-geschädigter DNA und fanden eine Hemmung der DNA-PK-Aktivität nach Cisplatinbehandlung. Ku kann Cisplatin-geschädigte DNA zwar binden, zeigt aber mit zunehmender Cisplatin-AdduktFormation eine verminderte Fähigkeit, auf der DNA zu translozieren. Daraus resultiert schließlich eine reduzierte Aktivität der $\mathrm{DNA}-\mathrm{PK}_{\mathrm{CS}}$ und damit eine Hemmung der NHEJ-Reparatur. DNA-PK phosphoryliert u. a. RPA, welches in der eukaryoten Zelle u. a. bei der DNA-Replikation, Reparatur und Rekombination eine Rolle spielt (Wold 1997). RPA bindet bevorzugt an Cisplatin-geschädigte DNA und ist wichtig für die Nukleotidexzisionsreparatur (Patrick und Turchi 1998).

Cisplatin-DNA-Addukte werden durch eine Kombination von Nukleotidexzisions- und Rekombinationsreparatur von der DNA entfernt (Sancar und Sancar 1988). Vereinfacht dargestellt beinhaltet die Nukleotidexzisionsreparatur die Erkennung des Schadens, Inzision des DNA-Stranges auf beiden Seiten der Läsion, Entfernung des veränderten Oligonukleotids, Auffüllen der entstandenen Lücke mit Hilfe von DNA-Polymerasen und Verbindung der DNA-Stücke durch DNA-Ligase. Es sind Proteine bekannt, die spezifisch an Cisplatin-, nicht aber an Transplatin-geschädigte DNA binden und zur Gruppe der high-mobility-group(HMG)-Proteine der Klasse 1 und 2 gehören (Hughes et al. 1992). Durch die Bindung der HMG-Proteine an Cisplatin-geschädigte DNA kann die Reparatur dieser DNA-Schäden inhibiert werden (Turchi et al. 1996, Cohen und Lippard 2001). Ixr1 (intrastrand crosslink recognition) ist ein Hefeprotein, das zur Gruppe der HMG-Proteine gehört und spezifisch an Cisplatin-geschädigte DNA bindet, jedoch nicht an durch Transplatin-veränderte DNA (Brown et al. 1993). Ixr1 maskiert Cisplatin-DNA-Addukte und verhindert so deren Exzisionsreparatur, was zu einer erhöhten Sensitivität der Zelle gegenüber Cisplatin führt. Eine ixr1-defiziente 
Hefemutante weist somit eine höhere Resistenz gegenüber Cisplatin auf (McA'Nulty et al. 1996, McA'Nulty und Lippard 1996).

Wie Frankenberg-Schwager et al. (2005) an der bei der restriktiven Temperatur von $36^{\circ} \mathrm{C}$ rekombinationsdefizienten Hefemutante rad54-3 gezeigt haben, können nach Cisplatineinwirkung DSB entstehen. In Hefezellen werden DSB hauptsächlich durch den Mechanismus der homologen Rekombination repariert (Osman und Subramani 1998), im Gegensatz dazu herrschen bei Säugerzellen illegitime Rekombinationsmechanismen wie z. B. das NHEJ vor (Haber 1999). Bei der homologen Rekombination werden DNA-Strangbrüche durch Kopieren der verlorengegangenen DNA von einem Schwesterchromatid oder dem homologen Chromosom repariert. Die homologe Rekombination ist, im Gegensatz z. B. zum NHEJ, ein konservativer, aber aufwändiger Reparaturmechanismus mit einer geringen Fehlerrate (Haber 1999). Es existieren verschiedene Modelle zur Reparatur von DSB durch homologe Rekombination, in Abbildung 3 wird ein Modell (nach Pâques und Haber 1999) schematisch dargestellt. Hierbei werden zunächst die 5'-Enden der DNA reseziert, dann invadieren die 3'-Überhänge die intakte homologe Vorlage. Ausgehend von den 3'-Überhängen erfolgt die Reparatursynthese unter Bildung von Holliday Junctions, die aus vier gekreuzten DNA-Strängen bestehen. Die Holliday Junctions können auf zwei verschiedene Arten aufgelöst werden: ohne Crossing over werden beide Holliday Junctions auf gleiche Weise aufgelöst, dadurch werden die DNAStränge der homologen Chromosomen nicht ausgetauscht, beim Crossing over dagegen erfolgt ein Austausch der homologen Chromosomen. 

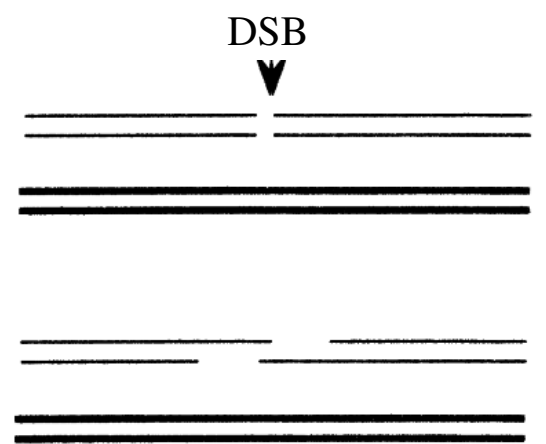

Prozessierung der Bruchstelle, Erzeugung von 3'Überhängen

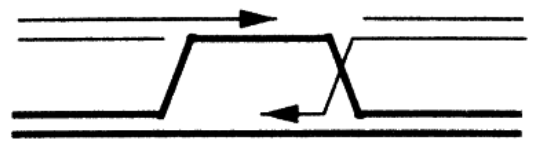

Stranginvasion des 3'-Überhanges

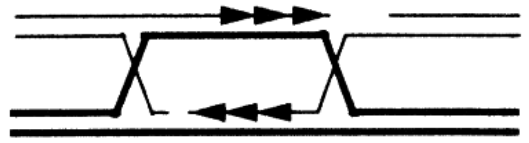

Reparatursynthese ausgehend von den 3'-Überhängen

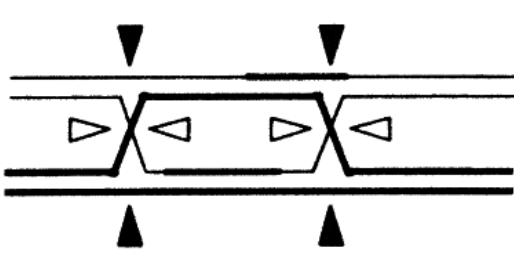

Auflösung der Holliday Junctions

Heteroduplex ohne

Heteroduplex mit

Crossing over

Crossing over

Abbildung 3: Das DSB-Modell der homologen Rekombination (Bearbeitung der Vorlage nach Pâques und Haber 1999, S. 360).

Die Zytotoxizität von Cisplatin unter hypoxischen vs. oxischen Bedinungen wird in der Literatur kontrovers diskutiert. Während z. B. Teicher et al. (1990) eine verminderte Toxizität von Cisplatin unter hypoxischen Bedingungen beschreibt, zeigen Stratford et al. (1980) und Matthews et al. (1993) eine höhere Toxizität von Cisplatin unter Hypoxie. Dies könnte durch die unterschiedlichen Versuchsanordnungen der einzelnen Versuchsgruppen bedingt sein. Nach Studium der Literatur scheint der unter 1.4 
beschriebene radiosensibilisierende Effekt von Cisplatin insbesondere unter Hypoxie zu bestehen (Skov 1992), so dass in der vorliegenden Arbeit die Cisplatinbehandlung unter oxischen, die Bestrahlung der Hefezellen jedoch unter hypoxischen Bedingungen erfolgte.

\subsection{Effekte ionisierender Strahlung}

Bei der Einwirkung von ionisierender Strahlung auf Zellen oder Gewebe entstehen Radikale durch die Radiolyse des Wassers (Wasserstoffradikale und die stark oxidierend wirkenden Hydroxylradikale). Bei Anwesenheit von Sauerstoff enstehen zusätzlich Superoxid- und Perhydroxylradikale, die die erhöhte biologische Wirksamkeit in sauerstoffversorgtem Gewebe erklären. Die o. g. Radikale, die auch unter normalen Bedingungen in geringeren Mengen in der Zelle entstehen, können bei hohen Konzentrationen nicht ausreichend inaktiviert werden und führen so zu Schäden in der DNA, indem sie chemisch mit ihr reagieren. Diese Schäden (Einzelstrangbrüche, Doppelstrangbrüche (DSB), chemische Änderung oder Abspaltung der Purin- und Pyrimidinbasen) können zu Störungen der Replikation und Transkription, zu Genmutationen und Chromosomenaberrationen führen. Die Schäden an der DNA können enzymgesteuert repariert werden. Abhängig von der Dosis und Art der Bestrahlung, An- und Abwesenheit von Sauerstoff, Ploidiegrad und Position der Zelle im Zellzyklus ändert sich die Wahrscheinlichkeit, mit der die Zelle zugrunde geht bzw. mit der sie mit nicht letalen Veränderungen oder unbeeinflußt weiterlebt (Lissner und Fink 1992).

Phasen erhöhter Strahlenempfindlichkeit sind der Übergang von der $\mathrm{G}_{1}$ - zur S-Phase sowie die Mitose. Zellen, die sich in der postmitotischen Ruhephase $\mathrm{G}_{0}$ befinden, sind relativ strahlenresistent. In der vorliegenden Arbeit werden Zellen der Hefe Saccharomyces cerevisisae verwendet, die sich in der stationären Zellzyklusphase befinden. Diese ist dadurch gekennzeichnet, dass die Zellen bei limitiertem Nährstoffangebot ihr Wachstum einstellen, in die $\mathrm{G}_{0}$-Phase eintreten und damit synchronisiert werden (Werner-Washburne et al. 1996).

Zellen sind umso strahlenempfindlicher, je mehr DNA sie enthalten. Eine Säugetierzelle enthält ca. 300mal mehr DNA als eine Hefezelle. Um den gleichen Effekt auf die Zellinaktivierung zu erzielen, müssen Hefezellen im Vergleich zu Säugetierzellen mit der 300fachen Dosis bestrahlt werden. 
Der durch ionisierende Strahlung induzierte DNA-DSB stellt eine kritische Zellläsion dar. Für Hefezellen besteht eine lineare Beziehung zwischen der Anzahl an induzierten DSB und der applizierten Strahlendosis, wie z. B. Frankenberg-Schwager et al. 1979 gezeigt haben. Nach 48 Stunden Inkubationszeit in Nichtwuchsmedium (NWM) bleiben DSB nach optimaler Reparatur zurück, die unter diesen Bedingungen auch nach weiterer Inkubationszeit irreparabel sind. Die Anzahl der nicht reparierten DSB steht hierbei in einer quadratischen Funktion zur applizierten Dosis (Frankenberg-Schwager et al. $1980 \mathrm{~b})$.

Ein DSB ist eine potentiell tödliche Läsion (PLD) (Ho 1975). Resnick und Martin beschrieben 1976, dass bei DSB-reparaturdefekten Mutanten der Hefezelle Saccharomyces cerevisiae ein bis zwei DSB pro Zelle mit einem tödlichen Ereignis korrelieren. Frankenberg et al. (1981) zeigten, dass etwa ein DSB pro Zelle zu deren Untergang führt. Dabei sind zwei Mechanismen für den Zelltod verantwortlich: Wird ein DSB nicht repariert (wie z. B. bei DSB-reparaturdefekten Zellen) wirkt er an sich bereits tödlich, zum anderen können in reparaturkompetenten Zellen zwei DSB miteinander interagieren und über eine binäre Missreparatur zum Zelltod führen (Frankenberg-Schwager et al. 1980 a und b, Frankenberg-Schwager et al. 1985; Frankenberg-Schwager und Frankenberg 1990).

Unter Einfluss von Sauerstoff besteht eine erhöhte Wirksamkeit der Bestrahlung durch die zusätzlich entstehenden Superoxid- und Perhydroxylradikale, dies ist der so genannte Sauerstoffeffekt oder OER, der unter verschiedenen Bedingungen variieren kann. Frankenberg-Schwager et al. haben 1979 beschrieben, dass der OER für die Induktion von DSB in Hefezellen bei $3.0 \pm 0.1$ liegt, für die Koloniebildungsfähigkeit dagegen bei $1.9 \pm 0.2$. Darüber hinaus zeigten Frankenberg-Schwager et al. 1991, dass der OER für DSB im Verlauf der DSB-Reparatur abnimmt. Die DSB, die in oxischen Zellen induziert wurden, zeigten eine biphasische Kinetik der Reparatur. Eine komplexere Reparaturkinetik der DSB zeigte sich nach Bestrahlung anoxischer Zellen. Hier traten sekundäre DSB auf, die wahrscheinlich während der Inkubation bestrahlter Zellen durch reparaturbedingte Einschnitte anderer strahleninduzierter DNA-Schäden entstanden waren. Dies ist eventuell der Grund für den höheren Anteil an nicht reparierbaren DSB, der in unter Anoxie bestrahlten Zellen gemessen wurde.

Die Induktion und Reparatur der DSB ist nicht nur abhängig vom Oxygenierungsstatus der Zellen zum Zeitpunkt der Bestrahlung, sondern auch von den Konditionen der Inkubation der Zellen nach Bestrahlung. Mehrfach wurde in Untersuchungen an 
Hefezellen die Inkubation in Nichtwuchsmedium (z. B. Phosphatpuffer) der Inkubation in Wuchsmedium (z. B. YPD) gegenübergestellt (Frankenberg-Schwager et al $1980 \mathrm{a}$ und b; Frankenberg-Schwager et al. 1988 a; Frankenberg-Schwager et al. 1995). Dabei zeigte sich, dass die Reparatur von DSB unter Wuchsbedingungen zwar schneller abläuft, jedoch eine geringere Genauigkeit als die DSB-Reparatur unter Nichtwuchsbedingungen aufweist. Dies wurde auch mit Hilfe eines Plasmidsystems untersucht, in welches DSB oder Deletionen definierter Größe durch Restriktionsenzyme eingeführt wurden. Nach Transfektion des Plasmids in Hefezellen wurde festgestellt, dass unter Wuchsbedingungen die Verknüpfung der DNA-Enden in nur 35\% aller Fälle korrekt war, während unter Nichtwuchsbedingungen der Anteil der korrekten Verknüpfungen bei 52\% lag (Frankenberg-Schwager et al. 1995). In Übereinstimmung damit ist das Überleben der Zellen höher, wenn diese nicht sofort nach Bestrahlung auf Wuchsagar plattiert werden, sondern erst nach einer dazwischen geschalteten Inkubation unter Nichtwuchsbedingungen.

\subsection{Kombination von Cisplatin und Bestrahlung}

Ein wichtiges Ziel in der Strahlentherapie von malignen Neoplasien ist die Erhöhung der Strahlenempfindlichkeit von Tumorzellen. Stoffe, die in den DNA-Stoffwechsel eingreifen, wie z. B. Doxorubicin, Adriamycin und Daunorubicin, erhöhen die zelluläre Strahlenempfindlichkeit. Carde und Laval (1981) stellten bei Hepatomzellen auch bei der Kombination von Cisplatin und Bestrahlung eine erhöhte Zellinaktivierung fest. Dieser Effekt ist höher bei Hypoxie vs. Oxie und bei niedrigen vs. hohen Bestrahlungsdosen, wie Korbelik und Skov (1989) bei V79-Hamsterzellen zeigen konnten. Melvik und Pettersen (1988) beschrieben einen bei höheren Temperaturen $\left(37^{\circ} \mathrm{C}\right.$ vs. $\left.22^{\circ} \mathrm{C}\right)$ stärker ausgeprägten radiosensibilisierenden Effekt von Cisplatin bei Bestrahlung von hypoxischen Cervixcarcinomzellen. Hier zeigten sich jedoch hypoxische Zellen bei der Cisplatinbehandlung weniger empfindlich als oxische Zellen. Die Cisplatinbehandlung wurde in der vorliegenden Arbeit an oxischen Zellen vorgenommen (s. Kapitel 1.2). Die Bestrahlung cisplatinvorbehandelter Zellen wurde in den vorliegenden Experimenten unter Hypoxie $\left(\mathrm{N}_{2}\right.$-Begasung) durchgeführt, da, wie oben angeführt, so eine verstärkte Wirkung der kombinierten Behandlung mit Cisplatin und Bestrahlung zu erwarten war (Carde und Laval 1981, Korbelik und Skov 1989). Der radiosensibilisierende Effekt wird durch eine Inhibition der Reparatur der Strahlenschäden durch Cisplatin erklärt, z. B. wurde von Dolling et al. (1998) bei 
Säugerzellen gezeigt, dass die Reparatur von strahleninduzierten DNA-Brüchen durch DNA-Cisplatin-Addukte beeinträchtigt wird. Cisplatin sollte dabei einige Stunden vor der Bestrahlung verabreicht werden (Coughlin und Richmond 1989; Begg 1990), da die DNA-Cisplatin-Addukte erst in diesem Zeitraum ein Maximum erreichen und dann konstant bleiben.

Die vorliegende Arbeit untersucht die mutmaßliche Rolle von DSB am radiosensibilisierenden Effekt von Cisplatin im Modell der Hefemutante rad54-3, die einen temperaturabhängigen Defekt in der Reparatur von DSB aufweist.

\subsection{Mutante rad54-3 der Hefe Saccharomyces cerevisiae als Modell}

Die Hefe Sacchoromyces cerevisiae ist ein eukaryoter Einzeller, dessen Genom gut untersucht und charakterisiert ist (Mortimer et al. 1992). Game und Cox haben 1971 Mutanten der Hefe Saccharomyces cerevisiae beschrieben, die verschiedene Reparaturdefekte besitzen. Es ist daher ein geeignetes Modell, um sowohl biologische als auch molekulare Aspekte von DNA-Schäden und deren Reparatur zu untersuchen.

Die in der vorliegenden Arbeit verwendeten diploiden Zellen der Mutante rad54-3 zeigen eine Temperaturabhängigkeit der DSB-Reparatur. Bei der restriktiven Temperatur von $36^{\circ} \mathrm{C}$ ist keine DSB-Reparatur nachweisbar, und die Zellen sind sehr empfindlich gegenüber ionisierenden Strahlen. Bei der permissiven Temperatur von $23^{\circ} \mathrm{C}$ findet DSB-Reparatur statt, was zu einer erhöhten Strahlenresistenz führt (Budd und Mortimer 1982). DSB werden in Hefezellen hauptsächlich durch den Mechanismus der homologen Rekombination (s. Kapitel 1.2) repariert. Die mitotische Rekombination und somit die Rate an Genkonversionen bei dieser Mutante ist bei der restriktiven Temperatur vermindert (Saeki et al. 1980, Frankenberg-Schwager et al. 1994 a). Mit einem einfachen Temperaturshift läßt sich bei der Hefemutante rad54-3 die homologe Rekombination, somit auch die DSB-Reparatur an- und abschalten, was ein Vorteil in der isolierten Betrachtung des Reparaturmechanismus der homologen Rekombination, der Induktion von DSB und deren nachfolgender Reparatur ist. Die Nukleotidsequenz des RAD54-Gens, welche ca. 3,0 kb beträgt, wurde von Emery et al. (1991) beschrieben.

Das Gen kodiert das Protein Rad54p, welches eine DNA-abhängige ATPase-Aktivität besitzt und wahrscheinlich zur Gruppe der Chromatinstruktur-verändernden Proteine gehört. Sein Beitrag zur Rekombinationsreparatur könnte somit in einer Ummodellierung der Chromatinstruktur liegen, wodurch Reparaturproteinen der 
Zugang zu den DNA-Schäden gewährt wird (Pâques und Haber 1999). Das RAD54-Gen ist nicht essentiell für das Überleben der Hefezelle, aber von großer Bedeutung für die DSB-Reparatur. Cole et al. (1987) fanden, dass die Expression des RAD54-Gens durch verschiedene DSB verursachende Substanzen induziert werden kann.

Der Mechanismus der DSB-Reparatur ist unterschiedlich in Säuger- und Hefezellen. Während in Säugerzellen das DSB end-joining, eine Form der nichthomologen (illegitimen) Rekombination dominiert, herrscht bei Hefezellen die homologe Rekombination zwischen Chromosomen oder Schwesterchromatiden vor (Osman und Subramani 1998). Bei dieser Interaktion müssen Hunderte von Basenpaaren (fast) perfekt zueinander passen (Pâques und Haber 1999).

DSB-reparaturdefiziente Mutanten von Hefezellen, z. B. die Mutante rad52, sind hypersensitiv gegenüber Cisplatin (Hannan et al. 1984, Abe et al. 1994). Dolling et al. (1999) untersuchte die Wirkung von Cisplatin in Kombination mit Bestrahlung oxischer und hypoxischer Zellen verschiedener Mutanten von Saccharomyces cerevisiae. Es fand sich eine Radiosensibilisierung durch Cisplatin in rekombinationsfähigen Zellen. Dagegen zeigten rekombinationsdefekte Zellen der Mutante rad52 keine Radiosensibilisierung. Dies deutet darauf hin, dass der radiosensibilisierende Effekt von Cisplatin durch eine Inhibition von DNA-Reparaturprozessen bedingt ist, die die homologe Rekombination beinhalten. Dolling et al. (1999) fanden in ihrer Arbeit keinen Unterschied in der Radiosensibilisierung durch Cisplatin bei Bestrahlung der Zellen unter Hypoxie vs. Oxie. Dies steht im Gegensatz zu den Untersuchungen von Korbelik und Skov (1989), die eine verstärkte Radiosensibilisierung durch Cisplatin bei Bestrahlung hypoxischer Säugerzellen beobachteten. In der vorliegenden Arbeit erfolgte trotz der nicht eindeutigen Ergebnisse in der Literatur die Cisplatin-Behandlung unter Oxie, die Bestrahlung jedoch unter hypoxischen Bedingungen.

Erste Hinweise auf eine mögliche Rolle von DSB für die cytotoxische Wirkung von Cisplatin deuteten sich durch die erhöhte Inaktivierung von rad54-3-Zellen bei der restriktiven $\left(36^{\circ} \mathrm{C}\right)$, nicht aber bei der permissiven Temperatur $\left(23^{\circ} \mathrm{C}\right)$ für die DSBReparatur an (Frankenberg-Schwager et al. 1988 b). Der direkte Nachweis dieser DSB gelang Frankenberg-Schwager et al. (2005): Rad54-3-Zellen, die eine Stunde mit Cisplatin behandelt worden waren, akkumulierten DSB im Verlauf einer nachfolgenden Inkubation in Wuchsmedium, wenn deren Reparatur bei $36^{\circ} \mathrm{C}$ gehemmt wurde. Das Maximum an DSB war nach etwa 24 Stunden erreicht. Danach blieb das Niveau an 
DSB bei $36^{\circ} \mathrm{C}$ konstant, während bei der permissiven Temperatur $\left(23^{\circ} \mathrm{C}\right)$ eine Abnahme der DSB durch Reparatur erfolgte (Greif 1999).

\subsection{Fragestellungen}

Bisher liegen keine Untersuchungen über die Reparatur von DSB nach Bestrahlung hypoxischer Zellen der Hefemutante rad54-3 allein und in Kombination mit einer vorausgegangenen Behandlung mit Cisplatin vor. Deshalb wurde zunächst die Induktion von DSB nach Bestrahlung hypoxischer Zellen gemessen und die Reparaturkinetik dieser DSB unter Nichtwuchsbedingungen verfolgt. Daran anschließend wurde untersucht, wie sich eine Vorbehandlung der Zellen mit Cisplatin auf die Reparatur strahleninduzierter DSB auswirkt. Diese Untersuchungen sollen einen Beitrag zum Verständnis der Wechselwirkungen auf der Ebene von DSB liefern, die nach kombinierter Behandlung mit Cisplatin und Bestrahlung auftreten. Möglicherweise lassen sich aus solchen Untersuchungen Verbesserungsansätze für die Kombinationstherapie ableiten.

Die vorliegende Arbeit untersucht vor diesem Hintergrund folgende Fragen:

1. In welchem Ausmaß treten DSB nach alleiniger Bestrahlung mit verschiedenen Dosen auf und wie erfolgt die Reparaturkinetik?

2. Beeinflusst die Vorbehandlung mit Cisplatin das Ausmaß bestrahlungsinduzierter DSB und deren anschließende Reparatur?

3. Stellt die $\mathrm{N}_{2}$-Begasung vor der Bestrahlung einen methodischen Störfaktor dar und wie sollten die Ergebnisse bereinigt werden?

4. Ist die Vergleichbarkeit der Ergebnisse nach Auswertung der Aufnahmen mittels konventioneller vs. digitaler Fotografie gegeben? 


\section{Material und Methoden}

\subsection{Zellen}

Zur Durchführung der Versuche wurden diploide Zellen der temperaturabhängigen radiosensitiven Mutante rad54-3 der Hefe Saccharomyces cerevisiae verwendet (Game und Mortimer 1974), die freundlicherweise Dr. J. Game zur Verfügung gestellt hat. Diese Mutante zeigt bei der restriktiven Temperatur von $36^{\circ} \mathrm{C}$ keine Reparatur von DSB und ist strahlenempfindlich, bei der permissiven Temperatur von $23^{\circ} \mathrm{C}$ ist die DSBReparatur jedoch möglich, dies macht die Zellen strahlenresistent (Budd und Mortimer 1982). Diese Temperaturabhängigkeit bezieht sich nur auf die DSB-Reparatur durch homologe Rekombination, andere DNA-Schäden, wie z. B. Basenschäden und Einzelstrangbrüche werden sowohl bei $23^{\circ} \mathrm{C}$ als auch bei $36^{\circ} \mathrm{C}$ repariert (FrankenbergSchwager et al. 1987).

\subsection{Zellkultur und Weiterzucht}

Für die Versuche wurden bei $-20^{\circ} \mathrm{C}$ eingefrorene Zellen aufgetaut und auf jeweils $20 \mathrm{ml}$ YPD-Agar (1\% Yeast Extract, 2\% Pepton, 2\% Glukose, 0,75\% Oxoid-Agar) in einer sterilen Petrischale bei $30^{\circ} \mathrm{C}$ im Brutschrank 3-4 Tage lang bis zur Bildung von Makrokolonien bebrütet. Danach wurden die Zellen bei $4^{\circ} \mathrm{C}$ aufbewahrt. Alle 8 Tage wurde eine Kolonie mit einer Impföse für die Weiterzucht auf eine frische Stammplatte ausgestrichen und bebrütet.

Für jeden Versuch wurden jeweils 10 Kolonien von der Stammplatte mit einer sterilen Impföse abgenommen und die Zellen in einem Erlenmeyer-Kolben in $100 \mathrm{ml}$ flüssigem YPD (1\% Yeast Extract, 2\% Pepton, 2\% Glukose) suspendiert. Dieser Ansatz wurde in einem $30^{\circ} \mathrm{C}$-Brutschrank unter Schütteln inkubiert. Nach Erreichen der stationären

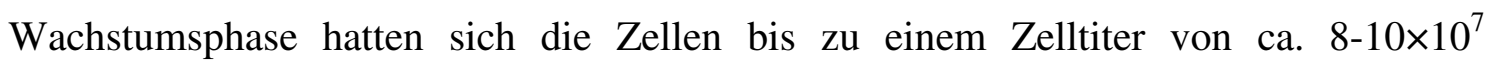
Zellen/ml vermehrt. Alle Manipulationen mit den Zellen fanden unter sterilen Bedingungen statt.

\subsection{Bestimmung des Zelltiters und Waschen der Hefezellen}

Der Zelltiter wurde mit einer Neubauer-Zählkammer bei 320facher Vergrößerung bestimmt. Um die exakte Zellzahl bestimmen zu können, mussten höhere 
Ausgangskonzentrationen vorher entsprechend mit Puffer auf den zum Zählen

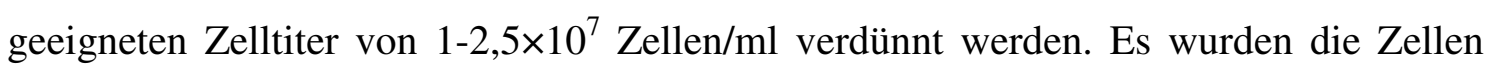
von zwei bis vier Großquadraten, jeweils bestehend aus 16 Kleinquadraten, gezählt. Mittels des bekannten Volumens von 4 nl über einem Großquadrat, unter Einrechnung der Verdünnung, konnte der Zelltiter (Zellzahl/ml) berechnet werden.

Pro Versuchsansatz wurde eine Zellsuspension mit etwa $6-7 \times 10^{9}$ Zellen mit $6000 \times \mathrm{g}$ bei $4^{\circ} \mathrm{C}$ für eine Minute zentrifugiert (Laborkühlzentrifuge Typ 4123 Minifuge 2 Fa. Haereus-Christ) und der Überstand dekantiert. Die sedimentierten Zellen wurden in 10 ml $67 \mathrm{mM}$ Phosphatpuffer (59 mM KH $\mathrm{KHO}_{4}, 8 \mathrm{mM} \mathrm{Na} \mathrm{HPO}_{4} \times 2 \mathrm{H}_{2} \mathrm{O}, \mathrm{pH}$ 7,0) suspendiert, erneut zentrifugiert und wieder resuspendiert. Nach einer zweimaligen Waschung waren die Zellen von YPD-Resten weitestgehend befreit und konnten der weiteren Behandlung, wie unter 2.5 und 2.6 beschrieben, zugeführt werden.

2.4 Behandlung der Hefezellen mit Cisplatin und Akkumulation von DNADoppelstrangbrüchen

Die gewaschenen, in $10 \mathrm{ml} 67 \mathrm{mM}$ Phosphatpuffer suspendierten Zellen wurden im Verhältnis 3:1 (Cisplatin-Ansatz:Kontrollansatz) auf zwei Plastikröhrchen verteilt und durch Zentrifugation sedimentiert. Die für den Cisplatin-Versuch bestimmten Zellen wurden in 0,75 ml Cisplatin-Lösung (Cisplatin-Lösung 100, GRY-Pharma GmbH, 0,5 $\mathrm{mg}$ Cisplatin $/ \mathrm{ml}=1,67 \mathrm{mM}$ ) resuspendiert, welche mit einer Kanüle unter sterilen Bedingungen entnommen wurde. Die Cisplatin-Behandlung der Zellen dauerte eine Stunde und wurde im $36^{\circ} \mathrm{C}$-Brutschrank unter konstanter Rollbewegung durchgeführt, um eine homogene Suspension der Zellen zu gewährleisten. Bei dieser Temperatur können eventuelle während der Cisplatin-Behandlung auftretende DSB von der Mutante rad54-3 nicht repariert werden. Die Kontrolle wurde entsprechend behandelt, wobei Cisplatin durch Aqua bidest ersetzt wurde. Danach wurden beide Ansätze zentrifugiert und die sedimentierten Zellen zweimal mit jeweils $5 \mathrm{ml}$ Phosphatpuffer gewaschen. Die sedimentierten Zellen wurden danach in $48 \mathrm{ml}$ auf $36^{\circ} \mathrm{C}$ vorgewärmtes YPD (CisplatinAnsatz) bzw. in $16 \mathrm{ml}$ YPD (Kontrollansatz) resuspendiert, so dass für beide Ansätze der gleiche Zelltiter (ca. $1,0 \times 10^{8}$ Zellen/ml) vorlag, und unter Schütteln im $36^{\circ} \mathrm{C}$ Brutschrank für 24 Stunden inkubiert. Wie in einer vorangegangenen Untersuchung gezeigt wurde, lassen sich unter diesen Bedingungen in den Zellen DSB nachweisen, die nach 24 Stunden ihren Maximalwert erreichen (Frankenberg-Schwager et al. 2005). Während der 24stündigen YPD-Inkubation der Cisplatin-behandelten Zellen erfolgte 
eine Vermehrung des Ausgangstiters von $1,0 \times 10^{8}$ Zellen/ml bis auf etwa $1,4 \times 10^{8}$ Zellen/ml.

Nach der Inkubation in YPD bei $36^{\circ} \mathrm{C}$ wurden die Zellen zweimal mit Phosphatpuffer gewaschen, um YPD-Reste zu entfernen. Zu Beginn der Versuchsreihen wurde dazu Phosphatpuffer mit Zimmertemperatur $\left(20^{\circ} \mathrm{C}\right)$ benutzt, später wurde $4^{\circ} \mathrm{C}$ kalter Puffer verwendet, um Reparaturprozesse möglichst gering zu halten. Die in Phosphatpuffer resuspendierten Zellen wurden nun einer Bestrahlung (s. 2.6) zugeführt. Für die Messung von DSB wurde nach der einstündigen Cisplatin-Behandlung sowie nach der 24stündigen Inkubation der Zellen in YPD Proben (je $4 \times 10^{8}$ Zellen) entnommen, die Aufarbeitung der Proben wird in Kapitel 2.8.1 beschrieben.

\subsection{Bestrahlung hypoxischer Hefezellen}

Gewaschene, unbehandelte oder Cisplatin-behandelte Zellen wurden in $8 \mathrm{ml}$ Phosphatpuffer (Titer $7-8 \times 10^{8}$ Zellen/ml) resuspendiert, in ein Bestrahlungsgefäß überführt und bis zur Begasung auf Eis gekühlt. Das Bestrahlungsgefäß wurde in einen Behälter eingesetzt, der mit $4^{\circ} \mathrm{C}$ kaltem Wasser durchspült wurde, um Reparaturprozesse während der Begasungs- und Bestrahlungszeit zu minimieren. Zur Gewinnung von hypoxischen Zellen wurde in die zu bestrahlende Suspension über einen Sterilfilter (Porengröße 0,2 $\mu \mathrm{m}, \mathrm{Fa}$. Sartorius) ein Gasgemisch aus 95\% $\mathrm{N}_{2}$ und $5 \% \mathrm{CO}_{2}$ mit einer Flußrate von $301 \times \mathrm{h}^{-1}$ eingeleitet, wodurch auch eine Durchmischung der Suspension erzielt wurde. In Vorversuchen wurde festgestellt, dass 20 Minuten Begasung der Zellsuspension ausreichten, um hypoxische Zellen zu erhalten. Die Begasung wurde auch während der Bestrahlung nicht unterbrochen.

Eine schematische Darstellung des Versuchsaufbaus ist in Abbildung 4 zu sehen. 


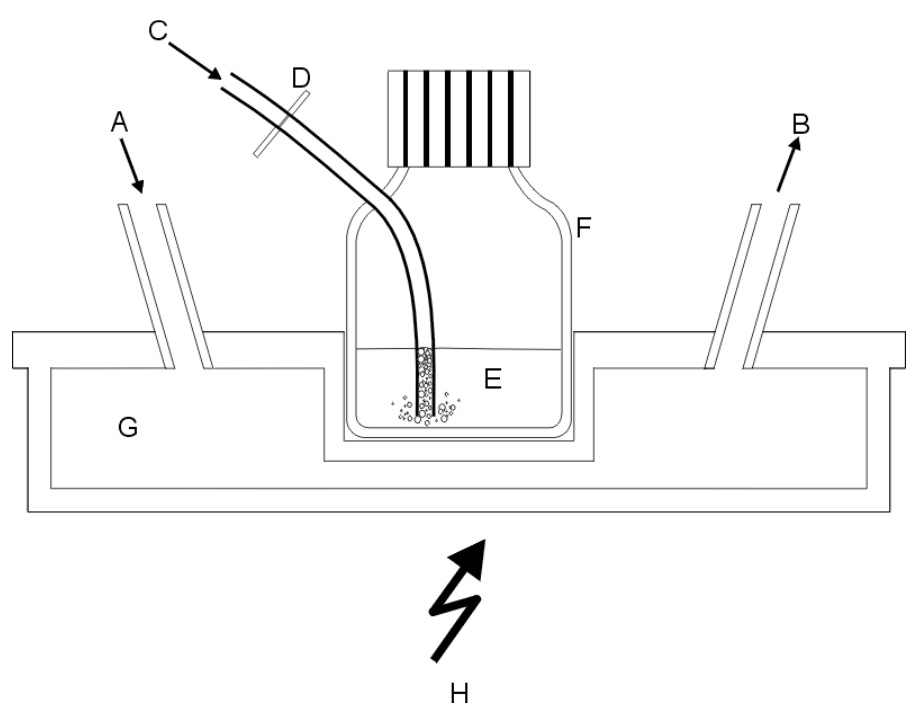
A Kühlwasserzulauf
B Kühlwasserablauf
C Gaszufuhr
D Sterilfilter
E $8 \mathrm{ml}$ Hefezellensuspension
F Bestrahlungsgefäß aus Glas
$\mathrm{G}$ Kühlwasser $4{ }^{\circ} \mathrm{C}$
H Röntgenstrahlung 200 kVp

Abbildung 4: Schematische Darstellung des Bestrahlungsaufbaus

Die Bestrahlung mit Röntgenstrahlen erfolgte mit einem Stabilipan-Röntgengerät (Röhrenspannung 200 kVp, Cu-Filter 0,5 mm, Stromstärke 20 mA, Gleichmäßigkeit der Feldausleuchtung >98\%) der Fa. Siemens bei einer Dosisrate von 15 Gy $\times \mathrm{min}^{-1}$. Es wurden Strahlendosen von 150, 200 und 300 Gy appliziert. In regelmäßigen Abständen wurde eine Eisensulfat-Dosimetrie durchgeführt (DIN 6800, Teil 3) (Normenausschuß Radiologie im DIN, Normenausschuß Kerntechnik im DIN 1980). Der Fehler der Dosismessung bewegte sich hierbei im 1\%-Bereich.

\subsection{Reparaturversuche}

Nach der Bestrahlung bzw. nach kombinierter Behandlung mit Cisplatin und Bestrahlung wurden die Zellen in Phosphatpuffer, das in dieser Arbeit auch als NWM bezeichnet wird, auf ca. $1,0 \times 10^{8}$ Zellen/ml verdünnt und unter Schütteln bei $23^{\circ} \mathrm{C}$, der permissiven Temperatur für die DSB-Reparatur, inkubiert. Zur Ermittlung der Reparaturkinetik von DSB in bestrahlten bzw. vorher zusätzlich Cisplatin-behandelten Zellen wurden jeweils 0, 2, 4, 6, 24 und 48 Stunden nach Bestrahlung Proben zu je $4 \times 10^{8}$ Zellen entnommen.

2.7 Bestimmung der DNA-Doppelstrangbrüche mittels Pulsfeldgelelektrophorese

\subsubsection{Probenaufbereitung und Herstellung von Agaroseblöckchen}

Die Probenaufbereitung erfolgte im Wesentlichen nach der Methode von Mortimer et al. (1992). Für jeden Messpunkt wurde eine Probe von $4 \times 10^{8}$ Zellen benötigt, die durch 


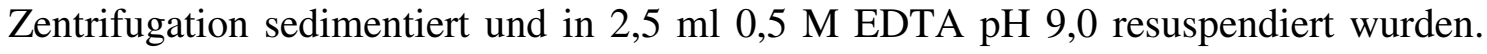
Unter diesen Bedingungen wird die Fragmentierung der DNA durch Nukleasen gehemmt, deren Aktivität von zweiwertigen Ionen abhängt, die durch das EDTA komplexiert werden. Die Zellsuspension wurde erneut zentrifugiert, die Zellen in $1 \mathrm{ml}$ SCE (1 M Sorbitol, 0,1 M Natriumcitrat, 10 mM EDTA pH 7,5) suspendiert und in ein Eppendorf-Röhrchen überführt. Die Zellwände der Hefen wurden durch Lyticase (Endkonzentration $250 \mathrm{U} / \mathrm{ml}$, Fa. Sigma) während einer 30 minütigen Inkubation im Wasserbad ohne Schütteln angedaut und zwar bei $36^{\circ} \mathrm{C}$, so dass die Reparatur von DSB während dieser Zeit nicht möglich war. Danach wurden die Proben bei $4^{\circ} \mathrm{C}$ für 5 Minuten mit nur 2000×g (Mikro-Rapid/K 1306, Fa. Hettich) zentrifugiert, um die fragilen Sphäroblasten zu schonen. Die sedimentierten Sphäroblasten (ca. $70 \mu \mathrm{l}$ ) wurden mit $430 \mu \mathrm{l}$ Sorbit+EDTA (1 M Sorbit, 0,5 M EDTA) versetzt und mit einer abgeschnittenen und abgerundeten sterilen Eppendorf-Spitze vorsichtig resuspendiert. Diese Suspension $(500 \mu \mathrm{l})$ wurde mit einem gleichem Volumen auf $40^{\circ} \mathrm{C}$ erwärmter 2\%iger Agarose (Low Melting Point (LMP)-Agarose, Typ A-9414, Fa. Sigma, gelöst in 0,125 M EDTA, pH 7,8) gemischt, so dass die Sphäroblasten in einer 1\%igen LMP-

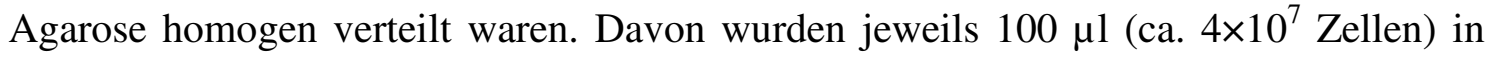
rechteckige Vertiefungen einer auf Eistemperatur gekühlten Plastikform pipettiert und mindestens 10 Minuten auf Eis belassen, bis die Agaroseblöckchen erstarrt waren. Danach wurden die Blöckchen in 2,5 ml ES (0,5 M EDTA, 1\% N-Laurylsarcosine, pH 9,5) überführt, das mit $1 \mathrm{mg} / \mathrm{ml}$ Proteinase K versetzt war. Darin wurden die Blöckchen 16-20 Stunden im $50^{\circ} \mathrm{C}$-Wasserbad unter leichtem Schütteln inkubiert, um die Zellmembranen und Proteine zu verdauen. Nach dieser Behandlung lag die von allen übrigen Zellbestandteilen befreite DNA in einer Agarose-Matrix vor Scherkräften geschützt vor, so dass keine artifiziellen DSB auftreten konnten. Anschließend wurden die Blöckchen dreimal mit jeweils 2,5 ml TE 50 (10 mM Tris-HCl, 50 mM EDTA, pH 7,5) gewaschen und für ca. 6 Stunden bei $30^{\circ} \mathrm{C}$ inkubiert, wobei alle 1,5 Stunden TE 50 erneuert wurde. Nach dem letzten Waschen wurden die Blöckchen bei $4^{\circ} \mathrm{C}$ in TE 50 aufbewahrt bis zum Einsatz für die Gelelektrophorese.

\subsubsection{Herstellung eines Agarosegels und Einbetten der Agaroseblöckchen}

Für die Herstellung eines 1\%igen Agarosegels wurde 1 g Agarose (Typ A-9539, Fa. Sigma) in $100 \mathrm{ml}$ 0,5×TBE (45 mM Tris Base, $45 \mathrm{mM}$ Borsäure, $1 \mathrm{mM}$ EDTA, pH 8,0) durch Erhitzen gelöst, die Lösung auf ca. $60^{\circ} \mathrm{C}$ abgekühlt und dann in einen 
Gelgießstand gegossen, der sich auf einer waagrechten Unterlage befand. Die Abmessung des Gels betrug $120 \times 145 \times 6$ mm, an einer der kurzen Seiten wurden durch einen eingesteckten Kamm zehn Geltaschen für die Blöckchen ausgespart. Nach Abkühlen des Gels wurde der Kamm entfernt, die Blöckchen in die Geltaschen mit einem abgeflammten Spatel hochkant eingebettet und mit 1\%iger Agaroselösung (Typ A-9414, Fa. Sigma, gelöst in 0,125 M EDTA; pH 7,8) versiegelt.

\subsubsection{Auftrennung von DNA-Molekülen nach ihrer Größe mittels Pulsfeldgelelektrophorese}

Konventionelle Elektrophorese kann DNA-Moleküle nur bis zu einer Größe von 75.000 Basenpaaren (75 kBp) auftrennen (Fangman 1978). Mit der Pulsfeldgelelektrophorese (PFGE), die auf dem Prinzip eines in der Richtung alternierenden elektrischen Feldes beruht, wurde eine Methode entwickelt, mit der die 16 Chromosomen einer haploiden Zelle der Hefe Saccharomyces cerevisiae (0,2-2 MBp) aufgetrennt werden können (Schwartz und Cantor 1984, Carle und Olsen 1986). Die nukleäre DNA beträgt insgesamt ca. $9 \times 10^{9}$ Daltons, wobei das größte Chromosom 1,5-2,2×10 ${ }^{9}$ Daltons ausmacht. Jedes Chromosom enthält nur ein DNA-Molekül (Lauer et al. 1977). Chu et al. stellten 1986 mit dem CHEF-System eine besondere Form der PFGE vor, die mit multiplen Elektroden ein homogenes alternierendes elektrisches Feld aufbaut, mit dem eine bessere Auftrennung der chromosomalen DNA-Moleküle nach ihrer Größe möglich ist. Mit einer neueren Version des CHEF-Systems wird die Darstellung der DNA-Banden noch schärfer, besser voneinander abgrenzbar und nur noch geringfügig verzerrt (Chu 1989). Die alternierenden elektrischen Felder befinden sich hier in einem Winkel von $120^{\circ}$ zueinander. In Abbildung 5 wird das Prinzip dieses Systems dargestellt. 
I.

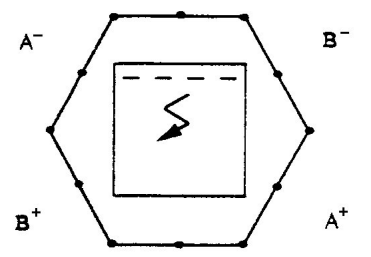

II.
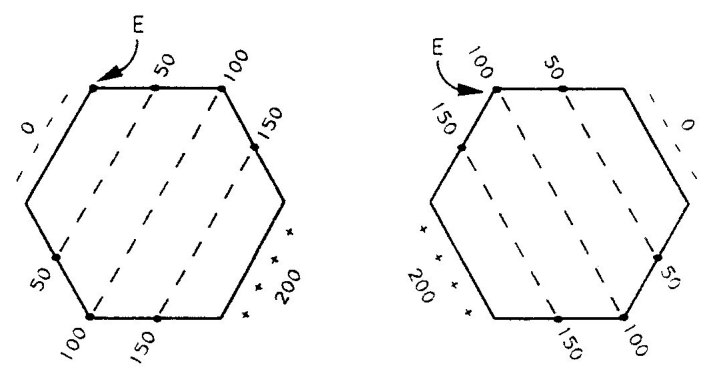

Abbildung 5: Prinzip der CHEF-Elektrophorese: I. zeigt eine hexagonale Anordnung von Elektroden, die ein Gel umgeben. Ein Punkt repräsentiert eine einzelne Elektrode. Die korrespondierenden Paare, die das alternierende elektrische Feld aufbauen $\left(\mathrm{A}^{+}\right.$und $\mathrm{A}^{-}, \mathrm{B}^{+}$und $\mathrm{B}^{-}$), stehen im Winkel von $120^{\circ}$ zueinander. Die Pulszeit beschreibt die Dauer, in der das elektrische Potential zwischen einem Elektrodenpaar besteht. Die negativ geladenen DNA-Moleküle beschreiben eine Zickzackbewegung im Gel, indem sie sich mit jedem Wechsel des elektrischen Feldes in Richtung Anode reorientieren, der Gesamtvektor der Bewegung ist jedoch gerade. II. zeigt die Linien gleicher Feldstärke (Vollrath 1992, S. 20).

In der vorliegenden Arbeit wurde das CHEF-DR II System, Fa. BioRad, verwendet, bestehend aus der Elektrophoresekammer, Stromversorgung, Steuergerät und dem Kryostat Typ 1000 Fa. BioRad mit Durchflusspumpe. Der Elektrophoresetank wurde mit 2000 ml Laufpuffer (0,5×TBE) gefüllt. Das Gel mit den Agaroseblöckchen wurde mittels einer Grundplatte oder vier Halterungen in der Elektrophoresekammer fixiert. Der Laufpuffer wurde über den Kryostaten auf $14^{\circ} \mathrm{C}$ gekühlt und die Läufe erst bei Erreichen dieser Temperatur gestartet.

Die Elektrophorese lief über 22-24 Stunden bei einer Spannung von 200 Volt (Feldstärke 7,4 V/cm). In den ersten 9 Stunden wechselte die Richtung des elektrischen Feldes alle 60 Sekunden, in den folgenden 13-15 Stunden erfolgte der Richtungswechsel alle 90 Sekunden. Neben verschiedenen anderen Faktoren (Konzentration des Gels, Lauftemperatur, Laufpufferkonzentration, elektrische 
Feldstärke, Zellkonzentration im Agaroseblöckchen) nimmt die Pulszeit entscheidenden Einfluss auf die Migration der DNA im Gel (Ager et al. 1990, Blöcher und Kunhi 1990). Je länger die Pulszeit, d. h. je seltener der Richtungswechsel des elektrischen Feldes, desto besser ist die Auftrennung größerer DNA-Moleküle. Die 1. Pulszeit von 60 Sekunden führt also zu einer besseren Migration der kleineren Hefechromosomen, die 2. Pulszeit von 90 Sekunden ist für die Migration der größeren Hefechromosomen günstiger.

\subsubsection{Darstellung der DNA mittels Ethidiumbromid}

Nach Beendigung der PFGE wurde die DNA im Gel mittels Ethidiumbromid (EtBr) angefärbt. Dazu wurde das Gel in $200 \mathrm{ml} \mathrm{0,25 \times TBE-Laufpuffer}$ mit 0,5 $\mu \mathrm{g} / \mathrm{ml} \mathrm{EtBr} 45$ Minuten unter leichtem Schütteln behandelt. Da sich EtBr bei Lichteinfluß zersetzt, wurde die Färbung im Dunkeln durchgeführt. Anschließend wurde das Gel zweimal mit $200 \mathrm{ml}$ 0,25×TBE gespült und danach drei Stunden in $200 \mathrm{ml} \mathrm{0,25 \times TBE} \mathrm{mit} 1 \mu \mathrm{g} / \mathrm{ml}$ RNAse bei $37^{\circ} \mathrm{C}$ unter leichtem Schütteln inkubiert. Die RNAse diente zum Abbau der RNA, die EtBR ebenfalls bindet, wenn auch wesentlich schwächer als die doppelsträngige DNA.

2.7.5 Quantitative densitometrische Auswertungsmethoden mittels konventioneller vs. digitaler Fotografie

Die mittels CHEF-Elektrophorese im Gel nach ihrer Größe aufgetrennten DNAMoleküle wurden durch das an die DNA gebundene EtBr unter Bestrahlung mit UVLicht dargestellt. Bei der Aufnahme mittels konventioneller Fotografie wurde zur Anregung der Transilluminator Typ IL-200 M, $\lambda=302$ nm (Fa. Bachofer) verwendet. Die Fotoeinheit bestand aus einer Plattenkamera $18 \times 24 \mathrm{~cm}$ (Fa. Linhof), Objektiv 1:9/360 mm (Apo-Artar) und Orange-Filter Typ 023 3× (Fa. B+W). Es wurden s/wNegativ-Filme Typ FP-4 plus 125, ISO $125 / 22^{\circ}$ (Fa. Ilford) verwendet, die Belichtungszeit betrug drei Minuten. Die Negative wurden nach Standardbedingungen mit einem Feinstkornentwickler entwickelt. Die Negativbilder wurden dann mit einer Still-Video-Kamera Typ Ion RC-260 (Fa. Canon) aufgenommen und mit einem Framegrabber Typ QuickImage ${ }^{\mathrm{TM}} 24$ (Fa. Mass Microsystems), eingesetzt in einem Apple Macintosh Quadra 700, digitalisiert. Abbildung 6 zeigt ein exemplarisches Positivfoto eines Gels. 


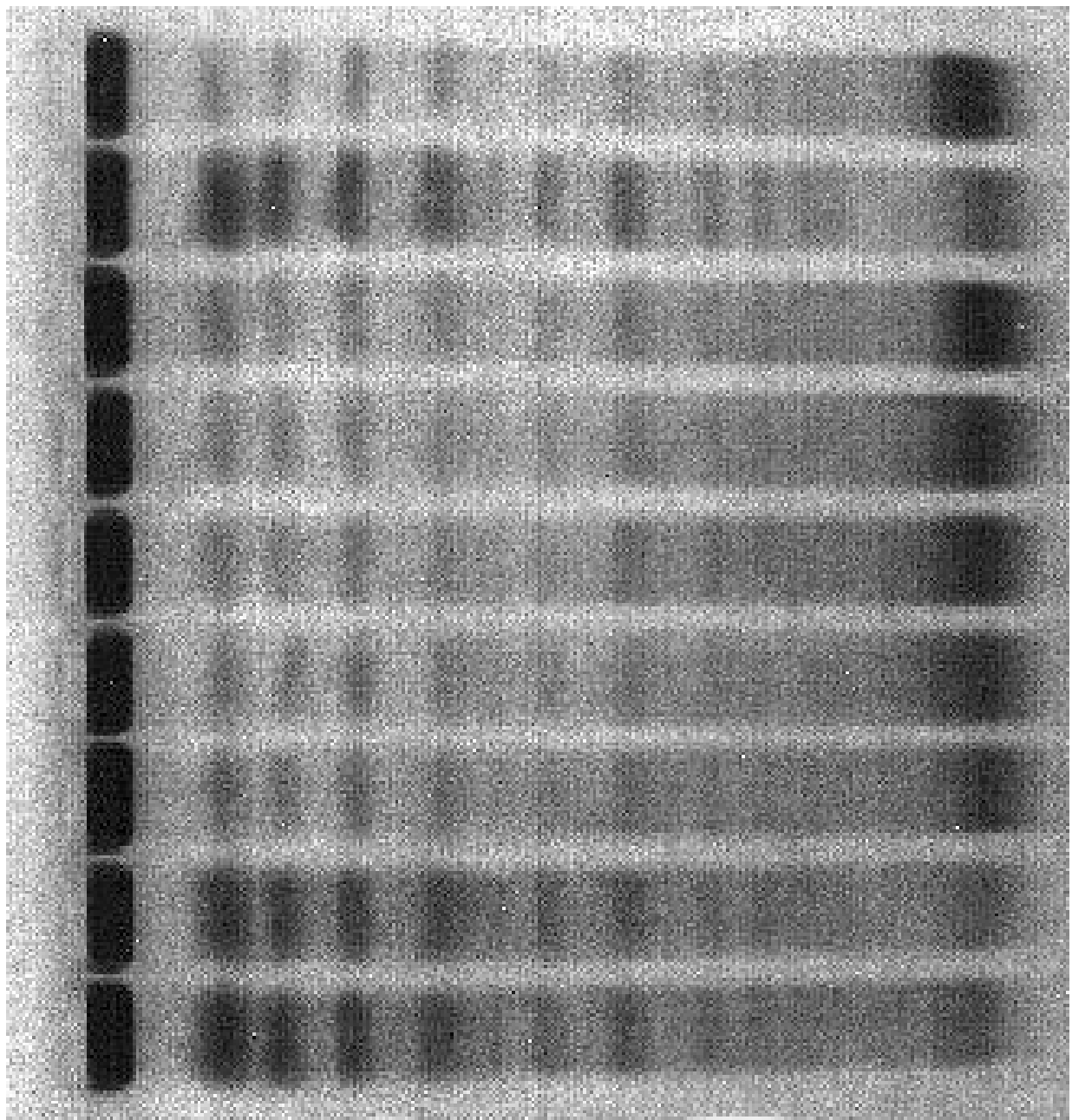

Migrationsrichtung DNA

Abbildung 6: Exemplarisches Positivfoto eines Gels. Die einzelnen DNA-Spuren, die zu einem Agarose-Blöckchen gehören, verlaufen horizontal. Die abgrenzbaren DNABanden stellen Hefechromosomen dar.

Alternativ wurde die Aufnahme des Gels mit einer CCD-Kamera Typ CF 8/1, s/w, 752×582 Pixel Auflösung (Fa. Kappa), Objektiv Typ Fujinon TV HF16-A2, 1:1.4/16 mm (Fa. Fuji) und Orange-Filter Typ DNA (Fa. Herolab) durchgeführt, hierbei wurde der UV-Transilluminator Typ UVT 2035, $\lambda=312 \mathrm{~nm}$ (Fa. Herolab) benutzt. Die Zwischenspeicherung des Bildes erfolgte im Steuergerät der Kamera, Typ MFC (Fa. Kappa). Die Digitalisierung erfolgte auch hier mit dem Framegrabber Typ QuickImage $^{\mathrm{TM}} 24$ (Fa. Mass Microsystems) in einem Apple Macintosh Quadra 700.

Die digitalisierten Bilder beider Aufnahmemethoden wurden in einer Auflösung von 768×576 Pixel und 256 Graustufen im Bildformat Macintosh PICT abgespeichert und mit Hilfe des Programms NIH-Image, Version 1.60 für Macintosh, ausgewertet. 
Mit dem Gel Plotting Macro wurden die Graustufenprofile jeder DNA-Spur dargestellt (Abb. 7). Der Hintergrund des Agarose-Gels wurde anhand einer Leerspur bestimmt, und dieser Wert wurde von allen DNA-Spuren abgezogen. Die aus den Blöckchen während der Elektrophorese herausgewanderte DNA wurde als Integral der Fläche der Profilkurve über dem Hintergrund quantifiziert und der relative Anteil der 1. Bande am Gesamtintegral (rel.DNA1) wurde errechnet. Pro Gel liefen zwei Kontrollproben des gleichen Versuches mit, deren Auswertung der DNA-Profile den entsprechenden Kontrollwert (rel.DNA1K) lieferte.

Die Auswertung mittels elektronischer Bildverarbeitung basiert auf dem Vergleich der relativen Fläche unter der 1. DNA-Bande der behandelten Zellen mit der der unbehandelten Kontrollzellen. Die 1. DNA-Bande entspricht den am langsamsten in das Gel gewanderten, somit längsten DNA-Molekülen der Hefe. Es wurde speziell die 1. DNA-Bande für die Bestimmung von DSB herangezogen, da die Abnahme der Intensität der 1. DNA-Bande nur bedingt ist durch die Fragmentierung der längsten DNA-Moleküle, im Gegensatz dazu zeigen die 2. DNA-Bande und in zunehmendem Maße alle folgenden DNA-Banden sowohl eine Intensitätsabnahme infolge Fragmentierung ihrer jeweiligen DNA-Moleküle als auch eine Intensitätszunahme durch Fragmente größerer DNA-Moleküle. Ein Vergleich mit einem BioRad-HefeStandard ergab, dass die 1. Bande DNA der Chromosomen XII (2200 kbp) und IV (1600 kbp) enthält. Die Anzahl der DSB wurde deshalb auf eine mittlere DNA-Länge von 1900 kbp bezogen. Die Abnahme der relativen Fläche der 1. DNA-Bande durch DSB nach Cisplatin-Einwirkung bzw. Bestrahlung ist ein Maß für die Anzahl der DSB. Unter der Annahme einer statistischen Verteilung der DSB wurde die Anzahl der DSB pro DNA-Molekül (1900 kbp) unter der 1. Bande $\left(\mathrm{DSB} \times 1\right.$. Bande $\left.{ }^{-1}\right)$ nach Gleichung 1 berechnet.

Gleichung 1

$$
\mathrm{DSB} \times 1 . \text { Bande }^{-1}=-\ln \frac{\text { rel.DNA1 }}{\text { rel.DNA1K }}
$$




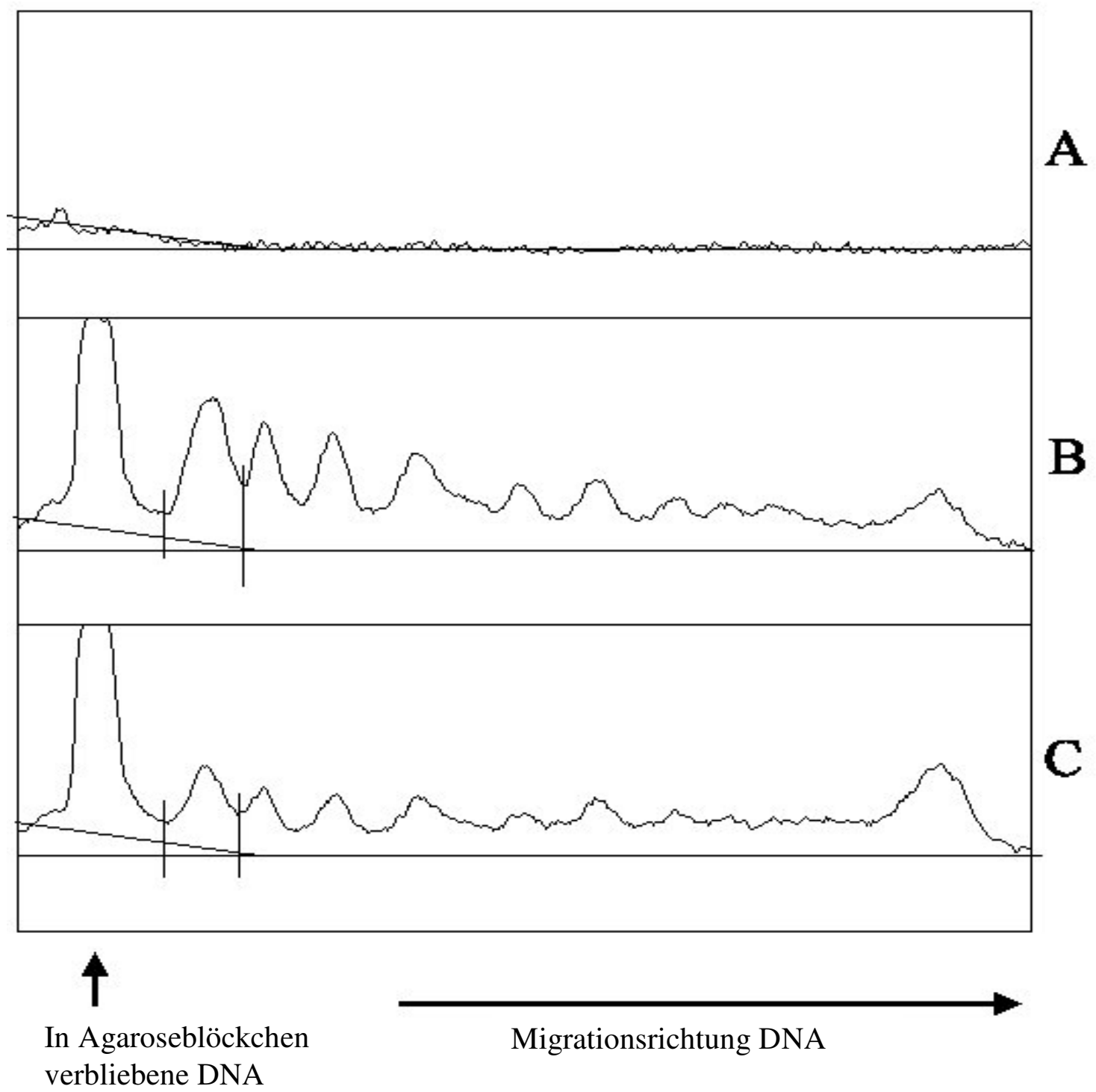

Abbildung 7: Exemplarische Darstellung einer Leerspur und zweier DNA-Spuren nach Bearbeitung mit dem Programm NIH-Image. Die Leerspur A (Agarose-Gel ohne DNA) wird als Hintergrund von allen anderen Spuren abgezogen. B ist die DNA-Spur unbehandelter Zellen, auf deren relativen Anteil der 1. Bande am Gesamtintegral man sich bezieht. Die Spur C stellt die DNA-Verteilung einer Cisplatin-behandelten Probe nach anschließender 24stündiger Akkumulation von DSB dar. Die Abnahme der relativen Fläche unter dem 1. Peak im Vergleich zur Kontrolle weist auf das Auftreten von DSB hin.

Die Ergebnisse beider Aufnahmemethoden wurden abschließend statistisch verglichen, um zu testen, ob quantitative Unterschiede vorliegen, die z. B. aus der nicht-linearen 
Beziehung zwischen der emittierten Lichtintensität und der Schwärzung des Films bei der konventionellen fotografischen Aufnahme resultieren könnten. Hierbei wurde der Wilcoxon-Vorzeichenrangtest (nach Hartung et al. 1987) verwendet. 


\section{Ergebnisse}

3.1 Induktion und Reparaturkinetik von Doppelstrangbrüchen nach Bestrahlung hypoxischer Hefezellen

Hypoxische Zellen wurden mit Dosen von 200 Gy bzw. 300 Gy bestrahlt und die Reparatur der strahleninduzierten DSB während der Inkubation der Zellen in NWM bei $23^{\circ} \mathrm{C}$, der permissiven Temperatur für die DSB-Reparatur, untersucht. Abbildung 8 zeigt die Induktion der DSB in Abhängigkeit von diesen Dosen. Bei 200 Gy wurden im Mittel pro 1. Bande $0.21 \pm 0.09$ DSB induziert, bei 300 Gy $0.27 \pm 0.07$ DSB (Tabelle 1 und 2).

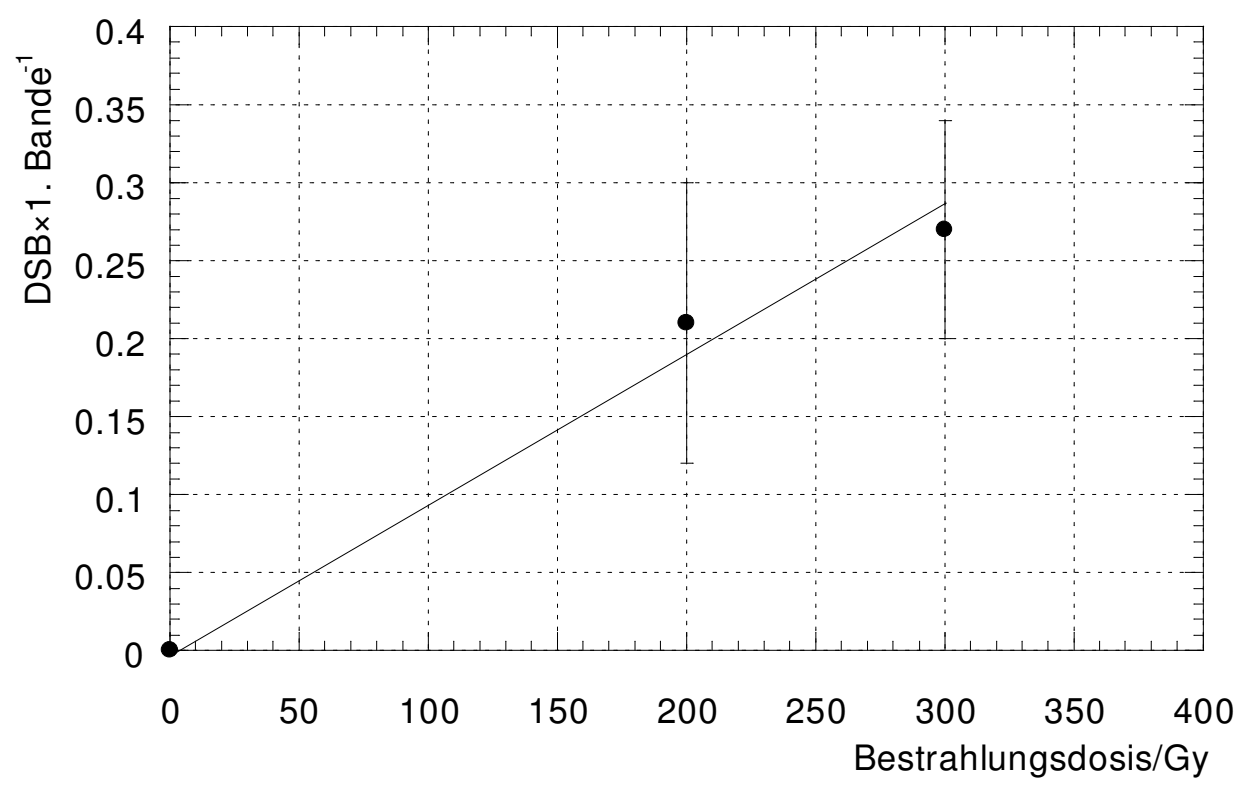

Abbildung 8: Anzahl der DSB $\times 1$. Bande ${ }^{-1}$ nach Bestrahlung hypoxischer Zellen der Hefemutante rad54-3 mit 200 Gy bzw. 300 Gy. Es sind die Mittelwerte (•) von jeweils 11 Versuchen mit den entsprechenden Standardabweichungen aufgetragen.

Die Ergebnisse der Reparaturversuche nach den Reparaturzeiten 0, 2, 4, 6, 24 und 48 Stunden sind in Tabelle 1 bzw. 2 für die verschiedenen Experimente aufgelistet, mit dem Mittelwert x und der Standardabweichung s. In Abbildung 9 bzw 10 sind diese Ergebnisse grafisch dargestellt für die Dosen 200 bzw. 300 Gy. 


\begin{tabular}{|c|c|c|c|c|c|c|c|c|c|c|c|c|c|}
\hline $\begin{array}{l}\text { Reparatur- } \\
\text { zeit/h }\end{array}$ & \begin{tabular}{|l} 
Exp. \\
Nr.1
\end{tabular} & 2 & 3 & 4 & 5 & 6 & 7 & 8 & 9 & 10 & 11 & $\mathrm{x}$ & $\mathrm{s}$ \\
\hline $\begin{array}{l}\text { Kontrollen, } \\
\mathrm{N}_{2} \text {-begast }\end{array}$ & 0,13 & $-0,07$ & $-0,11$ & 0,06 & 0,00 & 0,06 & 0,13 & 0,10 & 0,00 & 0,00 & 0,10 & 0,04 & 0,08 \\
\hline $200 \mathrm{~Gy}, 0$ & 0,19 & 0,20 & 0,12 & 0,37 & 0,06 & 0,18 & 0,27 & 0,32 & 0,21 & 0,16 & 0,24 & 0,21 & 0,09 \\
\hline $200 \mathrm{~Gy}, 2$ & 0,19 & 0,03 & 0,12 & 0,58 & 0,21 & 0,12 & 0,06 & 0,24 & 0,21 & & 0,24 & 0,20 & 0,15 \\
\hline 200 Gy, 4 & 0,19 & 0,03 & 0,18 & 0,37 & 0,21 & 0,18 & 0,13 & 0,10 & 0,13 & & 0,16 & 0,17 & 0,09 \\
\hline 200 Gy, 6 & 0,19 & 0,20 & 0,18 & 0,29 & 0,13 & 0,25 & $-0,06$ & 0,16 & 0,21 & & 0,16 & 0,17 & 0,09 \\
\hline 200 Gy, 24 & 0,06 & $-0,03$ & 0,06 & 0,13 & 0,06 & 0,00 & $-0,11$ & $-0,03$ & 0,13 & & 0,16 & 0,04 & 0,09 \\
\hline 200 Gy, 48 & 0,19 & 0,08 & 0,25 & 0,13 & 0,06 & 0,06 & 0,00 & 0,10 & 0,21 & & 0,03 & 0,11 & 0,08 \\
\hline
\end{tabular}

Tabelle 1: Anzahl der DSB $\times 1$. Bande ${ }^{-1}$ nach Bestrahlung hypoxischer Zellen der Hefemutante rad54-3 mit 200 Gy und anschließender Reparatur unter Nichtwuchsbedingungen bei $23^{\circ} \mathrm{C}$ (x: arithmetischer Mittelwert; s: Standardabweichung, Kontrollen: unbestrahlte Zellen nach 20minütiger Hypoxie). Wegen technischer Gründe (zu niedrige Zellzahlen) konnten nicht alle Ergebnisse des Experiments Nr. 10 verwendet werden.

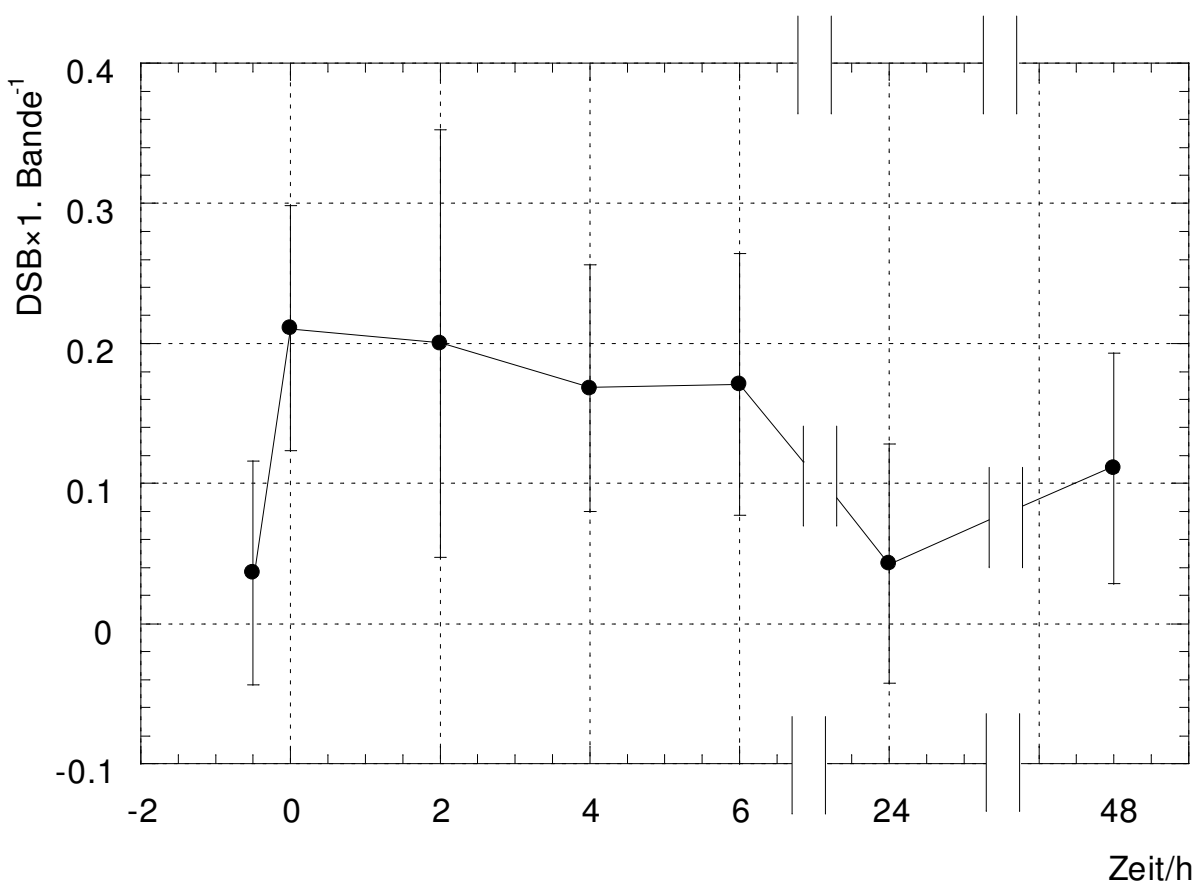

Abbildung 9: Kinetik der Reparatur von DSB nach Bestrahlung hypoxischer Zellen der Hefemutante rad54-3 mit 200 Gy. Die Reparatur erfolgte unter Nichtwuchsbedingungen bei $23^{\circ} \mathrm{C}$. Die Anzahl der DSB $\times 1$. Bande ${ }^{-1}$ ist in Abhängigkeit 
von der Reparaturzeit aufgetragen. Es sind die Mittelwerte (O) von 11 Versuchen mit den entsprechenden Standardabweichungen angegeben.

\begin{tabular}{|c|c|c|c|c|c|c|c|c|c|c|c|c|c|}
\hline Reparaturzeit/h & Exp. Nr.1 & 2 & 3 & 4 & 5 & 6 & 7 & 8 & 9 & 10 & 11 & $\mathrm{x}$ & $\mathrm{s}$ \\
\hline Kontrollen, $\mathrm{N}_{2}$-begast & 0,07 & $-0,13$ & 0,05 & 0,02 & 0,05 & $-0,03$ & 0,03 & 0,17 & 0,05 & 0,00 & $-0,03$ & 0,02 & 0,07 \\
\hline $300 \mathrm{~Gy}, 0$ & 0,30 & 0,22 & 0,22 & 0,31 & 0,29 & 0,20 & 0,43 & 0,17 & 0,34 & 0,27 & 0,26 & 0,27 & 0,07 \\
\hline $300 \mathrm{~Gy}, 2$ & 0,30 & 0,22 & 0,22 & 0,19 & 0,11 & 0,14 & 0,35 & 0,05 & 0,27 & 0,10 & 0,18 & 0,19 & 0,09 \\
\hline 300 Gy, 4 & 0,30 & 0,22 & 0,22 & 0,19 & 0,05 & 0,20 & 0,21 & 0,17 & 0,15 & 0,15 & 0,10 & 0,18 & 0,07 \\
\hline 300 Gy, 6 & 0,18 & 0,09 & 0,16 & 0,38 & $-0,05$ & 0,14 & 0,03 & 0,05 & 0,10 & 0,10 & 0,18 & 0,12 & 0,11 \\
\hline $300 \mathrm{~Gy}, 24$ & 0,18 & 0,09 & 0,16 & & $-0,10$ & 0,14 & 0,15 & 0,11 & 0,10 & 0,05 & 0,10 & 0,10 & 0,08 \\
\hline $300 \mathrm{~Gy}, 48$ & 0,07 & 0,03 & 0,22 & 0,02 & $-0,05$ & 0,08 & 0,03 & $-0,10$ & 0,15 & 0,15 & 0,18 & 0,07 & 0,10 \\
\hline
\end{tabular}

Tabelle 2: Anzahl der DSB $\times 1$. Bande ${ }^{-1}$ nach Bestrahlung hypoxischer Zellen der Hefemutante rad54-3 mit 300 Gy und anschließender Reparatur unter Nichtwuchsbedingungen bei $23^{\circ} \mathrm{C} \quad(\mathrm{x}$ : arithmetischer Mittelwert; s: Standardabweichung, Kontrollen: unbestrahlte Zellen nach 20minütiger Hypoxie). Wegen technischer Gründe (zu niedrige Zellzahlen) konnten nicht alle Ergebnisse des Experiments Nr. 4 verwendet werden.

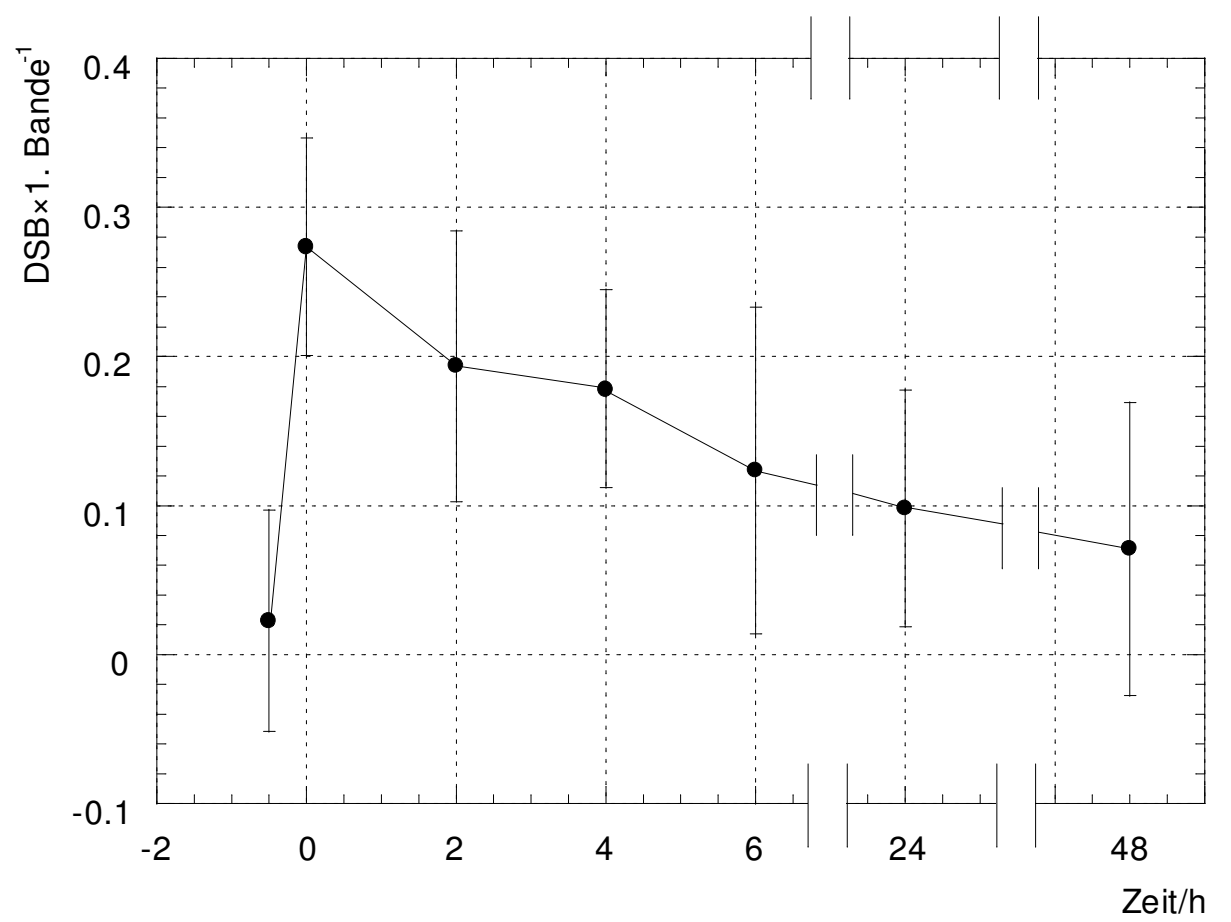

Abbildung 10: Kinetik der Reparatur von DNA-DSB nach Bestrahlung hypoxischer Zellen der Hefemutante rad54-3 mit 300 Gy. Die Reparatur erfolgte unter 
Nichtwuchsbedingungen bei $23^{\circ} \mathrm{C}$. Die Anzahl der DSB $\times 1$. Bande ${ }^{-1}$ ist in Abhängigkeit von der Reparaturzeit aufgetragen. Es sind die Mittelwerte (O) von 11 Versuchen mit den entsprechenden Standardabweichungen angegeben.

Die Ergebnisse der Reparaturkinetik zeigen, dass die DSB $\times 1$. Bande ${ }^{-1}$ nach Bestrahlung hypoxischer Hefezellen mit 200 Gy um den Faktor 5 (von 0.21 DSB $\times 1$. Bande ${ }^{-1}$ auf $0.04 \mathrm{DSB} \times 1$. Bande $^{-1}$ ) nach 24 Stunden Reparaturinkubation abnehmen. Der nach 48 Stunden leichte Anstieg der DSB $\times 1$. Bande ${ }^{-1}$ auf 0.11 ist nicht wesentlich. Nach einer Strahlendosis von 300 Gy werden 0.27 DSB $\times 1$. Bande ${ }^{-1}$ induziert, deren Anzahl nach einer 24stündigen Reparaturinkubation bis auf $0.1 \mathrm{DSB} \times 1$. Bande ${ }^{-1}$ abnimmt. Nach 48 Stunden ist hier eine nicht wesentliche Abnahme auf $0.07 \mathrm{DSB} \times 1$. Bande ${ }^{-1} \mathrm{zu}$ beobachten. Die meist bei $0.07-0.09 \mathrm{DSB} \times 1$. Bande ${ }^{-1}$ liegende relativ große Standardabweichung der einzelnen Mittelwerte macht eine genaue Bestimmung der Halbwertszeiten für die DSB-Reparatur schwierig. Sie beträgt bei Bestrahlung mit 300 Gy ca. 5 h.

\subsection{Induktion von Doppelstrangbrüchen nach Cisplatin-Behandlung von Hefezellen}

Frankenberg-Schwager et al. (2005) konnten zeigen, dass in rad54-3-Zellen, die eine temperaturabhängige Fähigkeit zur DSB-Reparatur aufweisen, DSB infolge einer Cisplatin-Behandlung auftreten. Diese DSB akkumulieren, wenn Zellen nach CisplatinBehandlung in Wuchsmedium (YPD) bei der für die DSB-Reparatur restriktiven Temperatur inkubiert werden und somit keine Abnahme der DSB durch Reparaturprozesse stattfinden kann. Nach 24 Stunden ist das Maximum an DSB erreicht, bei weiterer Inkubation bleibt das Niveau an DSB konstant. Ausgehend von diesen Ergebnissen wurde in der vorliegenden Arbeit eine Kombinationstherapie Cisplatin und Bestrahlung simuliert und auf der Ebene von DSB untersucht.

Zellen der Hefemutante rad54-3 wurden in einer Cisplatin-Lösung für eine Stunde bei der restriktiven Temperatur von $36^{\circ} \mathrm{C}$ inkubiert, bei der keine DSB repariert werden. Frankenberg-Schwager et al. (2005) hatten zuvor gezeigt, dass während der einstündigen Inkubationszeit keine DSB auftreten. Nach der Cisplatin-Behandlung sowie nach der anschließenden 24stündigen Inkubation der Zellen in Wuchsmedium bei $36^{\circ} \mathrm{C}$ wurde eine DSB-Messung durchgeführt. Die Cisplatin-Behandlung sowie die nachfolgende Inkubation wurden unter Oxie durchgeführt. Die Ergebnisse von 24 
Experimenten sind in Tabelle 3 numerisch und in Abbildung 11 als Blockdiagramm dargestellt.

\begin{tabular}{c|c|c} 
Nr. des Experiments & Cis, $1 \mathrm{~h}, 36^{\circ} \mathrm{C}$ & Cis, $1 \mathrm{~h}, 36^{\circ} \mathrm{C}+24 \mathrm{~h} \mathrm{YPD}, 36^{\circ} \mathrm{C}$ \\
\hline 1 & 0,12 & 0,33 \\
2 & 0,13 & 0,47 \\
3 & $-0,03$ & 0,34 \\
4 & 0,35 & 0,35 \\
5 & 0,06 & 0,37 \\
6 & 0,03 & 0,35 \\
7 & 0,08 & 0,52 \\
8 & 0,04 & 0,92 \\
9 & 0,06 & 0,69 \\
10 & 0,18 & 0,69 \\
11 & 0,11 & 0,64 \\
12 & 0,02 & 0,71 \\
13 & 0,00 & 0,63 \\
14 & 0,07 & 0,51 \\
15 & $-0,03$ & 0,38 \\
16 & 0,08 & 0,25 \\
17 & $-0,03$ & 0,34 \\
18 & 0,05 & 0,60 \\
19 & 0,03 & 0,43 \\
20 & 0,09 & 0,66 \\
21 & 0,00 & 0,37 \\
22 & 0,03 & 0,30 \\
23 & 0,17 & 0,46 \\
24 & 0,00 & 0,53 \\
\hline $\mathrm{x}$ & 0,10 & 0,49 \\
$\mathrm{~s}$ & 0,08 & 0,17
\end{tabular}

Tabelle 3: Anzahl der DSB $\times 1$. Bande ${ }^{-1}$ in Cisplatin-behandelten Zellen und anschließender 24 stündiger Inkubation in YPD bei $36^{\circ} \mathrm{C}$. (x: arithmetischer Mittelwert, s: Standardabweichung, 1. Spalte: nur Cisplatin-Behandlung, 2. Spalte: CisplatinBehandlung und 24stündige Inkubation in YPD bei $36^{\circ} \mathrm{C}$ ). 


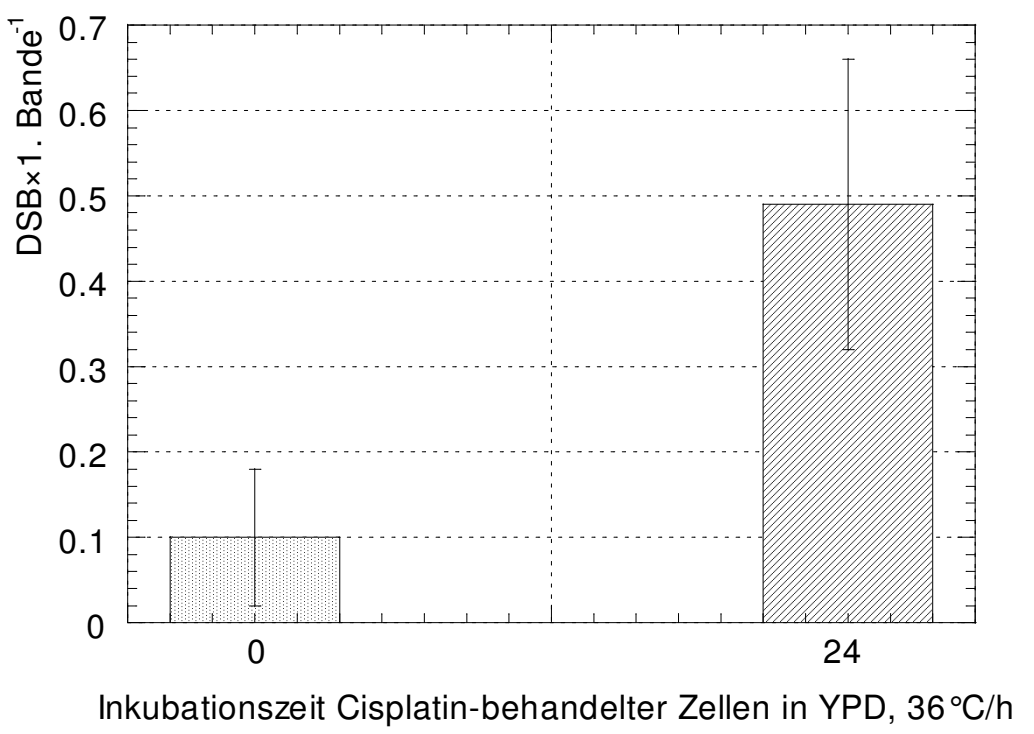

Abbildung 11: Akkumulation von DSB während einer 24stündigen Inkubation in Wuchsmedium bei $36^{\circ} \mathrm{C}$. Die Anzahl ist in Abhängigkeit von der Inkubationszeit aufgetragen. Es sind die Mittelwerte von 24 Versuchen mit den entsprechenden Standardabweichungen angegeben.

3.3 Reparaturkinetik von Doppelstrangbrüchen nach kombinierter Behandlung mit Cisplatin und Bestrahlung

Für die Kombinationsversuche wurden die Zellen zunächst eine Stunde bei $36^{\circ} \mathrm{C}$ mit Cisplatin behandelt und danach 24 Stunden bei $36^{\circ} \mathrm{C}$ unter Wuchsbedingungen inkubiert, um eine Akkumulation der Cisplatin-bedingten DSB zu erreichen (siehe 3.2). Da aus der Literatur bekannt ist, dass bei kombinierter Behandlung mit Cisplatin und Bestrahlung eine verstärkte Wirkung vorliegt, wenn hypoxische statt oxische Zellen bestrahlt wurden (Carde und Laval 1981, Korbelik und Skov 1989), sind in den vorliegenden Experimenten alle Bestrahlungen an hypoxischen Zellen durchgeführt worden. Dazu wurden die Zellen in $20^{\circ} \mathrm{C}$ warmen Puffer überführt und unter Kühlung mittels $4^{\circ} \mathrm{C}$ kalten Wassers 20 Minuten vor und während der Bestrahlung mit $\mathrm{N}_{2}$ begast. Die hypoxischen Zellen wurden mit Dosen von 150, 200 und 300 Gy bestrahlt und die Kinetiken der DSB-Reparatur von 0 - 48 Stunden während der Inkubation der Zellen in NWM bei $23^{\circ} \mathrm{C}$ gemessen. Dabei handelte es sich zum einen um DSB, die nach Cisplatin-Behandlung auftreten, zum anderen um strahleninduzierte DSB. 
Die Ergebnisse der Reparaturversuche nach Bestrahlung Cisplatin-behandelter Zellen mit einer Dosis von 150 Gy sind in Tabelle 4 dargestellt.

\begin{tabular}{l|rrrrrr|r|r} 
Reparaturzeit/h & Exp. Nr. 1 & 2 & 3 & 4 & 5 & 6 & $\mathrm{x}$ & $\mathrm{s}$ \\
\hline Cis, $1 \mathrm{~h}, 36^{\circ} \mathrm{C}$ & 0,12 & 0,13 & $-0,03$ & 0,35 & 0,06 & 0,03 & 0,11 & 0,13 \\
Cis, $1 \mathrm{~h}, 36^{\circ} \mathrm{C}+24 \mathrm{~h} \mathrm{YPD}, 36^{\circ} \mathrm{C}$ & 0,33 & 0,47 & 0,34 & 0,35 & 0,37 & 0,35 & 0,37 & 0,05 \\
Cis, $1 \mathrm{~h}, 36^{\circ} \mathrm{C}+24 \mathrm{~h} \mathrm{YPD}, 36^{\circ} \mathrm{C}+\mathrm{N}_{2}$ & 0,33 & 0,58 & 0,65 & 0,53 & 0,37 & 0,62 & 0,51 & 0,13 \\
\hline Cis + $150 \mathrm{~Gy}$, Reparatur 0 h & 0,41 & 0,47 & 0,85 & 0,75 & 0,58 & 0,62 & 0,61 & 0,17 \\
Cis + $150 \mathrm{~Gy}$, Reparatur 2 h & 0,49 & 0,47 & 0,48 & 0,63 & 0,47 & 0,72 & 0,54 & 0,11 \\
Cis + $150 \mathrm{~Gy}$, Reparatur 4 h & 0,25 & 0,58 & 0,65 & 0,89 & 0,29 & 0,62 & 0,55 & 0,24 \\
Cis + $150 \mathrm{~Gy}$, Reparatur 6 h & 0,18 & 0,98 & 0,97 & 0,75 & 0,37 & 0,72 & 0,66 & 0,32 \\
Cis + $150 \mathrm{~Gy}$, Reparatur 24 h & 0,35 & 0,50 & 0,34 & 0,41 & 0,52 & 0,20 & 0,39 & 0,12 \\
Cis + $150 \mathrm{~Gy}$, Reparatur 48 h & 0,03 & 0,32 & 0,26 & 0,22 & 0,20 & 0,16 & 0,20 & 0,10
\end{tabular}

Tabelle 4: Anzahl der DSB $\times 1$. Bande ${ }^{-1}$ nach kombinierter Behandlung der Hefemutante rad54-3 mit Cisplatin (Cis), Bestrahlung hypoxischer Zellen mit 150 Gy und anschließender Reparatur unter Nichtwuchsbedingungen bei $23^{\circ} \mathrm{C}$ (x: arithmetischer Mittelwert; s: Standardabweichung; die ersten drei Reihen zeigen die Ergebnisse nach Cisplatin-Behandlung (1.), Akkumulation von DSB in YPD bei $36^{\circ} \mathrm{C}$ (2.) und nachfolgender 20minütiger $\mathrm{N}_{2}$-Begasung (3.), die übrigen Reihen stellen die Ergebnisse der Reparatur von DSB nach kombinierter Behandlung mit Cisplatin und Bestrahlung mit 150 Gy dar). 


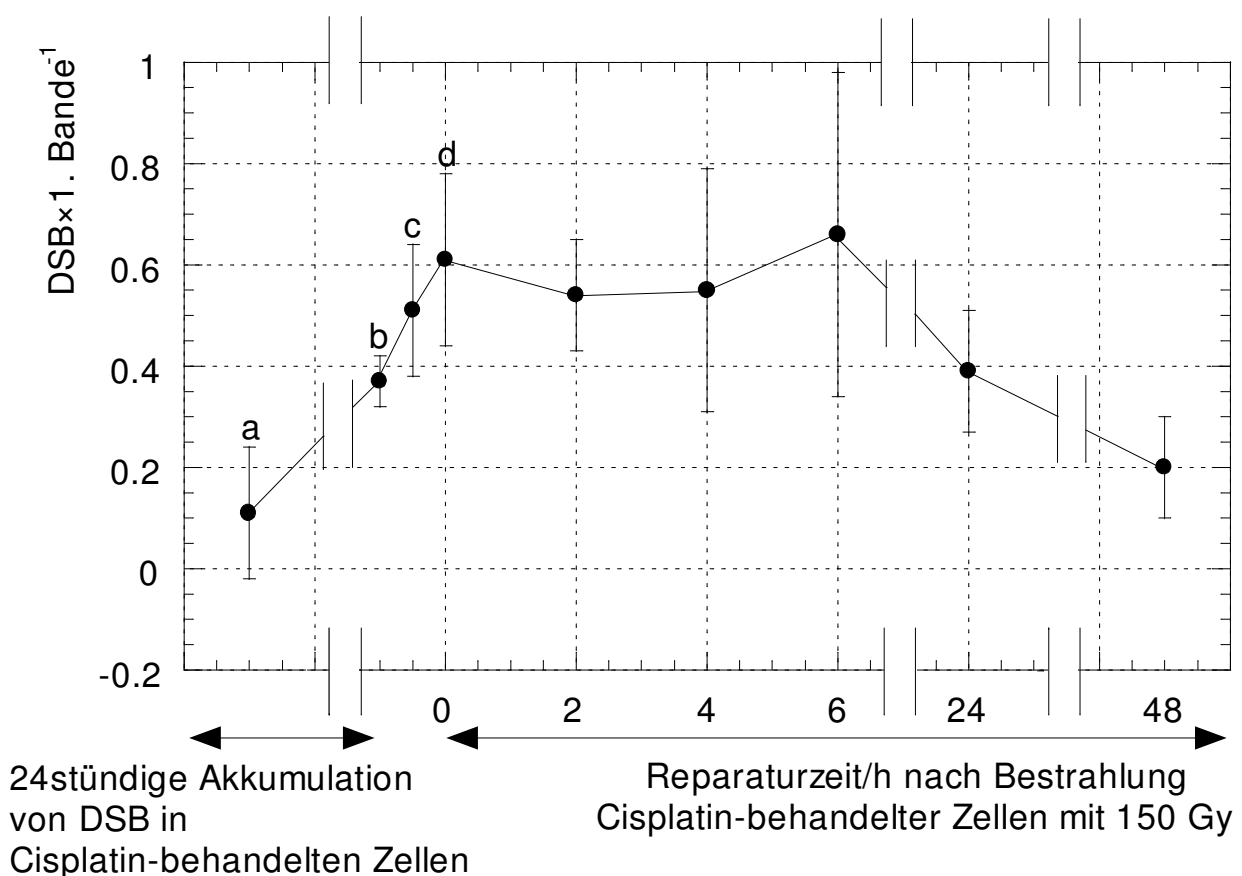

Abbildung 12: Kinetik der Reparatur von DSB nach kombinierter Behandlung der Hefemutante rad54-3 mit Cisplatin und Bestrahlung hypoxischer Zellen mit 150 Gy. Die Reparatur erfolgte unter Nichtwuchsbedingungen bei $23^{\circ} \mathrm{C}$. Die Anzahl der $\mathrm{DSB} \times 1 . \mathrm{Bande}^{-1}$ ist in Abhängigkeit von der Reparaturzeit aufgetragen. Es sind die Mittelwerte (DSB nach einstündiger Cisplatin-Behandlung bei $36^{\circ} \mathrm{C}$ (Wert a), anschließender 24stündiger Inkubation in YPD bei $36^{\circ} \mathrm{C}$ zur Akkumulation von DSB (Wert b), nachfolgender 20minütiger $\mathrm{N}_{2}$-Begasung (Wert c), Bestrahlung und Reparaturinkubation (Werte $a b$ d)) von 6 Versuchen mit den entsprechenden Standardabweichungen angegeben.

Die entsprechenden Ergebnisse der Bestrahlung Cisplatin-behandelter Zellen mit einer Dosis von 200 Gy sind in Tabelle 5 und Abbildung 13 dargestellt. 


\begin{tabular}{l|rrrrrr|r|r} 
Reparaturzeit/h & Exp. Nr. 1 & 2 & 3 & 4 & 5 & 6 & $\mathrm{x}$ & $\mathrm{s}$ \\
\hline $\mathrm{Cis}, 1 \mathrm{~h}, 36^{\circ} \mathrm{C}$ & 0,08 & 0,04 & 0,06 & 0,18 & 0,11 & 0,02 & 0,08 & 0,06 \\
$\mathrm{Cis}, 1 \mathrm{~h}, 36^{\circ} \mathrm{C}+24 \mathrm{~h}$ YPD, $36^{\circ} \mathrm{C}$ & 0,52 & 0,92 & 0,69 & 0,69 & 0,64 & 0,71 & 0,70 & 0,13 \\
Cis, $1 \mathrm{~h}, 36^{\circ} \mathrm{C}+24 \mathrm{~h} \mathrm{YPD}, 36^{\circ} \mathrm{C}+\mathrm{N}_{2}$ & 0,97 & 0,73 & 0,69 & 1,10 & 0,86 & 0,97 & 0,89 & 0,16 \\
\hline Cis + 200 Gy, Reparatur 0 h & 0,97 & 0,92 & 1,67 & 1,10 & 0,86 & 0,97 & 1,08 & 0,30 \\
Cis + $200 \mathrm{~Gy}$, Reparatur 2 h & 0,97 & 0,73 & 0,98 & 0,69 & 0,86 & 0,57 & 0,80 & 0,16 \\
Cis + 200 Gy, Reparatur 4 h & 0,84 & 0,45 & 0,83 & 0,81 & 1,00 & 0,79 & 0,79 & 0,18 \\
Cis + 200 Gy, Reparatur 6 h & 0,84 & 0,73 & 0,69 & 0,69 & 0,75 & 0,79 & 0,75 & 0,06 \\
Cis + $200 \mathrm{~Gy}$, Reparatur 24 h & & 0,44 & 0,57 & 0,75 & 0,29 & 0,69 & 0,55 & 0,19 \\
Cis + $200 \mathrm{~Gy}$, Reparatur 48 h & 0,25 & 0,03 & 0,67 & 0,44 & 0,29 & 0,37 & 0,34 & 0,21
\end{tabular}

Tabelle 5: Anzahl der DSB $\times 1$. Bande ${ }^{-1}$ nach kombinierter Behandlung der Hefemutante rad54-3 mit Cisplatin (Cis), Bestrahlung hypoxischer Zellen mit 200 Gy und anschließender Reparatur unter Nichtwuchsbedingungen bei $23^{\circ} \mathrm{C}$ (x: arithmetischer Mittelwert; s: Standardabweichung; die ersten drei Reihen zeigen die Ergebnisse nach Cisplatin-Behandlung (1.), Akkumulation von DSB in YPD bei $36^{\circ} \mathrm{C}$ (2.) und nachfolgender 20minütiger $\mathrm{N}_{2}$-Begasung (3.), die übrigen Reihen stellen die Ergebnisse der Reparatur von DSB nach kombinierter Behandlung mit Cisplatin und Bestrahlung mit 200 Gy dar). Wegen technischer Gründe (zu niedrige Zellzahlen) konnten nicht alle Ergebnisse des Experiments Nr. 1 verwendet werden. 


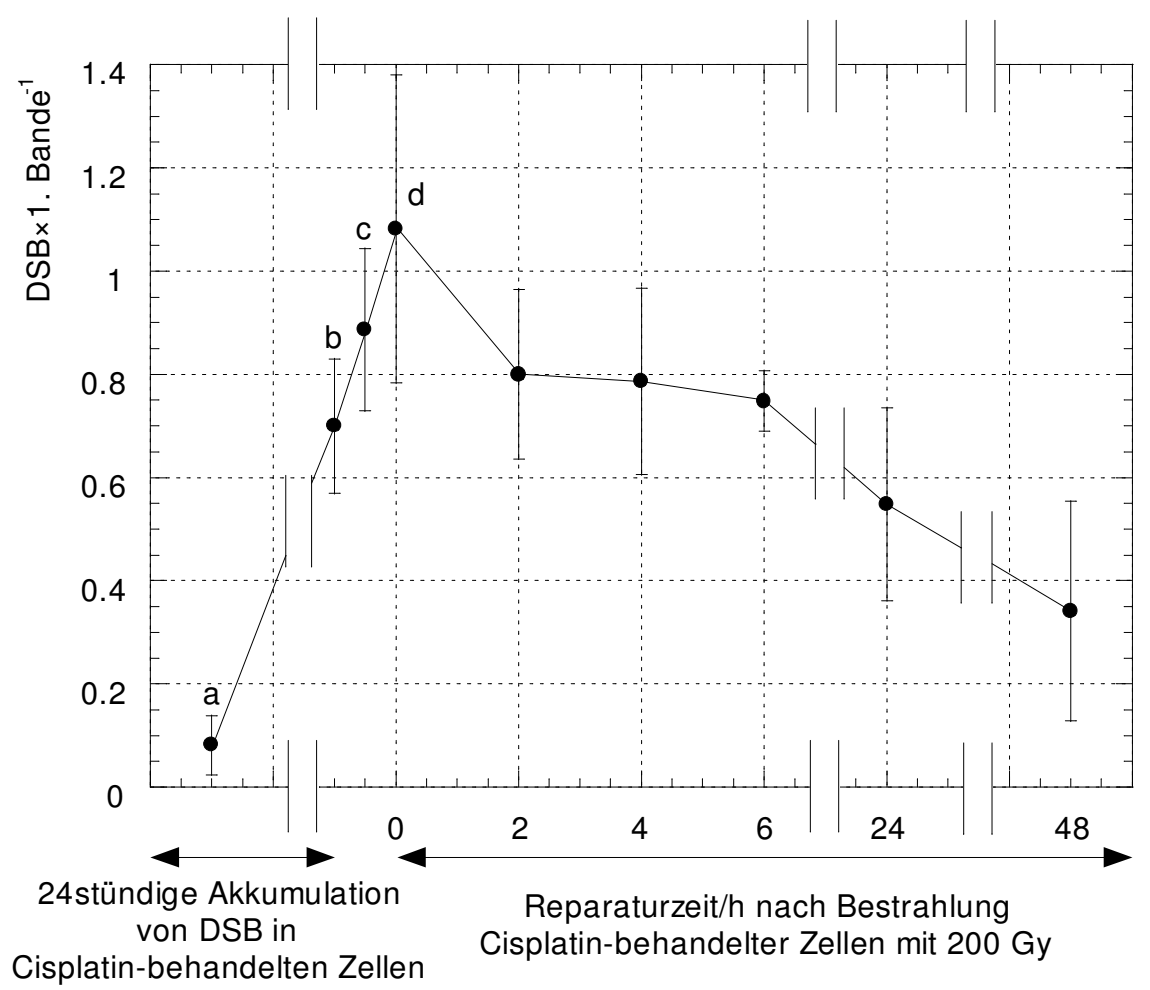

Abbildung 13: Kinetik der Reparatur von DSB nach kombinierter Behandlung der Hefemutante rad54-3 mit Cisplatin und Bestrahlung hypoxischer Zellen mit 200 Gy. Die Reparatur erfolgte unter Nichtwuchsbedingungen bei $23^{\circ} \mathrm{C}$. Die Anzahl der $\mathrm{DSB} \times 1$. Bande $^{-1}$ ist in Abhängigkeit von der Reparaturzeit aufgetragen. Es sind die Mittelwerte (DSB nach einstündiger Cisplatin-Behandlung bei $36^{\circ} \mathrm{C}$ (Wert a), anschließender 24stündiger Inkubation in YPD bei $36^{\circ} \mathrm{C}$ zur Akkumulation von DSB (Wert b), nachfolgender 20minütiger $\mathrm{N}_{2}$-Begasung (Wert c), Bestrahlung und Reparaturinkubation (Werte $a b$ d)) von 6 Versuchen mit den entsprechenden Standardabweichungen angegeben.

Bei Tabelle 5 fällt auf, dass bei den Versuchen 1, 4, 5 und 6 keine zusätzliche Induktion von DSB nach Bestrahlung im Vergleich $\mathrm{zu}$ den $\mathrm{N}_{2}$-begasten Zellen vorliegt. Das Ausgangsniveau an DSB ist bei diesen Werten bereits nach Cisplatin-Behandlung und $\mathrm{N}_{2}$-Begasung sehr hoch. Bei Berücksichtigung aller Versuche liegt der Mittelwert der Zunahme an DSB nach Bestrahlung allerdings mit 0,19 DSB $\times 1$. Bande ${ }^{-1}$ höher als nach $\mathrm{N}_{2}$-Begasung und somit im zu erwartenden Bereich (s. Abb. 8).

Wie aus den Tabellen 4-5 und den Abbildungen 12-13 hervorgeht, steigt in den Cisplatin-behandelten Zellen während der 20minütigen $\mathrm{N}_{2}$-Begasung die mittlere Zahl der DSB an, allerdings nicht wesentlich. Bei diesen Versuchen wurde die $\mathrm{N}_{2}$-Begasung 
an Zellen durchgeführt, die zuvor mit $20^{\circ} \mathrm{C}$ warmem Puffer gewaschen, dann in $20^{\circ} \mathrm{C}$ warmem Puffer suspendiert und erst während der $\mathrm{N}_{2}$-Begasung auf $4^{\circ} \mathrm{C}$ gekühlt wurden. Es liegt daher die Vermutung nahe, dass während der $\mathrm{N}_{2}$-Begasung entstandene zusätzliche DSB durch weitere enzymatische Einschnitte von Cisplatin-Addukten auf gegenüberliegenden DNA-Strängen bedingt sein könnten. Um diesen Effekt zu minimieren, wurden in den folgenden Versuchen die Zellen vor der $\mathrm{N}_{2}$-Begasung bereits mit $4^{\circ} \mathrm{C}$ kaltem Puffer gewaschen und dann in $4^{\circ} \mathrm{C}$ kaltem Puffer suspendiert.

Die Ergebnisse der Bestrahlung Cisplatin-behandelter Zellen mit einer Dosis von 300 Gy sind in Tabelle 6 und Abbildung 14 dargestellt. Sie zeigen, dass bei der kombinierten Cisplatin-Behandlung und Bestrahlung mit $300 \mathrm{~Gy}$ trotz der Verwendung von $4^{\circ} \mathrm{C}$ kaltem Puffer zum Waschen und Suspension der Zellen vor der $\mathrm{N}_{2}$-Begasung die Zahl der DSB während der $\mathrm{N}_{2}$-Begasung zunimmt, wenn auch nicht so ausgeprägt wie bei den vorherigen Versuchsreihen, in denen die Zellen erst während der $\mathrm{N}_{2}$ Begasung von $20^{\circ} \mathrm{C}$ auf $4^{\circ} \mathrm{C}$ gekühlt wurden.

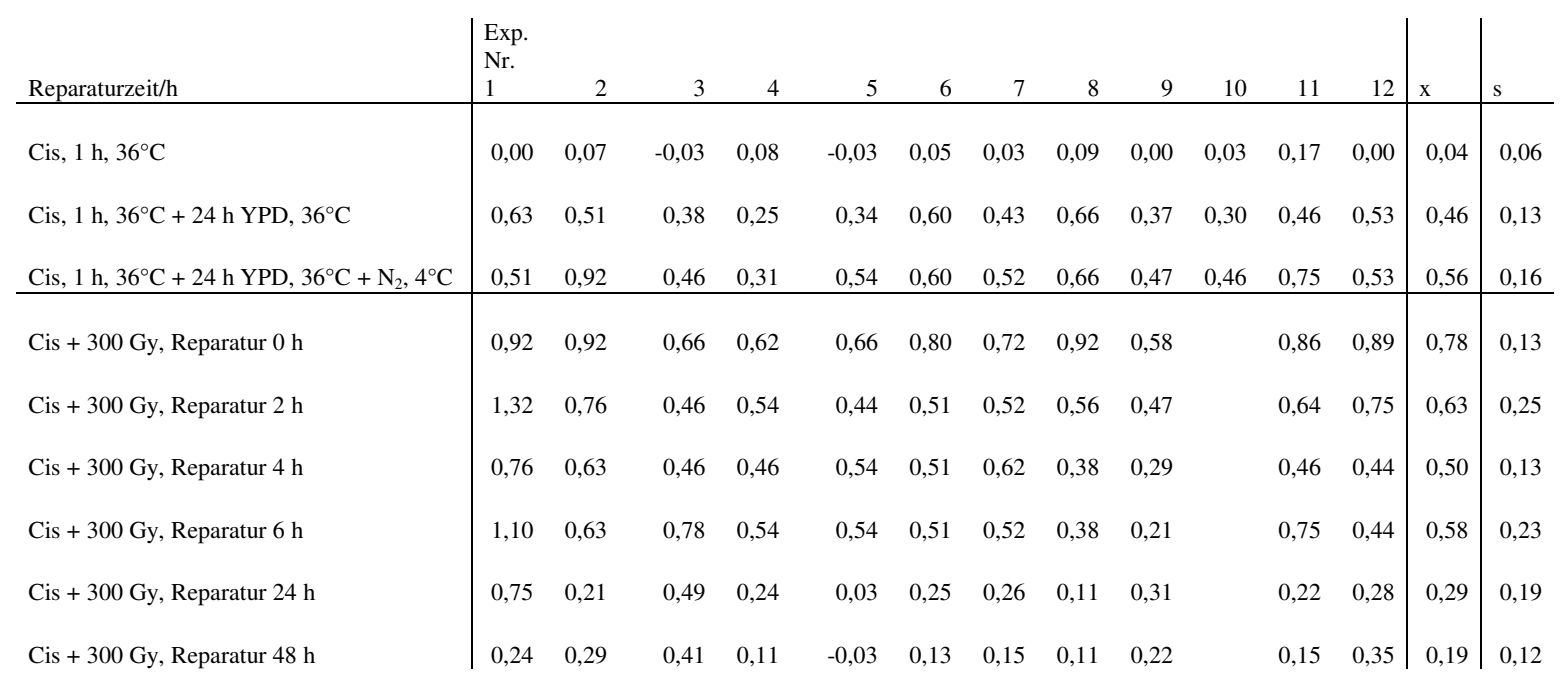

Tabelle 6: Anzahl der DSB $\times 1$. Bande ${ }^{-1}$ nach kombinierter Behandlung der Hefemutante rad54-3 mit Cisplatin (Cis), Bestrahlung hypoxischer Zellen mit 300 Gy und anschließender Reparatur unter Nichtwuchsbedingungen bei $23^{\circ} \mathrm{C}$ (x: arithmetischer Mittelwert; s: Standardabweichung; die ersten drei Reihen zeigen die Ergebnisse nach Cisplatin-Behandlung (1.), Akkumulation von DSB in YPD bei $36^{\circ} \mathrm{C}$ (2.) und nachfolgender 20minütiger $\mathrm{N}_{2}$-Begasung (3.), die übrigen Reihen stellen die Ergebnisse der Reparatur von DSB nach kombinierter Behandlung mit Cisplatin und Bestrahlung mit 300 Gy dar). Wegen technischer Gründe (zu niedrige Zellzahlen) konnten nicht alle Ergebnisse des Experiments Nr. 10 verwendet werden. 


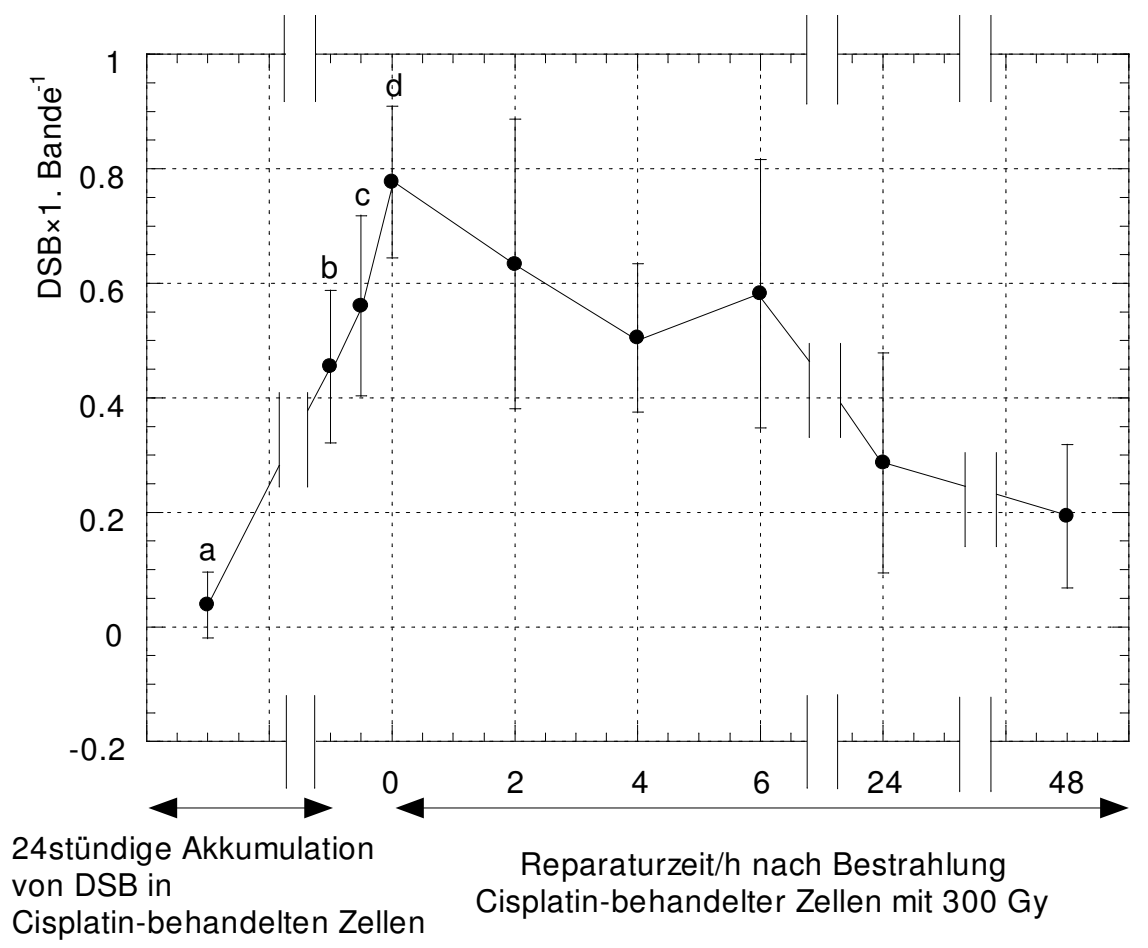

Abbildung 14: Kinetik der Reparatur von DSB nach kombinierter Behandlung der Hefemutante rad54-3 mit Cisplatin und Bestrahlung hypoxischer Zellen mit 300 Gy. Die Reparatur erfolgte unter Nichtwuchsbedingungen bei $23^{\circ} \mathrm{C}$. Die Anzahl der $\mathrm{DSB} \times 1 . \mathrm{Bande}^{-1}$ ist in Abhängigkeit von der Reparaturzeit aufgetragen. Es sind die Mittelwerte (DSB nach einstündiger Cisplatin-Behandlung bei $36^{\circ} \mathrm{C}$ (Wert a), anschließender 24 stündiger Inkubation in YPD bei $36^{\circ} \mathrm{C}$ zur Akkumulation von DSB (Wert b), nachfolgender 20minütiger $\mathrm{N}_{2}$-Begasung (Wert c), Bestrahlung und Reparaturinkubation (Werte ab d)) von 12 Versuchen mit den entsprechenden Standardabweichungen angegeben.

3.4 Auftreten von Doppelstrangbrüchen in Cisplatin-behandelten Hefezellen während der $\mathrm{N}_{2}$-Vorbegasung

Es wurden zunächst die Versuchsreihen der kombinierten Behandlung Cisplatin und Bestrahlung durchgeführt. Nach Auswertung der Ergebnisse der kombinierten Behandlung Cisplatin und Bestrahlung mit 150 Gy und 200 Gy (Tabellen 4-5 und Abbildungen 12-13) fiel auf, dass nach $\mathrm{N}_{2}$-Begasung unter Kühlung auf $4^{\circ} \mathrm{C}$ der mit $20^{\circ} \mathrm{C}$ warmem Puffer gewaschenen und suspendierten Cisplatin-behandelten Zellen zusätzliche DSB auftreten, im Mittel 0.17 DSB $\times 1$. Bande ${ }^{-1}$ (gemittelt aus Tabellen 4-5). 
Um mutmaßliche Fehlerquellen zu minimieren, wurde bei der Versuchsreihe kombinierte Behandlung mit Cisplatin und Bestrahlung mit 300 Gy die Zellen vor der $\mathrm{N}_{2}$-Begasung dagegen in $4^{\circ} \mathrm{C}$ kaltem Puffer suspendiert, daraufhin treten im Mittel nur 0.1 DSB $\times 1$. Bande ${ }^{-1}$ während der $\mathrm{N}_{2}$-Begasung auf (Tabelle 6). Die nicht Cisplatinbehandelten Zellen zeigen keinen wesentlichen Anstieg von DSB während der $\mathrm{N}_{2}$ Begasung (Tabellen 1 und 2). Dies legt die Vermutung nahe, dass die während der $\mathrm{N}_{2-}$ Begasung zusätzlich entstehenden DSB mit der vorherigen Cisplatin-Behandlung in Zusammenhang stehen und durch die Verwendung von $4^{\circ} \mathrm{C}$ vs. $20^{\circ} \mathrm{C}$ warmem Puffer teilweise, aber nicht vollständig verhindert werden können. Zur Veranschaulichung des $\mathrm{N}_{2}$-Begasungseffektes sind in Tabelle 7 die Mittelwerte der einzelnen Versuchsreihen dargestellt, wobei bei den Kombinationsversuchen die Cisplatin-bedingten, zu Beginn der $\mathrm{N}_{2}$-Begasung vorhandenen DSB abgezogen wurden. Es werden also nur die DSBWerte dargestellt, die nach der $\mathrm{N}_{2}$-Begasung bzw. nach der Bestrahlung gemessen wurden. Die erste Zeile von Tabelle 7 und Abbildung 15 zeigen den entscheidenden Einfluss der Temperatur des Puffers, in dem die Zellen suspendiert wurden.

\begin{tabular}{l|rrrrr} 
& Cis $150 \mathrm{~Gy} \#$ & $200 \mathrm{~Gy} *$ & Cis $200 \mathrm{~Gy} \#$ & $300 \mathrm{~Gy} *$ & Cis $300 \mathrm{~Gy} *$ \\
\hline $\mathrm{N}_{2}$-Begasung & 0,14 & 0,04 & 0,19 & 0,02 & 0,10 \\
$\mathrm{~N}_{2}$-Begasung + Bestrahlung & 0,24 & 0,21 & 0,38 & 0,27 & 0,32 \\
\hline Differenz & 0,10 & 0,17 & 0,19 & 0,25 & 0,22
\end{tabular}

Tabelle 7: Mittelwerte der DSB $\times 1$. Bande ${ }^{-1}$ nach $\mathrm{N}_{2}$-Begasung und Bestrahlung (\#: Temperatur des für die Suspension der Zellen verwendeten Puffers $20^{\circ} \mathrm{C}$ (Zimmertemperatur), *: Temperatur des für die Suspension der Zellen verwendeten Puffers $\left.4^{\circ} \mathrm{C}\right)$.

In Abbildung 15 werden die Werte der Tabelle 7 als Balkendiagramm abgebildet, wobei die DSB nach Bestrahlung die Gesamthöhe des Balkens ausmachen und die induzierten DSB während der $\mathrm{N}_{2}$-Begasung und Bestrahlung anteilig dargestellt sind. 


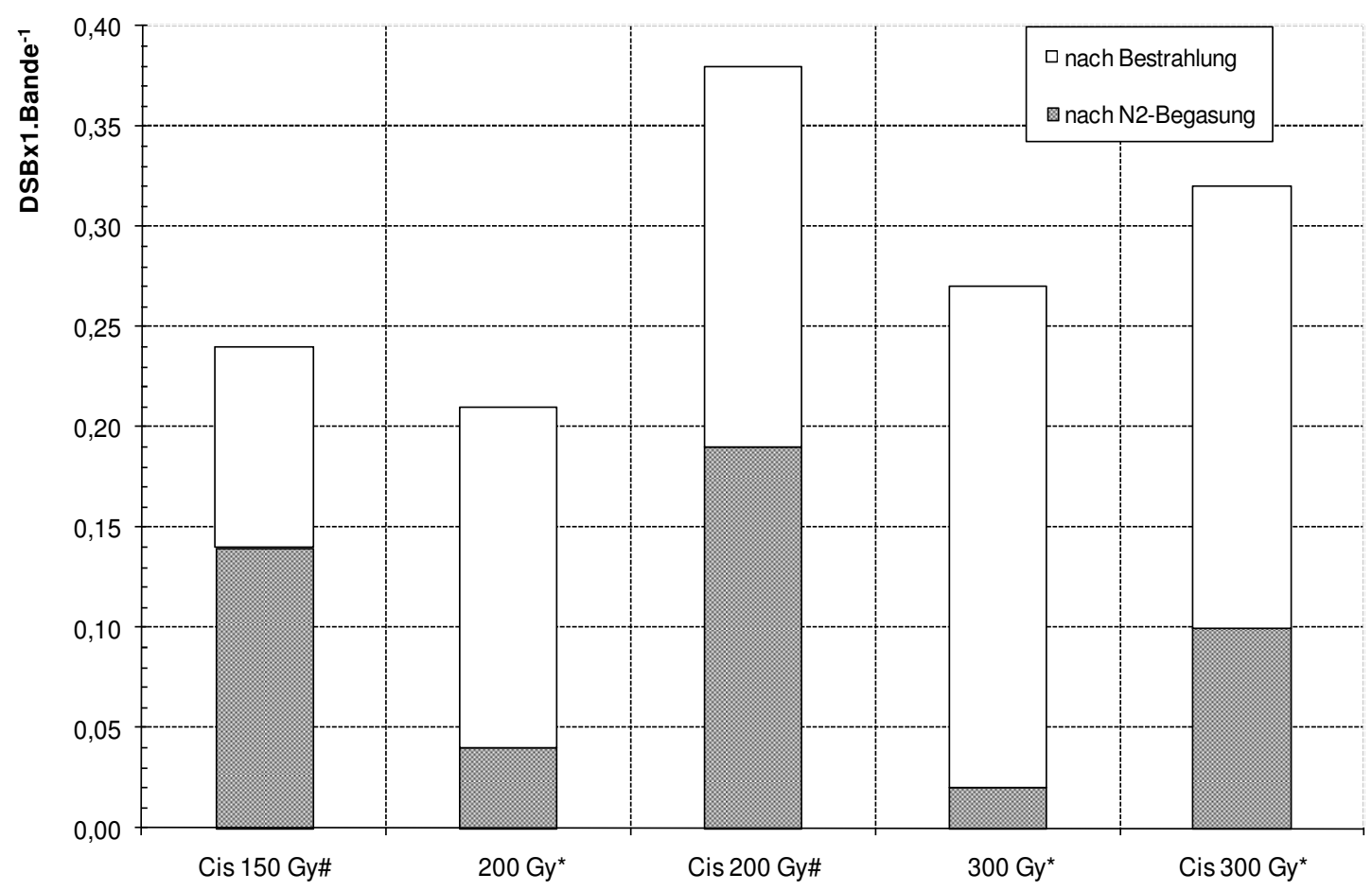

Abbildung 15: Mittelwerte der DSB $\times 1$. Bande ${ }^{-1}$, die nach der $\mathrm{N}_{2}$-Begasung bzw. nach Bestrahlung gemessen wurden in Cisplatin-vorbehandelten und nicht vorbehandelten Zellen. Um besser vergleichen zu können, wurde bei den Cisplatinvorbehandelten Zellen die Anzahl der nach 24 Stunden akkumulierten DSB abgezogen (\#: Temperatur des für die Suspension der Zellen verwendeten Puffers $20^{\circ} \mathrm{C}$ (Zimmertemperatur), *: Temperatur des für die Suspension der Zellen verwendeten Puffers $\left.4^{\circ} \mathrm{C}\right)$.

In Abbildung 15 wird deutlich, dass bei Cisplatin-behandelten Zellen während der $\mathrm{N}_{2-}$ Begasung wesentlich mehr DSB auftreten als bei nicht Cispatin-behandelten Zellen. Dieser Effekt ist ausgeprägter, wenn die Zellen für die $\mathrm{N}_{2}$-Begasung in $20^{\circ} \mathrm{C}$ warmen Puffer suspendiert wurden im Vergleich $\mathrm{zu} 4{ }^{\circ} \mathrm{C}$ kalten Puffer. Dies zeigt die Versuchsreihe Cis 300 Gy, bei der im Gegensatz zu den entsprechenden Reihen Cis 150 Gy und Cis 200 Gy die Suspension der Zellen für die $\mathrm{N}_{2}$-Begasung und Bestrahlung in $4^{\circ} \mathrm{C}$ kalten Lösungen durchgeführt wurde. 
3.5 Wirkung von Cisplatin auf Induktion und Reparatur von Doppelstrangbrüchen nach Bestrahlung hypoxischer Hefezellen

Es ist von besonderem Interesse, wie die Reparatur von DSB abläuft, wenn Zellen nach maximaler Akkumulation von Cisplatin-bedingten DSB eine Strahlendosis erhalten, so dass sich zu den Cisplatin-bedingten DSB strahleninduzierte DSB addieren. Hierzu wurde die Kinetik der Reparatur von DSB nach Kombinationsbehandlung mit Cisplatin und Bestrahlung verglichen mit der entsprechenden Kinetik nur nach Bestrahlung. Die DSB-Reparaturkinetik nach alleiniger Cisplatin-Behandlung wurde in einer anderen Arbeit untersucht (Greif 1999).

Ein Vergleich der Anzahl der bestrahlungsinduzierten DSB abzüglich der nach $\mathrm{N}_{2}$ Begasung vorliegenden DSB der Kombinationsversuche mit den Werten der reinen Bestrahlungsversuche (s. Tabelle 7) zeigt, dass eine Cisplatin-Vorbehandlung keinen wesentlichen Einfluß auf die Anzahl der strahleninduzierten DSB in hypoxischen Zellen hat. Es wurde nur die Bestrahlung an hypoxischen Zellen durchgeführt, sämtliche anderen Behandlungs- und Inkubationsschritte, insbesondere die Cisplatin-Behandlung und Akkumulation der DSB, erfolgte unter Oxie. Abbildung 16 stellt diesen Zusammenhang grafisch dar.

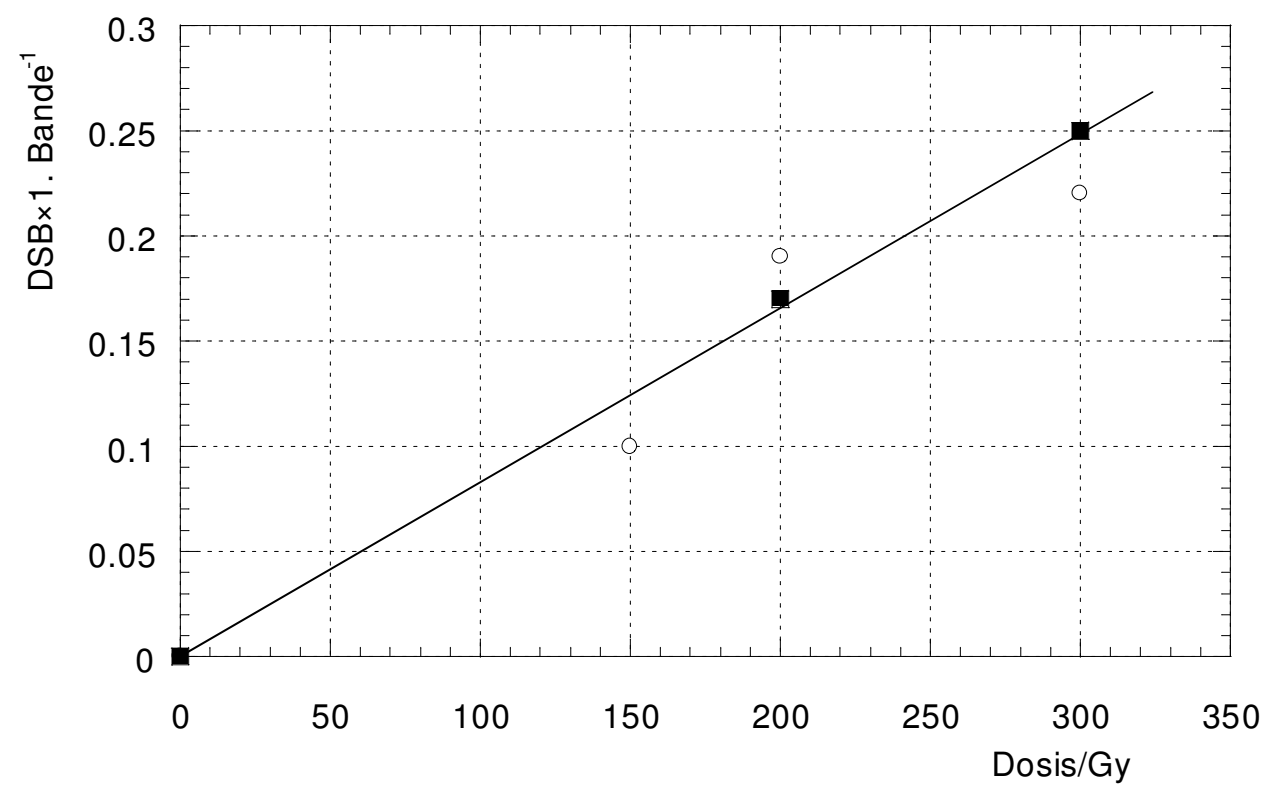

Abbildung 16: Mittelwerte der durch Bestrahlung mit 150, 200 und 300 Gy induzierten DSB $\times 1$. Bande ${ }^{-1}$ abzüglich der vorbestehenden DSB (nach $\mathrm{N}_{2}$-Begasung 
(ם), nach Cisplatin-Behandlung, 24stündiger Akkumulation von DSB und $\mathrm{N}_{2}$ Begasung $(\bigcirc)$ ).

Um die Reparaturkinetik der durch Bestrahlung alleine bzw. der durch die Kombinationsbehandlung induzierten DSB besser miteinander vergleichen zu können, wurden bei den einzelnen Versuchsreihen auf die Anzahl an DSB zum Reparaturzeitpunkt 0 h, d. h. unmittelbar nach Bestrahlung, normiert.

Abbildungen 17 und 18 stellen die relative Anzahl an DSB jeweils normiert auf den Reparaturzeitpunkt 0 Stunden der Bestrahlungsversuche mit 200 Gy bzw. 300 Gy den Kombinationsversuchen Cis 200 Gy bzw. Cis 300 Gy gegenüber. Aus den beiden Abbildungen sind keine wesentlichen Unterschiede in der Reparaturkinetik zwischen den Bestrahlungs- und den Kombinationsversuchen zu erkennen.

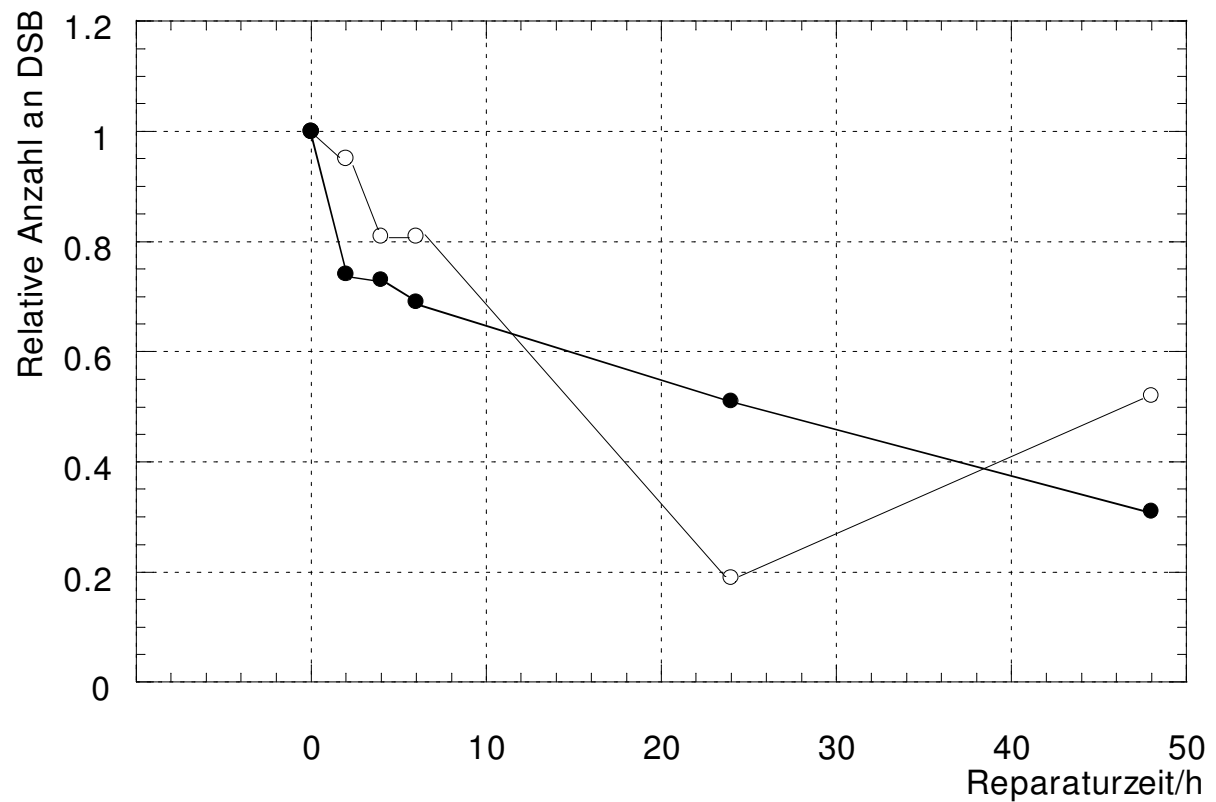

Abbildung 17: Relative Anzahl an DSB nach Normierung der DSB $\times 1$. Bande ${ }^{-1}$ der Reparaturdaten auf den Reparaturzeitpunkt 0 Stunden nach alleiniger Bestrahlung mit 200 Gy (O) bzw. in Kombination mit Cisplatin ( $)$. 


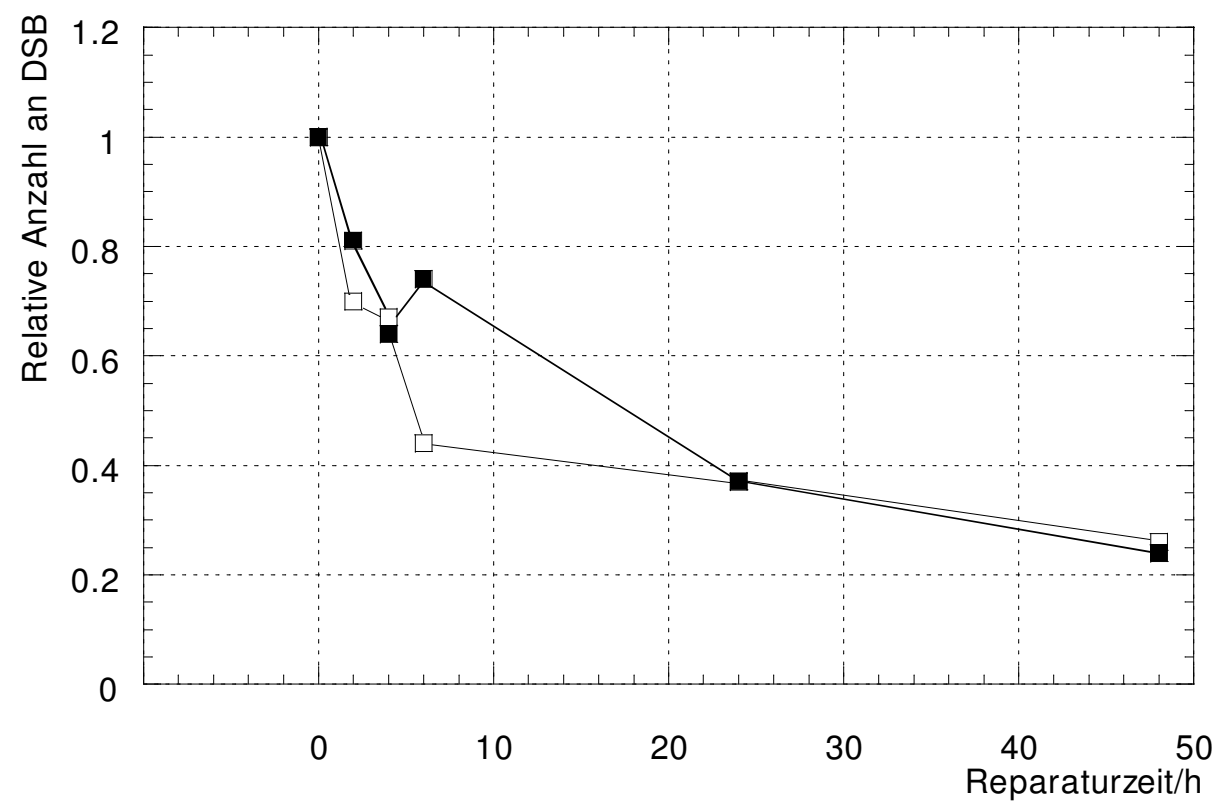

Abbildung 18: Relative Anzahl an DSB nach Normierung der Reparaturdaten auf den Reparaturzeitpunkt 0 Stunden nach alleiniger Bestrahlung mit 300 Gy ( $\square$ ) bzw. in Kombination mit Cisplatin ( $\mathbf{\square})$.

Abbildung 19 zeigt eine vergleichende Übersicht der drei Versuchsreihen Cis 150 Gy, Cis 200 Gy und Cis 300 Gy. Nach 6 Stunden fällt ein kurzfristiger Anstieg der relativen Anzahl an DSB bei der Versuchsreihe Cis 150 Gy auf, nach 24 und 48 Stunden jedoch liegen die relative Werte an verbleibenden DSB bei 40 - $60 \%$ (nach 24 Stunden) bzw. $25-35 \%$ (nach 48 Stunden) und somit bei den drei Versuchsreihen im gleichen Bereich. 


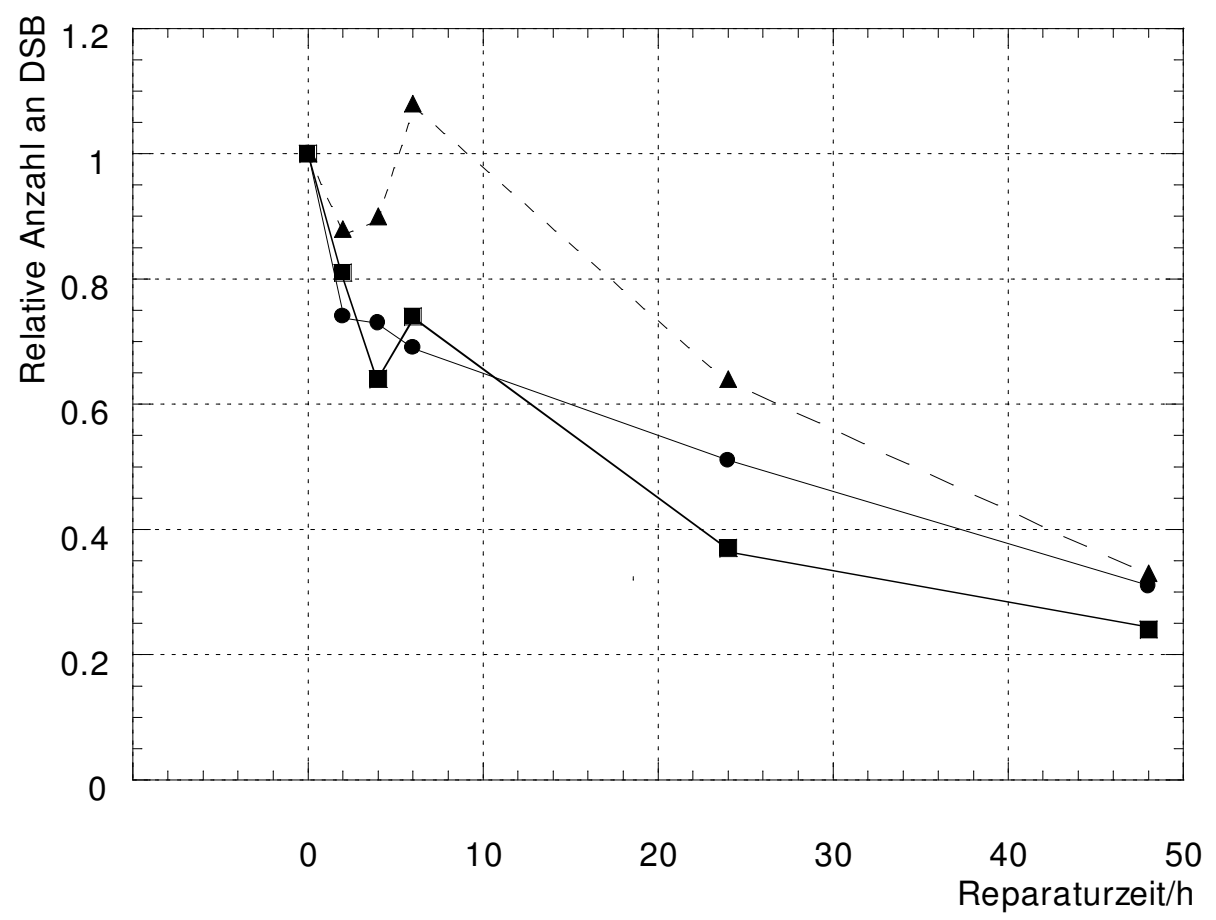

Abbildung 19: Kinetik der DSB-Reparatur nach Normierung auf den Reparaturzeitpunkt 0 Stunden der Versuchsreihen Cis 150 Gy (A), Cis 200 Gy (O) und Cis 300 Gy

\subsection{Statistischer Vergleich der Aufnahmemethoden}

Fünf Versuche der Versuchsreihe alleinige Bestrahlung mit 300 Gy wurden parallel mit beiden Aufnahmemethoden - konventionelle Fotografie und CCD-Kamera durchgeführt und mit dem Programm NIH Image ausgewertet. In Tabelle 8 werden die Messdaten der Versuche gegenübergestellt, die mit beiden Aufnahmemethoden gewonnen wurden. 


\begin{tabular}{|c|c|c|c|c|c|c|c|c|c|c|c|c|}
\hline $\begin{array}{l}\text { Reparatur- } \\
\text { zeit/h }\end{array}$ & $\begin{array}{l}\text { Exp. Nr. } \\
\text { Foto } 1 \\
\end{array}$ & CCD 1 & Foto 2 & CCD 2 & Foto 3 & CCD 3 & Foto 4 & $\mathrm{CCD} 4$ & Foto 5 & CCD 5 & Foto $\mathrm{x} \pm \mathrm{s}$ & $\mathrm{CCD} x \pm \mathrm{s}$ \\
\hline Kontrollen & 0,03 & 0,05 & 0,10 & 0,05 & 0,00 & 0,17 & 0,03 & 0,05 & $-0,03$ & 0,00 & $0,03 \pm 0,05$ & $0,06 \pm 0,06$ \\
\hline $0 \mathrm{~h}$ & 0,20 & 0,22 & 0,41 & 0,29 & 0,17 & 0,17 & 0,32 & 0,34 & 0,41 & 0,27 & $0,30 \pm 0,11$ & $0,26 \pm 0,07$ \\
\hline $2 \mathrm{~h}$ & 0,26 & 0,22 & 0,24 & 0,11 & 0,00 & 0,05 & 0,32 & 0,27 & 0,20 & 0,10 & $0,20 \pm 0,12$ & $0,15 \pm 0,09$ \\
\hline $4 \mathrm{~h}$ & 0,08 & 0,22 & $-0,03$ & 0,05 & 0,00 & 0,17 & 0,24 & 0,15 & 0,33 & 0,15 & $0,12 \pm 0,16$ & $0,15 \pm 0,06$ \\
\hline $6 \mathrm{~h}$ & 0,03 & 0,16 & 0,03 & $-0,05$ & 0,00 & 0,05 & 0,24 & 0,10 & 0,26 & 0,10 & $0,11 \pm 0,13$ & $0,07 \pm 0,08$ \\
\hline $24 \mathrm{~h}$ & $-0,03$ & 0,16 & $-0,03$ & $-0,10$ & 0,08 & 0,11 & 0,10 & 0,10 & 0,26 & 0,05 & $0,08 \pm 0,12$ & $0,06 \pm 0,10$ \\
\hline $48 \mathrm{~h}$ & 0,20 & 0,22 & 0,03 & $-0,05$ & $-0,21$ & $-0,10$ & 0,37 & 0,15 & 0,20 & 0,15 & $0,12 \pm 0,22$ & $0,07 \pm 0,14$ \\
\hline
\end{tabular}

Tabelle 8: DSB $\times 1$. Bande ${ }^{-1}$ nach Bestrahlung hypoxischer Zellen mit 300 Gy und nachfolgender Inkubation in NWM bei $23^{\circ} \mathrm{C}$ nach Aufnahme mittels konventioneller Fotografie einerseits und Aufnahme mit der CCD-Kamera andererseits (x: arithmetischer Mittelwert, s: Standardabweichung, Kontrollen: unbestrahlte Zellen nach 20minütiger Hypoxie).

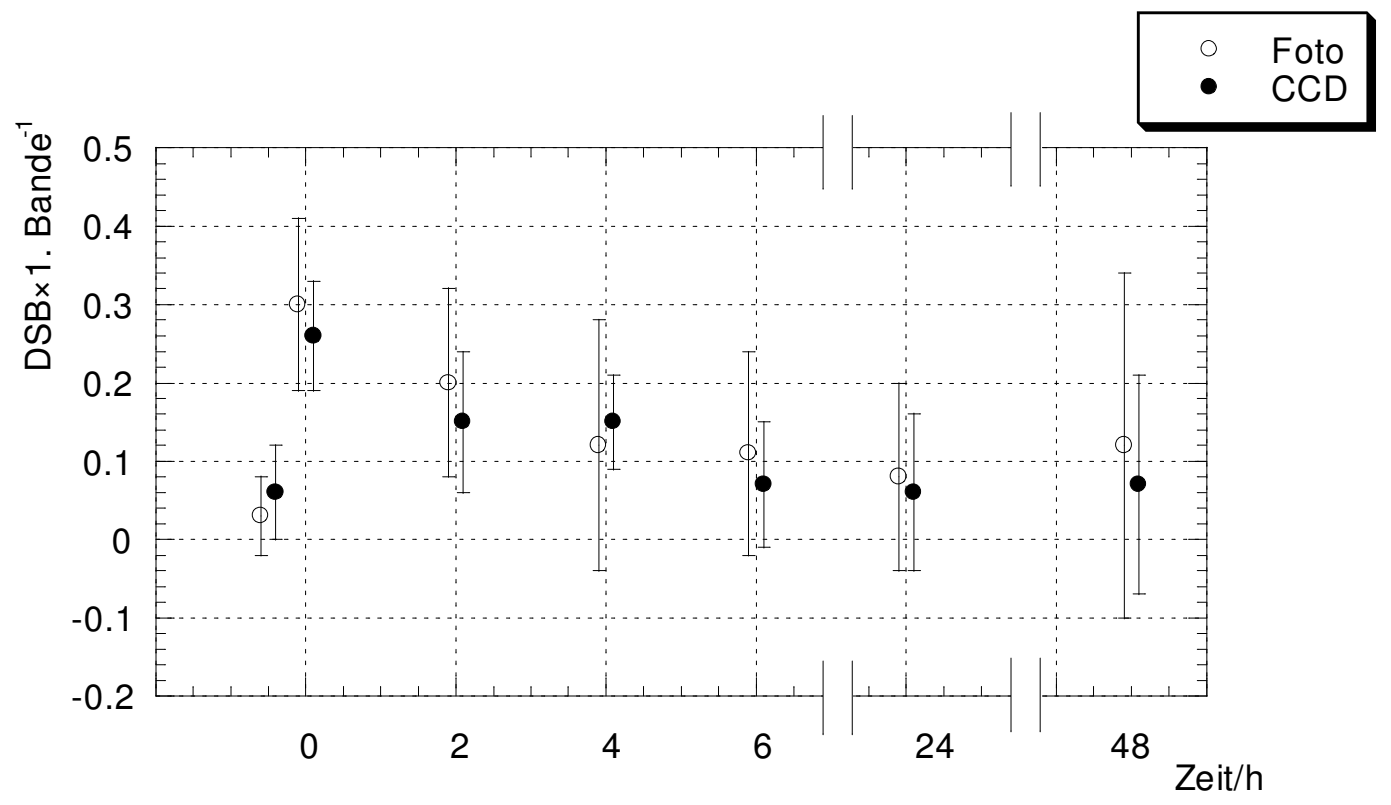

Abbildung 20: Gegenüberstellung der Reparaturkinetik von rad54-3 nach Bestrahlung hypoxischer Zellen mit 300 Gy und Inkubation in NWM bei $23^{\circ} \mathrm{C}$ nach Aufnahme mittels konventioneller Fotografie bzw. CCD-Kamera unter Darstellung von Mittelwert und Standardabweichung.

Um die Vergleichbarkeit der Daten nach Aufnahme mit den verschiedenen Methoden zu gewährleisten, wurde der Wilcoxon-Rangsummen-Test (nach Hartung et al. 1987) durchgeführt. Es zeigte sich, dass die Mittelwerte zum Signifikanzniveau $\alpha=0,2$ nicht signifikant voneinander unterschiedlich sind. Somit sind die Ergebnisse, die mit beiden 
Methoden gewonnen wurden, vergleichbar. Aus diesem Grunde war es nicht nötig, die Aufnahmemethode der einzelnen Ergebnisse speziell kenntlich zu machen.

Tabelle 8 und Abbildung 20 zeigen jedoch einen Unterschied in der Standardabweichung der Mittelwerte bei den beiden Aufnahmemethoden. Die Standardabweichungen nach Aufnahme mit konventioneller Fotografie sind größer als nach Aufnahme mit der CCD-Kamera. Dies besagt, dass zwar die Mittelwerte nach beiden Aufnahmemethoden nicht signifikant voneinander unterschiedlich sind, jedoch die Aussagekraft der mit der CCD-Kamera gewonnenen Ergebnisse wegen ihrer geringeren Streubreite größer ist. Aus diesem Grund wurden bei den Versuchen, die parallel durch beide Methoden ausgewertet wurden und deren Werte voneinander abwichen, diejenigen Werte verwendet, die mit der CCD-Kamera erzielt worden waren. 


\section{Diskussion}

4.1 Induktion und Reparatur strahleninduzierter DNA-Doppelstrangbrüche nach alleiniger Bestrahlung

Hypoxische Zellen der Hefemutante rad54-3 wurden mit Röntgenstrahlen der Dosis 200 oder $300 \mathrm{~Gy}$ bestrahlt. Hierbei entstanden im Mittel $0.21 \mathrm{DSB} \times 1$. Bande ${ }^{-1}$ bei 200 Gy und $0.27 \mathrm{DSB} \times 1$. Bande ${ }^{-1}$ bei $300 \mathrm{~Gy}$ (Abbildung 8). Ausgehend von einer linearen Beziehung zwischen der Anzahl an induzierten DSB und der einwirkenden Dosis (Abbildung 8 und Frankenberg-Schwager et al. 1979) erhält man einen Wert an DSB $\times 1$. Bande $^{-1}$ zwischen 9.0 und $10.5 \times 10^{-4} / \mathrm{Gy}$, also ca. $1 \times 10^{-3} \mathrm{DSB} \times 1$. Bande $/ \mathrm{Gy}$. Frankenberg-Schwager et al. ermittelten mittels der neutralen Sedimentationstechnik einen OER von 3,0 (1979) bzw. 2,9 (1991) für durch Bestrahlung induzierte DSB in diploiden Wildtypzellen von Saccharomyces cerevisiae. Frankenberg-Schwager et al. (1995) zeigten unter Verwendung der PFGE, dass die Anzahl der durch Bestrahlung induzierten DSB $\times 1$. Bande ${ }^{-1}$ bei Zellen der Hefemutanten rad54-3 unter Oxie bei $3.1 \times 10^{-3} \mathrm{DSB} \times 1$. Bande $\mathrm{e}^{-1}$ Gy liegt. Unter Einrechnung des oben angeführten OER von 2.9-3.0 entspricht dies einer Induktion von $1.1 \times 10^{-3} \mathrm{DSB} \times 1$. Bande $\mathrm{B}^{-1} / \mathrm{Gy}$ unter Hypoxie. Somit liegt die Induktion von DSB nach Bestrahlung unter Hypoxie, die in der vorliegenden Arbeit ebenso mittels PFGE gemessen wurde, im gleichen Bereich wie bei oben erwähnter Arbeit von Frankenberg-Schwager et al. (1995).

Die Reparatur der DSB erfolgte unter Nichtwuchsbedingungen bei $23^{\circ} \mathrm{C}$, also der Temperatur, bei der eine Reparatur der DSB durch homologe Rekombination in rad543-Zellen möglich ist. Die Reparaturkinetiken nach 200 und 300 Gy sind in Abbildungen 9 und 10 gezeigt. Die Reparaturkinetik der vorliegenden Werte zeigt eine inital schnelle Komponente, gefolgt von einer langsameren Komponente.

Für die Hefemutante rad54-3 ließen sich in der Literatur keine Halbwertszeiten für strahleninduzierte DSB finden. Hingegen gibt es bei Frankenberg-Schwager et al. (1994 c) Daten für einen Saccharomyces-cerevisiae-Stamm, der eine normale DSB-Reparatur aufweist. Hier fand sich eine initiale Halbwertszeit der DSB-Reparatur von <60 Minuten nach Bestrahlung mit $30 \mathrm{MeV}$ Elektronen unter Hypoxie und nachfolgender Inkubation in NWM. Es wird sowohl eine initial schnelle, dosisunabhängige, als auch eine langsame, dosisabhängige Reparaturkomponente beschrieben. Frankenberg-Schwager et al. fanden 1991 bei unter Hypoxie bestrahlten 
Zellen eines anderen Saccharomyces-cerevisiae-Stammes eine infolge Bildung sekundärer DSB komplexe Reparaturkinetik (Frankenberg-Schwager et al. 1991). Ein Vergleich dieser Ergebnisse mit den in dieser Arbeit gewonnenen Daten ist nicht sinnvoll, da zum einen verschiedene Saccharomyces-cerevisiae-Stämme verwendet wurden, zum anderen eine andere Inkubationstemperatur während der Reparatur vorlag und die Werte der zitierten Arbeiten für irreparable DSB korrigiert wurden.

\subsection{Induktion von Doppelstrangbrüchen durch Cisplatin-Behandlung}

In der vorliegenden Arbeit wurden direkt nach der einstündigen Cisplatin-Behandlung keine wesentilche Anzahl an DSB gemessen, im Mittel 0.1 DSB $\times 1$. Bande $^{-1}$ (Tabelle 3, Abbildung 11). Nach 24stündiger Inkubation der Zellen bei der für die DSB-Reparatur restriktiven Temperatur von $36^{\circ} \mathrm{C}$ stieg die Anzahl der DSB im Mittel auf 0.49 DSB $\times 1$. Bande $^{-1}$ an. Dieses Ergbebnis ist vergleichbar mit Daten von Frankenberg-Schwager et al. (2005), die nach Inkubation Cisplatin-behandelter Zellen in Wuchsmedium bei $36^{\circ} \mathrm{C}$ eine stetige Zunahme an DSB beobachteten, bis schließlich nach 24 Stunden ein Maximum erreicht war, welches nach weiterer Inukubation bei $36^{\circ} \mathrm{C}$ weitgehend konstant blieb. Die absoluten Werte der vorliegenden Arbeit liegen bei $0.01 \mathrm{DSB} \times 1$. Bande $^{-1}$ direkt nach Cisplatin-Behandlung und bei 0.57 DSB $\times 1$. Bande ${ }^{-1}$ nach 24stündiger Inkubation bei $36^{\circ} \mathrm{C}$. Frankenberg-Schwager veröffentlichten bereits 1988 Hefedaten, die indirekt auf eine Induktion von DSB nach Cisplatin-Behandlung hinwiesen (Frankenberg-Schwager et al. 1988 b). Ebenso konnten Wilborn und Brendel 1989 bei Wildtyp-Hefezellen nach Cisplatin-Behandlung Einzelstrangbrüche und DSB aufzeigen. Experimentell wurden DSB in Cisplatin-behandelten rad54-3-Zellen nachgewiesen, wenn deren Reparatur blockiert wurde (Frankenberg-Schwager et al. 1994 b).

Die Bildung von DSB in replizierenden Zellen innerhalb von 24 Stunden nach der Cisplatin-Behandlung unter Hemmung der DSB-Reparatur könnte durch Einschnitte an DNA-Cisplatin-Addukten bedingt sein, z. B. durch Endonukleasen des NER (= Nukleotid-Exzisions-Reparatur) -Mechanismus. Es würde sich somit nicht um primäre DSB, wie sie durch Bestrahlung induziert werden, sondern um sekundäre DSB handeln, die als Reparatur-Intermediate auftreten. Durch die Konversion von DNA-CisplatinMonoaddukten zu DNA-Cisplatin-Biaddukten können Intra- und Interstrand Crosslinks zustande kommen, hierbei liegt das Maximum der Interstrand Crosslink-Bildung bei ca. 6-12 Stunden Postinkubationszeit (Zwelling et al. 1978, Plooy et al. 1984). Sowohl an 
Cisplatin-Interstrand Crosslinks, als auch an zwei Cisplatin-Intrastrand Crosslinks, die sich zufällig an gegenüberliegenden Strängen der DNA befinden, könnten diese Einschnitte auftreten, letzteres ist allerdings wenig wahrscheinlich bei üblicherweise applizierten Cisplatin-Dosen. Somit können also vor allem Interstrand Crosslinks Anlass zur Bildung von sekundären DSB nach Cisplatin-Behandlung geben und zu dessen Toxizität beitragen, falls diese DSB nicht repariert werden. Dies kann das zeitlich verzögerte Auftreten der sekundären DSB erklären, die erst nach Inzision beider DNA-Stränge an einem Interstrand Crosslink entstehen können.

4.3 Induktion von DNA-Doppelstrangbrüchen nach $\mathrm{N}_{2}$-Begasung Cisplatinvorbehandelter Zellen

In der vorliegenden Arbeit traten während der $\mathrm{N}_{2}$-Begasung bei den Cisplatinvorbehandelten Zellen DSB auf, abhängig von der Temperatur des zur Suspension der Zellen verwendeten Puffers (Tabelle 7, Abbildung 15). Hierbei war die Anzahl an DSB bei Verwendung von Puffer der Temperatur von $20^{\circ} \mathrm{C}$ deutlich höher als bei Verwendung von $4^{\circ} \mathrm{C}$ kaltem Puffer. Die alleinige 20minütige Begasung von Zellen mit $\mathrm{N}_{2}$ kann jedoch nicht zur Induktion von DSB führen. Dies wird durch Untersuchungen in der vorliegenden Arbeit bestätigt, da bei den Bestrahlungsversuchen ohne vorherige Cisplatin-Behandlung während der $\mathrm{N}_{2}$-Begasung keine Induktion einer wesentlichen Anzahl an DSB nachzuweisen war (Tabellen 1 und 2). Es stellt sich die Frage, durch welchen Mechanismus die während der $\mathrm{N}_{2}$-Begasung entstehenden DSB gebildet werden. Am wahrscheinlichsten ist, dass dies mit der Cisplatin-Vorbehandlung zusammenhängt. Da der Effekt durch eine niedrige Puffertemperatur reduziert wird (geringere Anzahl an DSB bei Verwendung von $4^{\circ} \mathrm{C}$ vs. $20^{\circ} \mathrm{C}$ warmen Puffer), scheinen enzymatische Reaktionen eine Rolle zu spielen. Der Mechanismus, der zu einer weiteren Bildung von DSB über die bei $36^{\circ} \mathrm{C}$ akkumulierten Cisplatin-bedingten DSB hinausgeht, scheint bei $20^{\circ} \mathrm{C}$ aktiviert, bei $4^{\circ} \mathrm{C}$ teilweise gehemmt zu sein. Die Temperatur von $20^{\circ} \mathrm{C}$ wirkt nur relativ kurz während des Waschens der Zellen und vor der bei $4^{\circ} \mathrm{C}$ erfolgenden $\mathrm{N}_{2}$-Begasung ein. Unwahrscheinlich ist eine weitere Bildung von Interstrang Crosslinks, da selbst bei $36^{\circ} \mathrm{C}$ die Anzahl der DSB nicht über das Niveau ansteigt, das bereits nach 24 Stunden erreicht wurde (Frankenberg-Schwager et al. 2005). Wahrscheinlicher sind zusätzliche Inzisionen an bereits vorhandenen Interstrang Crosslinks. Eventuell könnten Proteinkomplexe eine Rolle spielen, die zur Erkennung von Cisplatin-DNA-Addukten, nachfolgenden Inzisionsvorgängen und 
schließlich zu weiteren DSB führen. Diese Proteinkomplexe könnten bei einer Temperatur von $20^{\circ} \mathrm{C}$ aktiver sein als bei $4^{\circ} \mathrm{C}$. Was die besondere Stresssituation für Cisplatin-behandelte Zellen unter $\mathrm{N}_{2}$-Begasung bei $20^{\circ} \mathrm{C}$ vs. $4^{\circ} \mathrm{C}$ ausmacht, die schließlich durch zusätzliche Inzisionen zur Bildung von DSB führt, ist nicht ganz klar. Wahrscheinlich ist jedoch, dass es sich um einen durch die vorhergehende CisplatinEinwirkung bedingten proteinabhängigen Schritt bei der Prozessierung von CisplatinDNA-Addukten handelt.

4.4 Effekt von Cisplatin auf Induktion und Reparatur strahlenbedingter DNADoppelstrangbrüche

Betrachtet man Abbildung 16 in Kapitel 3.5, so fällt auf, dass kein wesentlicher Unterschied in der Anzahl an induzierten DSB pro Bestrahlungsdosis besteht zwischen Cisplatin-vorbehandelten und nicht Cisplatin-vorbehandelten Proben. Die bestrahlungsinduzierten DSB addieren sich auf die vorbestehenden, Cisplatin-bedingten DSB. Die Cisplatin-Vorbehandlung sensibilisiert die Zellen also nicht für die Induktion von DSB durch eine folgende Bestrahlung unter hypoxischen Bedingungen.

In der Literatur zeigen sich differierende Ergebnisse bezüglich der unterschiedlichen Wirksamkeit von Cisplatin bei hypoxischen bzw. oxischen Säugerzellen. Während Stratford et al. (1980) und Matthews et al. (1993) eine bessere Wirksamkeit, d. h. eine höhere Toxizität von Cisplatin bei hypoxischen Zellen fanden, erbrachten die Untersuchungen von Teicher et al. (1990) eine bessere Wirksamkeit von Cisplatin bei oxischen Zellen. In Übereinstimmung mit den Ergebnissen der vorliegenden Arbeit berichteten Dolling et al. (1998) für humane Fibroblasten über keinen signifkanten Unterschied an induzierten DNA-Einzelstrangbrüchen nach Bestrahlung oxischer, Cisplatin-vorbehandelter Zellen im Vergleich zu Kontrollzellen.

Abbildungen 17 und 18 vergleichen die Reparaturkinetiken nach Bestrahlung mit 200 bzw. 300 Gy mit der Kombinationsbehandlung mit Cisplatin und Bestrahlung. Hier zeigt sich kein wesentlicher Unterschied in der Reparatur von DSB nach Kombinationsbehandlung im Vergleich zur Bestrahlung allein. In den Kombinationsversuchsreihen Cisplatin-Behandlung und Bestrahlung mit 150 Gy und 300 Gy wird zwar ein temporärer Anstieg an DSB nach 6 Stunden Postirradiationsinkubationszeit beobachtet, nach 24 bzw. 48 Stunden ist die relative Anzahl an nicht reparierten DSB bezogen auf die jeweils durch die Behandlung induzierten DSB nicht wesentlich voneinander unterschieden und liegt nach 48 Stunden 
bei ca. 30\%. Eine Ausnahme bildet die Versuchsreihe alleinige Bestrahlung mit $200 \mathrm{~Gy}$, bei der der Prozentsatz an nicht reparierten DSB nach 24 Stunden bei 19\% liegt und nach 48 Stunden ansteigt auf 52\%. Dies entspricht am ehesten einer Degradierung der DNA.

In der Literatur gibt es Studien zur Kombinationstherapie mit Carboplatin (einem weiteren Platin-Derivat) und Bestrahlung. Yang et al. (1995) beschrieben bei Säugerzellen eine erhöhte Anzahl an DSB nach Kombinationstherapie mit Carboplatin und Bestrahlung besonders unter Hypoxie nach einer vierstündigen Reparaturinkubation der Zellen im Vergleich zu der Anzahl an DSB sofort nach der Kombinationstherapie. Dies führte zu der Hypothese, dass Carboplatin bei der Kombinationstherapie zum einen zur Inhibition der Reparatur von strahleninduzierten DSB führt, zum anderen zum Entstehen von DSB innerhalb von vier Stunden nach der Therapie durch Exzisionsreparatur von Platin-DNA-Addukten.

Carde und Laval (1981) und Wilkins et al. (1993) beschrieben bei Säugerzellen auf Überlebensebene eine Hemmung der PLD-Reparatur nach Kombinationstherapie von Cisplatin und Bestrahlung im Vergleich zu Bestrahlung allein. Das Überleben stieg in den ersten Stunden nach Kombinationstherapie rasch an, um dann nach ca. 6-8 Stunden ein Plateau zu erreichen. Dieses Ergebnis ist vereinbar mit der vorliegenden Arbeit, die die Reparatur von DSB nach Kombinationsbehandlung von Cisplatin und Bestrahlung untersucht.

Dolling et al. (1998) untersuchten in Fibroblasten die Reparatur von DNAStrangbrüchen nach Bestrahlung mit und ohne Cisplatin-Behandlung. Sie konnten eine Inhibition der Reparatur von vorwiegend Einzelstrangbrüchen bei Kombination von Cisplatin und Bestrahlung im Vergleich zu Bestrahlung allein zeigen. Die Bestrahlung erfolgte hierbei unter oxischen Bedingungen. Das „Rejoining“ (= Zusammenführen) der DNA-Strangbrüche nach Bestrahlung ohne Cisplatin-Behandlung erfolgte in einer biphasischen Reparaturkinetik mit einer schnellen (bis 15 Minuten) und einer langsamen Reparaturkomponente (bis 90 Minuten). Bei der Vorbehandlung mit Cisplatin direkt vor der Bestrahlung war eine Hemmung der langsamen Komponente zu beobachten, bzw. eine Hemmung beider Reparaturkomponenten, wenn Cisplatin 24 Stunden vor Bestrahlung gegeben wurde. In Säugerzellen kann die Behandlung mit Cisplatin somit die Reparatur von bestrahlungsbedingten Einzelstrangbrüchen beeinträchtigen. Im Gegensatz dazu zeigen die vorliegenden Ergebnisse, dass die Induktion und Reparatur bestrahlungsbedingter DSB nicht durch eine Vorbehandlung 
mit Cisplatin beeinflusst werden. Dies mag an der unterschiedlichen Kinetik der Reparatur von Hefe- und Säugerzellen liegen.

Mehrere Studien zeigten jedoch einen radiosensibilisierenden Effekt durch eine Cisplatin-Vorbehandlung auf die Abtötung von Säugerzellen, wenn diese unter Hypoxie bestrahlt wurden vs. keinem oder nur minimalem Effekt nach Bestrahlung oxischer Zellen (Carde und Laval 1981, Melvik und Pettersen 1988, Korbelik und Skov 1989). Melvik und Pettersen (1988) fanden einen DMF (Faktor, mit dem die applizierte Strahlendosis mulitpliziert werden muss, um bei alleiniger Bestrahlung den gleichen Effekt zu erreichen) unter hypoxischen Bedingungen von 1.2. Korbelik und Skov (1989) zeigten einen für niedrige und hohe Bestrahlungsdosen unter Hypoxie unterschiedlichen DMF. Dieser lag bei hohen Bestrahlungsdosen bei 1.3 und bei niedrigen Bestrahlungsdosen ( $<4 \mathrm{~Gy}$ ) bei 2.3. Cisplatin-Vorbehandlung spielt weder für die Induktion von DSB durch Bestrahlug in hypoxischen Zellen noch für deren Reparatur eine Rolle. Es ist möglich, dass ein niedriger DMF zwar auf Überlebensebene gut messbar ist, jedoch auf der Ebene von DSB-Messungen wegen der relativ großen Standardabweichung nicht deutlich wird. Vielleicht sind für den DMF andere Schäden der DNA als DSB maßgeblich, die mit unserer Methode nicht bestimmt wurden.

\subsection{Vergleich der Auswertung mittels konventioneller Fotografie und CCD-Kamera}

Wie aus Tabelle 8 und Abbildung 19 ersichtlich, wurde in der vorliegenden Arbeit kein signifikanter Unterschied zwischen den Ergebnissen der Mittelwerte der parallel mit beiden Aufnahmemethoden (konventionelle Fotografie vs. CCD-Kamera) ausgewerteten Versuche festgestellt. Die Standardabweichung war bei Aufnahme mittels konventioneller Fotografie allerdings größer, die Reproduzierbarkeit also geringer.

1977 beschrieben Prunell et al. eine fotografische Methode, mit der die in einer Gelelektrophorese aufgetrennte DNA quantifiziert werden kann. Hierbei fanden sie, dass das Fluoreszieren der mit Ethidiumbromid gefärbten und unter UV-Licht angeregten DNA direkt proportional zu der Menge an DNA ist. Ein Artefakt bei der fotografischen Aufnahme ergibt sich daraus, dass Ethidiumbromid durch Licht (auch UV-Licht) zerfällt und somit die bei dieser Technik notwendige definierte Belichtungszeit bei zwei aufeinanderfolgenden Aufnahmen desselben Gels zu einer unterschiedlichen Intensität der Schwärzung des Films führt. Bei der quantitativen 
Messung der einzelnen DNA-Banden ist dieser Effekt aber zu vernachlässigen, da es sich um eine Relativauswertung handelt.

Obwohl eine weit verbreitete Methode, ist die Auswertung mittels fotografischer Aufnahme sehr fehleranfällig. Die vorangehende Gelelektrophorese muss in reproduzierbarer, sorgfältiger Weise durchgeführt, die Filme nach einem standardisierten Verfahren belichtet und entwickelt werden, es sollte eine hochauflösende Densitometrie zur Auswertung verwandt und entsprechende Hintergrundkontrollen zur Festlegung einer Nullinie eingesetzt werden (Ribeiro et al. 1989). Diese Grundsätze wurden bei der vorliegenden Arbeit eingehalten, gewährleistet auch dadurch, dass sämtliche Schritte des Versuchs- und Auswertungsablaufs immer von derselben Person durchgeführt wurden.

1987 wurde von Sutherland et al. die Verwendung einer CCD-Kamera zur Quantifizierung der Fluoreszenzverteilung von Elektrophoresegelen und Chromatogrammen vorgestellt. Die Vorteile der CCD-Kamera gegenüber der konventionellen Fotografie sind:

- geringerer Arbeitsaufwand (Belichtung, Entwicklung und Digitalisierung des Filmes entfallen),

- schnellere Verfügbarkeit der Daten zur Auswertung mittels Computer,

- direkte Proportionalität zwischen Fluoreszenzintensität (DNA-Gehalt) und Antwort der CCD-Kamera über einen breiten Fluoreszenzintensitätsbereich im Vergleich zur fotografischen Aufnahme, bei der eine optimale Auswertung nur in einem limitierten, nicht mehr als zwei Zehnerpotenzen umfassenden Fluoreszenzintensitätsbereich erfolgen kann.

Die Nachteile der CCD-Kamera sind teure Anschaffungskosten und die im Vergleich zur Verwendung von Film geringere Auflösung.

Freeman et al. (1990) verglichen die Auswertung mittels CCD-Kamera und konventioneller Fotografie miteinander und zeigten, dass beide Aufnahmemethoden äquivalente Ergebnisse liefern können. Die fotografische Technik kann dabei ebenso genau und reproduzierbar sein, ist allerdings stärker von der Präzision des Bedieners abhängig und somit fehleranfälliger. Deshalb kann für weitere Arbeiten die CCDKamera als Aufnahmemethode empfohlen werden, da sie, einmal angeschafft, bei einer hohen Anzahl an auszuwertenden Gelen die kostengünstigere und vor allem schnellere Alternative ist. 


\section{Zusammenfassung}

Das Chemotherapeutikum Cisplatin wurde in Kombination mit Bestrahlung in seiner Wirkung auf die Rekombinationsreparatur von DNA-Doppelstrangbrüchen in der diploiden Mutante rad54-3 der Hefe Saccharomyces cerevisiae untersucht.

Cisplatin wird allein oder in Kombination mit Bestrahlung bei der Behandlung maligner Tumorerkrankungen eingesetzt. Bei der Reaktion des Cisplatins mit der DNA entstehen über eine DNA-Monoadduktbildung bifunktionelle DNA-Addukte wie DNA-Protein-, DNA-Intrastrang und DNA-Interstrang Crosslinks. Durch zelluläre Reparaturmechanismen entstehen sekundäre DNA-Doppelstrangbrüche, die als kritische Schäden für die Zellinaktivierung gelten. Auch durch ionisierende Strahlung entstehen Doppelstrangbrüche an der DNA. In dieser Arbeit wurde die Bildung und Reparatur von Doppelstrangbrüchen nach Cisplatin-Einwirkung und Bestrahlung vs. alleinige Bestrahlung untersucht.

Methodik: Die temperaturempfindliche Hefemutante rad54-3 kann bei der restriktiven Temperatur von $36^{\circ} \mathrm{C}$ durch Ausschaltung der homologen Rekombination Doppelstrangbrüche nicht reparieren. Bei der permissiven Temperatur von $23^{\circ} \mathrm{C}$ ist die Doppelstrangbruchreparatur hingegen möglich.

In der vorliegenden Arbeit wurden Zellen der Hefemutante rad54-3 bei $36^{\circ} \mathrm{C}$ für eine Stunde mit Cisplatin behandelt und nach Auswaschen des Cisplatins für 24 Stunden in Wuchsmedium bei $36^{\circ} \mathrm{C}$ inkubiert. In vorangehenden Arbeiten wurde bereits gezeigt, dass diese Behandlung zu einer maximalen Akkumulation von Doppelstrangbrüchen führt. Dann wurden die Zellen in Nichtwuchsmedium überführt und unter hypoxischen Bedingungen mit Dosen von 150, 200 und 300 Gy bestrahlt. Die Reparaturkinetik der durch die kombinierte Behandlung entstandenen Doppelstrangbrüche wurde in Nichtwuchsmedium bei der permissiven Temperatur von $23^{\circ} \mathrm{C}$ nach $0,2,4,6,24$ und 48 Stunden untersucht und Doppelstrangbrüche mittels Pulsfeldgelektrophorese quantifiziert. Die Aufnahme der Elektrophoresegele wurde mittels konventioneller Fotografie und CCD-Kamera durchgeführt. Um die Reparaturkinetiken der Doppelstrangbrüche nach Kombinationsbehandlung von Cisplatin und Bestrahlung vs. alleiniger Bestrahlung vergleichen zu können, wurden Versuchsreihen mit alleiniger Bestrahlung mit 200 und 300 Gy hypoxischer rad54-3-Zellen durchgeführt und die Reparaturkinetik der entstandenen Doppelstrangbrüche über 48 Stunden beobachtet. 
Ergebnisse: Die Anzahl an induzierten Doppelstrangbrüchen nach Bestrahlung war dosisabhängig. Bei der Kombinationsbehandlung Cisplatin und Bestrahlung addierten sich die bestrahlungsbedingten Doppelstrangbrüche auf die Cisplatin-bedingten Doppelstrangbrüche. Es zeigte sich kein wesentlicher Unterschied in der Reparaturkinetik der Doppelstrangbrüche nach Bestrahlung von Cisplatinvorbehandelten und nicht vorbehandelten Zellen. Die relative Anzahl an nicht reparierten Doppelstrangbrüchen lag nach alleiniger Bestrahlung und nach Kombinationsbehandlung Cisplatin und Bestrahlung bei 30\%, $70 \%$ der Doppelstrangbrüche wurden repariert. Es konnte somit kein sensibilisierender Effekt der Cisplatinbehandlung für die Bestrahlung festgestellt werden. Ein überraschendes Ergebnis war die Bildung von Doppelstrangbrüchen während der 20minütigen $\mathrm{N}_{2}$ Begasung der Zellen in Cisplatin-vorbehandelten Zellen vs. keinen Effekt in nicht vorbehandelten Zellen. Diese Bildung von Doppelstrangbrüchen ließ sich durch Verwendung von $4^{\circ} \mathrm{C}$ vs. $20^{\circ} \mathrm{C}$ warmen Puffer teilweise hemmen und deutet somit auf eine Bildung von Doppelstrangbrüchen durch enzymatische Reaktionen bedingt durch die Cisplatin-Vorbehandlung hin.

Weiterhin wurden die Aufnahmemethoden (konventionelle Fotografie vs. CCDKamera) miteinander verglichen. Hierbei zeigte sich kein signfikanter Unterschied, aufgrund einer geringeren Standardabweichung bei Verwendung der CCD-Kamera und der einfacheren Handhabung empfehlen sich jedoch Aufnahmen mittels CCD-Kamera.

Schlussfolgerung: Am Modell der Hefe Saccharomyces cerevisiae als eukaryote Zelle wird anhand Induktion und Reparatur von Doppelstrangbrüchen die Wirksamkeit einer kombinierten Radio- und Chemotherapie gezeigt. Bei der kombinierten Behandlung mit Cisplatin und Bestrahlung zeigt sich zwar ein additiver, jedoch kein sensibilisierender oder potenzierender Effekt der Cisplatin-Behandlung für die Bestrahlung unter Hypoxie. Die Übertragbarkeit auf die klinische Situation ist allerdings aufgrund der verschiedenen Reparaturmechanismen von Hefe- vs. Säugerzellen begrenzt. 


\section{Literaturverzeichnis}

Abe H, Wada M, Kohno K, Kuwano M (1994): Altered drug sensitivies to anticancer agents in radiation-sensitive DNA repair deficient yeast mutants. Anticancer Res $\underline{14}$, $1807-1810$

Ager DD, Dewey WC, Gardiner K, Harvey W, Johnson RT, Waldren CA (1990): Measurement of radiation-induced DNA double-strand breaks by pulsed-field gel electrophoresis. Rad Res 122, 181-187

Andreoli TE, Bennett JC, Carpenter CCJ, Plum F: Cecil Essentials of Medicine. 4. Auflage; W. B. Saunders Company, Philadelphia/Pennsylvania 1997

Begg AC (1990): Cisplatin and radiation: interaction probabilities and therapeutic possibilities. Int J Radiat Oncol Biol Phys 19, 1189-1189

Blöcher D, Kunhi M (1990): Technical note: DNA double-strand break analysis by CHEF electrophoresis. Int J Radiat Biol $\underline{58}, 1,23-34$

Boulikas T, Vougiouka M (2004): Recent clinical trials using cisplatin, carboplatin and their combination chemotherapy drugs (review). Oncol Rep 11, 3, 559-595

Brown SJ, Kellett PJ, Lippard SJ (1993): Ixr1, a yeast protein that binds to platinated DNA and confers sensitivity to cisplatin. Science 261, 603-605

Budd M, Mortimer RK (1982): Repair of double-strand breaks in a temperature conditional radiation-sensitive mutant of Saccharomyces cerevisiae. Mutat Res $\underline{103}, 19$ 24

Carde P, Laval F (1981): Effect of cis-dichlorodiammine platinum II and X rays on mammalian cell survival. Int J Radiat Oncol Biol Phys $\underline{7}$, 929-933 
Carle GF, Olson MV (1986): An electrophoretic karyotype for yeast. Proc Natl Acad Sci USA $\underline{82}, 11,3756-3760$

Chu, G (1989): Pulsed field electrophoresis in contour-clamped homogenous electric fields for the resolution of DNA by size or topology. Electrophoresis $\underline{10}$, 290-295

Chu G (1994): Minireview: Cellular responses to cisplatin. J Biol Chem $\underline{269}$, 2, 787-790

Chu G, Vollrath D, Davis RW (1986): Separation of large DNA molecules by contourclamped homogeneous electric fields. Science $\underline{234}, 1582-1585$

Cohen SM, Lippard SJ (2001): Cisplatin: from DNA damage to cancer chemotherapy. Prog Nucleic Acid Res Mol Biol 67, 93-130

Cole RS (1971): Inactivation of Escherichia coli, $\mathrm{F}^{\prime}$ episomes at transfer, and bacteriophage lambda by psoralen plus 360-nm light: significance of deoxyribonucleic acid cross-links. J Bacteriol 107, 3, 846-852

Cole RS, Schild D, Lovett ST, Mortimer RK (1987): Regulation of RAD54- and RAD52-lacZ gene fusions in Saccharomyces cerevisiae in response to DNA damage. Mol Cell Biol ㅁ, 1078-1084

Coughlin CT, Richmond RC (1989): Biologic and clinical developments of cisplatin combined with radiation: concepts, utility, projections for new trials, and the emergence of carboplatin. Semin Oncol $\underline{16}, 31-43$

DeFazio LG, Stansel RM, Griffith JD, Chu G (2002): Synapsis of DNA ends by DNAdependent protein kinase. EMBO J 21, 12, 3192-3200

Dewit L (1987): Combined treatment of radiation and cis-diamminedichloroplatinum (II): A review of experimental and clinical data. Int J Radiat Oncol Biol Phys $\underline{13}$, 403426 
Dolling JA, Boreham DR, Brown DL, Mitchel REJ, Raaphorst GP (1998): Modulation of radiation-induced strand break repair by cisplatin in mammalian cells. Int $\mathbf{J}$ Radiat Biol 푸, 1, 61-69

Dolling JA, Boreham DR, Brown DL, Raaphorst GP, Mitchel REJ (1999): Cisplatinmodification of DNA repair and ionizing radiation lethality in yeast, Saccharomyces cerevisiae. Mutat Res $\underline{433}, 127-136$

Eastman A (1986): Reevaluation of interaction of cisDichloro(ethylenediamine)platinum(II) with DNA. Biochemistry $\underline{25}$, 3912-3915

Einhorn LH (1993): Clinical trials in testicular cancer. Cancer $\underline{71}$, 3182-3184

Emery HS, Schild D, Kellogg DE, Mortimer RK (1991): Sequence of RAD54, a Saccharomyces cerevisiae gene involed in recombination and repair. Gene 104, 103106

Fangman WL (1978): Separation of very large molecules by gel elctrophoresis. Nucleic Acids Res $\underline{5}, 653-665$

Fichtinger-Schepman AMJ, van der Veer JL, den Hartog JHJ, Lohman PHM, Reedijk J (1985): Adducts of the antitumor drug cis-Diamminedichloroplatinum(II) with DNA: formation, identification, and quantitation. Biochemistry 24 , 707-713

Fichtinger-Schepman AMJ, van Dijk-Knijnenburg HCM, van der Velde-Visser SD, Berends F, Baan RA (1995): Cisplatin- and carboplatin-DNA adducts: is Pt-AG the cytotoxic lesion? Carcinogenesis $\underline{16}, 10,2447-2453$

Frankenberg D, Frankenberg-Schwager M, Blocher D, Harbich R (1981): Evidence for DNA double-strand breaks as the critical lesions in yeast cells irradiated with sparsely or densely ionizing radiation under oxic or anoxic conditions. Radiat Res $\underline{88}, 3,524-532$

Frankenberg-Schwager M, Frankenberg D (1990): DNA double-strand breaks: their repair and relationship to cell killing in yeast. Int $\mathrm{J}$ Radiat Biol $\underline{58}, 4,569-575$ 
Frankenberg-Schwager M, Frankenberg D, Blöcher D, Adamczyk C (1979): The influence of oxygen on the survival and yield of DNA double-strand breaks in irradiated yeast cells. Int J Radiat Biol $\underline{36}, 3,261-270$

Frankenberg-Schwager M, Frankenberg D, Blöcher D, Adamczyk C (1980 a): Repair of DNA double-strand breaks in irradiated yeast cells under nongrowth conditions. Radiat Res $\underline{82}, 498-510$

Frankenberg-Schwager M, Frankenberg D, Blöcher D, Adamczyk C (1980 b): The linear relationship between DNA double-strand breaks and radiation dose (30 $\mathrm{MeV}$ electrons) is converted into a quadratic funktion by cellular repair. Int J Radiat Biol $\underline{37}$, 207-212

Frankenberg-Schwager M, Frankenberg D, Harbich R (1985): Potentially lethal damage, sublethal damage and DNA double strand breaks. Radiat Protect Dos $\underline{13}$, 171174

Frankenberg-Schwager M, Frankenberg D, Harbich R (1987): Possible occurence of DNA double-strand breaks during repair of u.v.-induced damage in yeast. Int J Radiat Biol 52, 1, 107-113

Frankenberg-Schwager M, Frankenberg D, Harbich R (1988 a): Exponential or shouldered survival curves result from repair of DNA double-strand breaks depending on irradiation conditions. Radiat Res, $\underline{114}, 54-63$

Frankenberg-Schwager M, Frankenberg D, Harbich R (1988 b): Evidence for the formation of DNA double-strand breaks in cisplatinum-treated eukaryotic cells. $7^{\text {th }}$ annual meeting of ESTRO, Den Haag, 4.-8. September

Frankenberg-Schwager M, Frankenberg D, Harbich R (1991): Different oxygen enhancement rations for induced and unrejoined DNA double-strand breaks in eukaryotic cells. Radiat Res 128, 243-250 
Frankenberg-Schwager M, Frankenberg D, Harbich R (1994 a): Radiation-induced mitotic gene conversion frequency in yeast is modulated by the conditions allowing DNA double-strand break repair. Mutat Res $\underline{314}$, 57-66

Frankenberg-Schwager M, Gebhardt D, Bär K, Frankenberg D (1994 b): Formation of DNA double-strand breaks by Cisplatinum. Radiother Oncol $\underline{32}, 67$

Frankenberg-Schwager M, Harbich R, Beckonert S, Frankenberg D (1994 c): Half-life values for DNA double-strand break rejoining vary by more than an order of magnitude depending on the irradiation conditions. Int J Radiat Biol $\underline{66}$, 5, 543-547

Frankenberg-Schwager M, Jha B, Bär K, Frankenberg D (1995): Molecular mechanism of potentially lethal damage repair. I. Enhanced fidelity of DNA double-strand break rejoining under conditions allowing potentially lethal damage repair. Int J Radiat Biol $\underline{67}, 3,277-285$

Frankenberg-Schwager M, Kirchermeier D, Greif G, Baer K, Becker M, Frankenberg D (2005): Cisplatin-mediated DNA double-strand breaks in replicating but not in quiescent cells of the yeast Saccharomyces cerevisiae. Toxicology 212, 2-3, 175-184

Fraval HNA, Roberts JJ (1979): Excision repair of cis-Diamminedichloroplatinum(II)induced damage to DNA of chinese hamster cells. Cancer Res $\underline{39}, 1793-1797$

Freeman SE, Larcom LL, Thompson BD (1990): Electrophoretic separation of nucleic acids: Evaluation by video and photographic densitometry. Electrophoresis 11, 425-431

Fu KK: Interactions of chemotherapeutic agents and radiation; in: Frontiers of Radiation Therapy and Oncology, Band 26: Radiotherapy/Chemotherapy Interactions in Cancer Therapy; hrsg. v. Meyer JL, Vaeth JM; Karger, Basel 1992, 16-30

Game JC, Cox BS (1971): Allelism tests of mutants affecting sensitivity to radiation in yeast and a proposed nomenclature. Mutat Res $\underline{12}, 328-331$ 
Game JC, Mortimer RK (1974): A genetic study of X-ray sensitive mutants in yeast. Mutat Res $\underline{24}, 281-292$

Greif G: Experimentelle Untersuchungen über die Kinetik der Reparatur von DNSDoppelstrangbrüchen nach Cisplatin-Behandlung in der Hefe Saccharomyces cerevisiae. Med. Diss. Göttingen 1999

Haber JE (1999): DNA reombination: the replication connection. Trends Biochem Sci $\underline{24}, 271-275$

Hannan MA, Zimmer SG, Hazle J (1984): Mechanisms of cisplation (cisdiamminodichloroplatinum II)-induced cytoxicity and genotoxicity in yeast. Mutat Res $\underline{127}, 23-30$

Hartenstein R, Clemm CH: Hodenkarzinome; in: Medikamentöse Therapie maligner Erkrankungen; hrsg. v. Huhn D und Herrmann R; Fischer Verlag, Stuttgart 1995, 337 355

Hartung J, Elpelt B, Kloesener KH: Statistik: Lehr- und Handbuch der angewandten Statistik. 6. Auflage; Oldenbourg Verlag, München 1987

Ho KSY (1975): Induction of DNA double-strand breaks by X-rays in a radiosensitive strain of the yeast Saccharomyces cerevisae. Mutat Res $\underline{30}$, 327-334

Hughes EN, Engelsberg BN, Billings PC (1992): Purification of nuclear proteins that bind to cisplatin-damaged DNA. J Biol Chem 267, 19, 13520-13527

Jones JC, Zhen W, Reed E, Parker RJ, Sancar A, Bohr VA (1991): Gene-specific formation and repair of cisplatin intrastrand adducts and interstrand cross-links in chinese hamster ovary cells. J Biol Chem $\underline{266}, 11,7101-7107$

Kasparkova J, Pospisilova S, Brabec V (2001): Different recognition of DNA modified by antitumor cisplatin and its clinically ineffective trans isomer by tumor suppressor protein p53. J Biol Chem, 276, 19, 16064-16069 
Köpf-Maier P, Köpf H (1986): Cytostatische Platin-Komplexe: eine unerwartete Entdeckung mit weitreichenden Konsequenzen. Naturwissenschaften $\underline{73}$, 239-247

Korbelik M, Skov KA (1989): Inactivation of hypoxic cells by cisplatin and radiation at clinically relevant doses. Radiat Res $\underline{119}$, 145-156

Krebs in Deutschland: 5. überarbeitete, aktualisierte Ausgabe. Gesellschaft der epidemiologischen Krebsregister in Deutschland e. V. und das RKI, Saarbrücken 2006

Lauer GD, Roberts TM, Klotz LC (1977): Determination of the nuclear DNA content of Saccaromyces cerevisae and implications for the organization of DNA in yeast chromosomes. J Mol Biol 114, 507-526

Leng M, Locker D, Giraud-Panis MJ, Schwartz A, Intini FP, Natile G, Pisano C, Boccarelli A, Giordano D, Coluccia M (2000): Replacement of an $\mathrm{NH}_{3}$ by an iminoether in transplatin makes an antitumor drug from an inactive compound. Mol Pharmacol $\underline{58}, 6,1525-1535$

Leuther KK, Hammarsten O, Kornberg RD, Chu G (1999): Structure of DNAdependent protein kinase: implications for its regulation by DNA. EMBO J $\underline{18}, 5,1114-$ 1123

Lippert B (1996): Trans-diammineplatinum(II): What makes it different from cis-DDP? Coordination chemistry of a neglected relative of cisplatin and its interaction with nucleic acids. Met Ions Biol Syst $\underline{33}, 105-142$

Lissner J, Fink U (1992): Radiologie I. 4. Auflage; Ferdinand Enke Verlag, Stuttgart

Los G, van Vugt MJH, den Engelse L, Pinedo HM (1993): Effects of temperature on the interaction of cisplatin and carboplatin with cellular DNA. Biochem Pharmacol $\underline{46}, 7$, 1229-1237 
Matthews JB, Adomat H, Skov KA (1993): The effect of hypoxia on cytotoxicity, accumulation and DNA binding of cisplatin in Chinese hamster ovary cells. Anticancer Drugs $\underline{4}, 463-470$

McA Nulty MM, Lippard SJ (1996): The HMG-domain protein Ixr1 blocks excision repair of cisplatin-DNA adducts in yeast. Mutat Res $\underline{362}, 75-86$

McA Nulty MM, Whitehead JP, Lippard SJ (1996): Binding of Ixr1, a yeast HMGdomain protein, to cisplatin-DNA adducts in vitro and in vivo. Biochemistry $\underline{35}, 6089$ 6099

Melvik JE, Pettersen EO (1988): Oxygen- and temperature-dependent cytotoxic and radiosensitizing effects of cis-dichlorodiammineplatinum(II) on human NHIK 3025 cells in vitro. Radiat Res 114 , 489-499

Mirabelli CK, Huang CH, Fenwick RG, Crooke ST (1985): Quantitative measurement of single- and double-strand breakage of DNA in Escherichia coli by the antitumor antibiotics bleomycin and talisomycin. Antimicrob Agents Chemother 27, 460-467

Mortimer RK, Contopoulou CR, King JS (1992): Genetic and physical map of Saccharomyces cerevisae, Edition 11 . Yeast $\underline{8}, 10,817-902$

Osman F, Subramani S (1998): Double-strand break-induced recombination in eucaryotes. Prog Nucleic Acid Res Mol Biol 툐, 263-299

Pâques F, Haber JE (1999): Multiple pathways of recombination induced by doublestrand breaks in Saccharomyces cerevisiae. Microbiol Mol Biol Rev $\underline{63}$, 2, 349-404

Patrick SM und Turchi JJ (1998): Human replication protein A preferentially binds cisplatin-damaged duplex DNA in vitro. Biochemistry $\underline{37}, 8808-8815$

Pera Jr. MF, Rawlings CJ, Roberts JJ (1981): The role of DNA repair in the recovery of human cells from cisplatin toxicity. Chem Biol Interact 37, 245-261 
Pinto AL, Lippard SJ (1985): Sequence-dependent termination of in vitro DNA synthesis by cis- and trans-diamminedichloroplatinum(II). Proc Natl Acad Sci USA $\underline{82}$, $14,4616-4619$

Plooy AC, van Dijk M, Lohmann PH (1984): Induction and repair of DNA cross-links in chinese hamster ovary cells treated with various platinum coordination compounds in relation to platinum binding to DNA; cytotoxicity, mutagenicity, and antitumor activity. Cancer Res $\underline{44}$, 2043-2051

Prunell A, Strauss F, Leblanc B (1977): Photographic quantitation of DNA in gel electrophoresis. Tical Biochem $\underline{78}, 57-65$

Resnick MA, Martin P (1976): The repair of double-strand breaks in the nuclear DNA of Saccharomyces cerevisae and its genetic control. Mol Gen Genet 143, 119-129

Ribeiro EA., Larcom LL, Miller DP (1989): Quantitative fluorescence of DNAintercalated ethidium bromide on agarose gels. Anal Biochem $\underline{181}, 197-208$

Riede UN, Schaefer HE: Allgemeine und spezielle Pathologie. 3. Auflage; Georg Thieme Verlag, Stuttgart 1993

Rosenberg B, VanCamp L, Trosko JE, Mansour VH (1969): Platinum compounds: a new class of potent antitumour agents. Nature 222, 385-386

Saeki T, Machida I, Nakai S (1980): Genetic control of diploid recovery after gammairradiation in the yeast Saccharomyces cerevisae. Mutat Res $\underline{73}$, 2, 251-265

Sancar A, Sancar GB (1988): DNA repair enzymes. Ann Rev Biochem 57, 29-67

Schwartz DC, Cantor CR (1984): Separation of yeast chromosome-sized DNA molecules by pulsed field gradient gel electrophoresis. Cell $\underline{37}, 67-75$ 
Sherman SE, Gibson D, Wang AHJ, Lippard SJ (1985): X-ray structure of the major adduct of the anticancer drug cisplatin with DNA: cis-[Pt( $\left.\left.\mathrm{NH}_{3}\right)_{2}\{\mathrm{~d}(\mathrm{pGpG})\}\right]$. Science $\underline{230}, 412-417$

Skov KA: The interaction of platinum complexes with low doses of x-rays in hypoxic cells: possible role of crosslinks; in: Low dose irradiation and biological defense mechanisms; hrsg. v. Sugahara T, Sagan LA, Aoyama T; Elsevier Science Publishers B. V., Kyoto 1992, 367-370

Stratford IJ, Williamson C, Adams GE (1980): Combination studies with misonidazole and a cis-platinum complex: cytotoxicity and radiosensitization in vitro. Br J Cancer $\underline{41}$, $517-522$

Sutherland JC, Lin B, Monteleone DC, Mugavero J, Sutherland BM, Trunk J (1987): Electronic imaging system for direct and rapid quantitation of fluorescence from elctrophoretic gels: Application to ethidium bromide-stained DNA. Anal Biochem 163, 446-457

Teicher BA, Holden SA, Al-Achi A, Herman TS (1990): Classification of antineoplastic treatments by their differential toxicity toward putative oxygenated and hypoxic tumor subpopulations in vivo in the FSaIIC murine fibrosarcoma. Cancer Res $\underline{50}$, 3339-3344

Turchi JJ, Henkels KM (1996): Human Ku autoantigen binds cisplatin-damaged DNA but fails to stimulate human DNA-activated protein kinase. J Biol Chem 271, 23, 13861-13867

Turchi JJ, Li M, Henkels KM (1996): Cisplatin-DNA binding specificity of calf high mobility group 1 protein. Biochemistry $\underline{35}, 2992-3000$

Turchi JJ, Patrick SM, Henkels KM (1997): Mechanism of DNA-dependent protein kinase inhibition by cis-diamminedichloroplatinum(II)-damaged DNA. Biochemistry $\underline{36}, 7586-7593$ 
Turchi JJ, Henkels KM, Zhou Y (2000): Cisplatin-DNA adducts inhibit translocation of the Ku subunits of DNA-PK. Nucleic Acids Res $\underline{28}$, 23, 4634-4641

Verly WG, Brakier L (1969): The lethal action of monofunctional and bifunctional alkylating agents on T7 coliphage. Biochim Biophys Acta 174, 674-685

Vollrath D: Resolving multimegabase DNA molecules using contour-clamped homogenous electric fields (CHEF); in: Methods in Molecular Biology, Band 12: Pulsed-Field Gel Electrophoresis; hrsg. v. Burmeister M, Ulanovsky L; The Humana Press, Totowa/NJ 1992, 19-30

Werner-Washburne M, Braun EL, Crawford ME, Peck VM (1996): MicroReview: Stationary phase in Saccharomyces cerevisae. Mol Microbiol 19, 6, 1159-1166

Wilborn F, Brendel M (1989): Formation and stability of interstrand cross-links induced by cis- and trans-diamminedichloroplatinum (II) in the DNA of Saccharomyces cerevisiae strains differing in repair capacity. Curr Genet 16, 5-6, 331-338

Wilkins DE, Heller DP, Raaphorst GP (1993): Inhibition of potentially lethal damage recovery by cisplatin in a brain tumor cell line. Anticancer Res $\underline{13}, 2137-2142$

Wold MS (1997): Replication protein A: a heterotrimetric, single-stranded DNAbinding protein required for eukaryotic DNA metabolism. Annu Rev Biochem $\underline{66}$, 6192

Yang L, Douple EB, O`Hara JA, Wang HJ (1995): Production of DNA double-strand breaks by interactions between carboplatin and radiation: a potential mechanism for radiopotentiation. Radiat Res $\underline{143}$, 309-315

Zwelling LA, Kohn KW, Ross WE, Ewig RA, Anderson T (1978): Kinetics of formation and disappearance of a DNA cross-linking effect in mouse leukemia L1210 cells treated with cis- and trans-diamminedichlororplatinum(II). Cancer Res $\underline{38}$, 17621768 